

Special Issue-Irregular Migrants, Refugees or Trafficked Persons?

Editorial: Categorising Migrants: Standards, complexities, and politics

Smuggled or Trafficked? Refugee or job seeker? Deconstructing rigid classifications by rethinking women's vulnerability

Seeing Migration like a State: The case of irregular Indonesian migrant workers deported from Malaysia

Refugees or Victims of Human Trafficking? The case of migrant domestic workers in Hong Kong

Addressing Overlapping Migratory Categories within New Patterns of Mobility in Peru

'What's in a Name?': Mislabelling, misidentification, and the US government's failure to protect human trafficking survivors in the Central American refugee crisis

'Circuit Children': The experiences and perspectives of children engaged in migrant smuggling facilitation on the US-Mexico border

Debate: 'It is important and necessary to make clear distinctions between (irregular) migrants, refugees and trafficked persons'

Migrants, Irregular Migrants, or (Irregular) Migrants?

The Antics of Semantics in International Law

Words Matter. But Rights Matter More

Call Me by My Name 




GUEST EDITORS

CLAUS K. MEYER

EDITOR

SEBASTIAN BOLL

BORISLAV GERASIMOV

EDITORIAL BOARD

RUTVICA ANDRIJASEVIC, University of Bristol, United Kingdom

LYNDSEY BEUTIN, Oberlin College, United States

JACQUELINE BHABHA, Harvard School of Public Health, United States

URMILA BHOOLA, UN Special Rapporteur on contemporary forms of slavery,

including its causes and consequences, South Africa

XIANG BIAO, Oxford University, United Kingdom

LUCIANA CAMPELLO, Panamerican Health Organization, Brazil

JOY NGOZI EZEILO, University of Nigeria; Former UN Special Rapporteur on trafficking

in persons, especially women and children, Nigeria

ANNE T. GALLAGHER, Independent scholar and legal advisor, Australia

JOHN GEE, Transient Workers Count Too, Singapore

CHANDRE GOULD, Institute for Security Studies, South Africa

YANA HASHAMOVA, Ohio State University, United States

SUZANNE HOFF, La Strada International, The Netherlands

KRISTIINA KANGASPUNTA, United Nations Office on Drugs and Crime, Austria

KAMALA KEMPADOO, York University, Canada

ANNALEE LEPP, University of Victoria, Canada

MARIKA WEN MCADAM, Independent Consultant, Australia

SVERRE MOLLAND, Australian National University, Australia

REBECCA NAPIER-MOORE, Independent Consultant, Thailand

MARINA NOVAES, Secretariat of Human Rights and

Citizenship of Sao Paulo's City Hall, Brazil

VICTORIA IJEOMA NWOGU, United Nations Development Programme, Somalia

JULIA O'CONNELL DAVIDSON, University of Bristol, United Kingdom

PIA OBEROI, Office of the High Commissioner for Human Rights, Switzerland

SAM OKYERE, University of Nottingham, United Kingdom

ELAINE PEARSON, Human Rights Watch, Australia

NICOLA PIPER, University of Sydney, Australia

NIVEDITA PRASAD, Alice Salomon University of Applied Sciences, Germany

CAROLINE ROBINSON, Focus on Labour Exploitation, United Kingdom

JYOTI SANGHERA, Office of the High Commissioner for Human Rights, Switzerland

MARIE SEGRAVE, Monash University, Australia

ELENA SHIH, Brown University, United States

KENDRA STRAUSS, Simon Fraser University, United States

REBECCA SURTEES, NEXUS Institute, United States

SALLIE YEA, Independent scholar and consultant, Australia

CATHY ZIMMERMAN, London School of Hygiene and Tropical Medicine, United Kingdom 


\section{ANTI-TRAFFICKING REVIEW}

Special Issue

IRREGULAR MIGRANTS, REFUGEES OR TRAFFICKED PERSONS?

The Anti-Trafficking Review (ISSN 2286-7511) is published by the Global Alliance Against Traffic in Women (GAATW), a network of over 80 NGOs worldwide focused on advancing the human rights of migrants and trafficked persons.

The Anti-Trafficking Review promotes a human rights-based approach to anti-trafficking. It explores trafficking in its broader context including gender analyses and intersections with labour and migration. It offers an outlet and space for dialogue between academics, practitioners, trafficked persons and advocates seeking to communicate new ideas and findings to those working for and with trafficked persons.

The Review is primarily an e-journal, published biannually. The journal presents rigorously considered, peer-reviewed material in clear English. Each issue relates to an emerging or overlooked theme in the field of anti-trafficking.

Articles contained in the Review represent the views of the respective authors and not necessarily those of the editors, the Editorial Board, the GAATW network or its members. The editorial team reserves the right to edit all articles before publication. 
The Anti-Trafficking Review is an open access publication distributed under the terms of the Creative Commons Attribution License (CC-BY).

The Anti-Trafficking Review promotes the sharing of information, and we therefore encourage the reproduction and onward dissemination of articles published with us. 


\section{ANTI-TRAFFICKING REVIEW}

Issue 11, October 2018

Editorial: Categorising Migrants: Standards, complexities, and politics

Claus K. Meyer and Sebastian Boll

Thematic Articles: Irregular Migrants, Refugees or Trafficked Persons?

16 Smuggled or Trafficked? Refugee or job seeker? Deconstructing rigid classifications by rethinking women's vulnerability Giorgia Serughetti

36 Seeing Migration like a State: The case of irregular Indonesian migrant workers deported from Malaysia Benny Hari Juliawan

52 Refugees or Victims of Human Trafficking? The case of migrant domestic workers in Hong Kong Jade Anderson and Annie Li

69 Addressing Overlapping Migratory

Categories within New Patterns of Mobility in Peru

\section{Cécile Blouin and Emily Button}

'What's in a Name?': Mislabelling, misidentification, and the US government's failure to protect human trafficking survivors in the Central American refugee crisis

Katherine Soltis and Rebecca Walters 
103 'Circuit Children': The experiences and perspectives of children engaged in migrant smuggling facilitation on the US-Mexico border

Gabriella Sanchez

Debate: 'It is important and necessary to make clear distinctions between (irregular) migrants, refugees and trafficked persons'

121 Migrants, Irregular Migrants, or (Irregular) Migrants?

Katharine T. Weatherhead

125 The Antics of Semantics in International Law

Marika McAdam

129 Words Matter. But Rights Matter More Pia Oberoi

133 Call Me by My Name Sarah Elliott 


\title{
Editorial: Categorising Migrants: Standards, complexities, and politics
}

\author{
Claus K. Meyer and Sebastian Boll
}

Please cite this article as: C K Meyer and S Boll, 'Editorial: Categorising Migrants: Standards, complexities, and politics', Anti-Trafficking Review, issue 11, 2018, pp. 1-14, www.antitraffickingreview.org

In spring 2017, New York Times correspondent Patrick Kingsley went to Turkey to cover the lives of Syrian refugees. ${ }^{1}$ In Istanbul, Kingsley met Abu Mohammed, a former surgeon's assistant from Syria, who between 2015 and 2016 had helped to facilitate the passage of refugees from his home country into Greece. After narrowly escaping death in his own failed attempt to reach Europe, Mohammed had earned some USD 800,000 with 'smuggling' activities. He himself spoke of a 'dirty business', but it had also been more than just a business - the refugees whom he had helped reach Europe included relatives and even his own son.

Kingsley also met 15-year-old Syrian Ismail Alanzi, a refugee working 'up to 11 hours a day, six days a week' on a farm in the east of 'Turkey-much more than the limit set by Turkish law for someone his age. With his father unable to find employment, however, the burden of supporting the family fell upon Ismail. He earned about TRY 800 (USD 225) per month for his toil, which was little more than half of the statutory minimum wage in the country. ${ }^{2}$

1 P Kingsley, 'Syrians in Turkey: The human smuggler and the young refugee', New York Times, 24 March 2017, retrieved 14 September 2018, https:// www.nytimes.com/2017/03/24/world/europe/turkey-human-trafficking-refugeecrisis.html.

2 Republic of Turkey, Ministry of Labour and Social Security - Directorate General of Labour, National Programme on the Elimination of Child Labour, Ministry of Labour and Social Security - Directorate General of Labour, Ankara, 2017, p. 29; Republic of Turkey, Ministry of Labour and Social Security, Net Minimum Wages by Years, 2018, retrieved 14 September 2018, http://www.csgb.gov.tr/en/Contents/ Istatistikler/AsgariUcret. For indicators of trafficking for labour exploitation, see United Nations Office on Drugs and Crime, Human Trafficking Indicators, UNODC, Vienna, 2009, http://www.unodc.org/pdf/HT_indicators_E_LOWRES.pdf.

This is an open-access article distributed under the terms of the Creative Commons Attribution License (CC-BY). Under the CC-BY license, the public is free to share, adapt, and make commercial use of the work. Users must always give proper attribution to the authors and the Anti-Trafficking Review. 
Ismail also received permission for his family to set up a tent on the land of his employer as they struggled to find proper housing. Turkish law restricts refugees to residing in the province where they are registered, but the family had moved in search of work.

Refugees turning to smugglers; a refugee turned smuggler; a child who is an irregular migrant worker, but also a refugee and possibly even a trafficked person-categories as defined in international law blur before the complexities of contemporary migration. Yet, categorisations, and how these are applied, are of vital importance to people on the move as they may result in vastly different responses ranging from arrest and deportation to protection and other support. This Special Issue of the Anti-Trafficking Review deals with migratory categories, their use among authorities and humanitarian actors, and - most importantly_ the impact they have on migrants themselves. ${ }^{3}$

\section{Rising Numbers, Flawed Classifications}

Migration has been described as 'a mega-trend of our century'. ${ }^{4}$ Latest UN estimates indicate that the number of international migrants has grown by nearly 50 per cent since the start of the millennium, more than twice as fast as the world population, reaching a total of some 258 million in $2017 . .^{5}$ The

3 For other recent contributions to this debate, see for example: H Crawley and D Skleparis, 'Refugees, Migrants, Neither, Both: Categorical fetishism and the politics of bounding in Europe's "migration crisis", Journal of Ethnic and Migration Studies, vol. 44. no. 1, 2018, pp. 48-64; T Faist, 'The Moral Polity of Forced Migration', Ethnic and Racial Studies, vol. 41, no. 3, 2018, pp. 412-423.

4 Quote from 'William Lacy Swing, Director General, International Organization for Migration at the September Summit and Signing of the IOM-UN Agreement, International Organization of Migration, 19 September 2016, p. 1, retrieved 13 September 2018, https://www.iom.int/sites/default/files/about-iom/IOM-UNAgreement-Sept19-2016.pdf. Ant nio Guterres, then United Nations High Commissioner for Refugees, had already described migration as a 'mega-trend' in 2009; United Nations, 'Five "Mega-Trends" [...] Make Contemporary Displacement Increasingly Complex, Third Committee Told', Meetings coverage and press releases, United Nations (blog), 4 November 2009, retrieved 13 September 2018, https:// www.un.org/press/en/2009/gashc3964.doc.htm.

5 United Nations, Department of Economic and Social Affairs, Population Division, Trends in International Migrant Stock: The 2017 revision, UN DESA, New York, December 2017, retrieved 13 September 2018, https://www.un.org/en/ development/desa/population/migration/data/estimates 2/data/ UN_MigrantStockTotal_2017.xlsx; Department of Economic and Social Affairs, Population Division, World Population Prospects: The 2017 revision, vol. 1, Comprehensive tables, ST/ESA/SER.A/399.United Nations, New York, 2017, pp. xix, 2, https:// population.un.org/wpp/Publications/Files/WPP2017_Volume-I_ComprehensiveTables.pdf. 
closely linked phenomenon of internal migration, which is not included in this figure, is even more significant. ${ }^{6}$ In recent years, the persecution of the Rohingya in Myanmar, civil wars in Syria and South Sudan, the economic crisis of Venezuela, among others, have caused surges in cross-border migratory flows, and pushed migration to the top of political agendas in various parts of the world. Further, rising awareness of climate change has also drawn attention to the nexus between the environment and migration. ${ }^{7}$ Indeed, the ten largest displacement events of 2016 were climate-related, eight of which occurred in Asia. ${ }^{8}$

The increasing scale and complexities of human mobility have exposed the shortcomings in the current international legal framework on migration. Relevant norms are fragmented and incomplete, with the very term 'migrant' remaining undefined. In the absence of comprehensive, integrated legislation, applicable standards provide for partial and overlapping categorisations of people on the move, often designed to afford protection to specific sub-groups. Sources relate to asylum, crime, human rights, humanitarianism, labour, or the sea, and many go back to the decades between 1950 and 1980a period of significant global standard-setting in the wake of the Second World War. ${ }^{9}$

In response, the international community has been negotiating a strengthened cooperation framework to deal with human mobility for the past two years. In 2016, the UN General Assembly adopted the New York Declaration for Refugees

${ }^{6}$ R Skeldon, International Migration, Internal Migration, Mobility and Urbanization: Towards more integrated approaches, United Nations, New York, 7-8 September 2017, retrieved 14 September 2018, http://www.un.org/en/development/desa/population/ events/pdf/expert/27/papers/II/paper-Skeldon-final.pdf.

7 L Veronis, B Boyd, R Obokato and B Main, 'Environmental Change and International Migration: A review', in R A McLeman and F Gemenne (eds.), Routledge Handbook of Environmental Displacement and Migration, Routledge, Abingdon, Oxfordshire, 2018, pp. 42-70; V Mence and A Parrinder, 'Environmentally Related International Migration: Policy challenges', in M McAuliffe and K Koser (eds.), A Long Way to Go: Irregular migration patterns, processes, drivers and decision-making, ANU Press, Acton, Australia, 2017, pp. 317-342. First discussions of the migration-environment nexus date to the 1980 s.

8 S Opitz Stapletong et al., Climate change, migration and displacement: The need for a riskinformed and coherent approach, ODI, London and UNDP, New York, November 2017, retrieved 20 September 2018, https://www.odi.org/sites/odi.org.uk/files/ resource-documents/11874.pdf, p. 10.

9 See also Global Compact for Safe, Orderly and Regular Migration (Final Draft), retrieved 3 September, https://refugeesmigrants.un.org/sites/default/files/ 180711_final_draft_0.pdf, para. 2. 
and Migrants, in which member states committed to developing two Global Compacts, one for each group (Annexes I and II of the Declaration). ${ }^{10}$

The Global Compact on Refugees (GCR) seeks to strengthen refugees' self-reliance, broaden access to third-country solutions and generate conditions in countries of origin conducive to return in safety and dignity, whilst also ensuring that the burden of receiving and assisting refugees be shared more equitably among states. ${ }^{11}$ The final draft is expected to be adopted by the UN General Assembly in November 2018. The Global Compact for Migration ${ }^{12}$ (GCM) is designed to cover 'all dimensions of international migration in a holistic and comprehensive manner', ${ }^{13}$ whilst maintaining that 'migrants and refugees are distinct groups governed by separate legal frameworks' (para. 4, emphasis added). The GCM aims to mitigate factors in home countries that compel people to move, reduce the risks and vulnerabilities faced by migrants and support conditions that allow them to contribute to sustainable development. ${ }^{14}$ The GCM will be formally adopted at a dedicated intergovernmental conference in December 2018 .

The distinction made in the Compacts between migrants and refugees, stated in general terms, echoes a political discourse that in many countries is more specifically focused on controlling irregular migration — cross-border movement of people not authorised, and at times criminalised, by receiving states. The dominant narrative on irregular migration often posits a binary classification that is expressed in a variety of paired terms, contrasting victims with criminals,

10 United Nations, General Assembly, Making Migration Work for All: Report of the Secretary-General, United Nations, New York, 12 December 2017, para. 3, retrieved 13 September 2018, https://refugeesmigrants.un.org/sites/default/files/ sg_report_en.pdf.

11 UNHCR, The Global Compact on Refugees: UNHCR quick guide, retrieved 10 September 2018, http://www.unhcr.org/5b6d574a7.

12 Whilst the complete name is Global Compact for Safe, Orderly, and Regular Migration, the framework is more commonly referred to as the Global Compact for Migration.

13 IOM, 'Our Work: Global Compact for Migration', retrieved 7 September 2018, https://www.iom.int/global-compact-migration.

14 Global Compact for Migration, retrieved 5 September 2018, https:// refugeesmigrants.un.org/migration-compact. 
or forced with voluntary or economic migration. ${ }^{15}$ Migrants are thus divided into those deserving particular protections and assistance, and others who are undeserving $^{16}$ or even threatening, hence justifying defensive measures by states. In fact, the GCM has been criticised for placing too strong a focus on curbing cross-border movement and adopting a "root cause" approach' that casts 'migration as a problem to be solved rather than a phenomenon natural to humanity'. ${ }^{17}$ Yet, reductionist classifications are incapable of doing justice to current migration flows and enter all too easily into a feedback loop of mutual reinforcement with negative attitudes towards migrants. The latter, in recent years, have manifested themselves in countries across the world in a variety of ways, including open xenophobia at societal and policy levels. ${ }^{18}$

15 See: S Plambech, "Between "Victims" and "Criminals": Rescue, deportation, and everyday violence among Nigerian migrants', Social Politics, vol. 21, no. 3, 2014, pp. 382-402, esp. pp. 384-385. On media coverage of migration more generally, see: $\mathrm{M}$ MacAuliffe, W Weeks and K Koser, 'Media and Migration: Comparative analysis of print and online media reporting on migrants and migration in selected countries', in M McAuliffe and K Koser (eds.), A Long Way to Go: Irregular migration patterns, processes, drivers and decision-making, ANU Press, Acton, Australia, 2017, pp. 277315. In a baseline study of 13 countries, MacAuliffe, Weeks and Koser find that reporting is 'dynamic and quite sophisticated' and most often uses a humanitarian rather than an economic, sociocultural or security frame. The authors warn against sweeping statements lamenting one-sided coverage. The study is based on 2014 data. It remains an open question to what extent the surge of migrants arriving in Europe in 2015-2016 led to a change in media coverage in the region; see: W Allen, S Blinder and R McNeil, 'Media Reporting of Migrants and Migration' in World Migration Report 2018, International Organization of Migration, Geneva, 2018, pp. 191-207, esp. pp. 194-195. The authors maintain that reporting is 'largely negative' (p. 205).

16 Crawley and Skleparis, pp. 49, 60. It is worth noting, though, that the GCM recognises the importance of the protection and promotion of migrants' human rights and fundamental freedoms in various sections.

17 Mixed Migration Platform, MMP Note on the Zero Draft of the 'Global Compact for Safe, Orderly and Regular Migration', MMP, February 2018, p. 2, retrieved 13 September 2018, http://www.mixedmigration.org/wp-content/uploads/2018/07/48_mmpnote-on-gcm-zero-draft.pdf.

18 See, for example: T Scribner, 'You Are Not Welcome Here Anymore: Restoring support for refugee resettlement in the age of Trump', Journal on Migration and Human Security, vol. 5, no. 2, 2017, pp. 263-284; B A Vollmer, 'The Continuing Shame of Europe: Discourses on migration policy in Germany and the UK', Migration Studies, vol. 5, no. 1, 2017, pp. 49-64; S Gordon, 'Xenophobia across the Class Divide: South African attitudes towards foreigners 2003-2012', Journal of Contemporary African Studies, vol. 33, no. 4, 2015, pp. 494-509. 
The increasingly complex and individualised patterns of migration not only defy any classificatory logic - any attempt to neatly separate migrants into mutually exclusive groups; the fluid nature of migratory experiences-and hence of the legal status applicable to people on the move-is also incompatible with static categorisations. The empirical complexities of migration expose the overlaps and interstices of the categories defined in international law, as the following examples related to human trafficking, migrant smuggling and asylum illustrate.

The concepts of consent and exploitation in the definition of human trafficking, as laid down in the UN Trafficking Protocol, ${ }^{19}$ are key to differentiating between human trafficking and migrant smuggling. The former may appear theoretically intuitive but proves elusive in practice. Indeed, the Protocol offers little guidance on how to define consent and, in fact, complicates matters further by noting that consent is nullified when brought about by 'abuse of power or of a position of vulnerability', two similarly obscure terms. ${ }^{20}$ Moreover, conditions can change, and migrants who initially consented to a smuggling arrangement may subsequently find themselves exposed to varying degrees of coercion, abuse and exploitation-whether in transit or at destination, and be it at the hands of their smugglers or others. ${ }^{21}$ Further, the concept of exploitation - ultimately at the heart of all human trafficking-is not adequately defined either, as the Protocol only references certain extreme forms and no other source in international law provides much additional

19 UN General Assembly, Protocol to Prevent, Suppress and Punish Trafficking in Persons, Especially Women and Children, Supplementing the United Nations Convention against Transnational Organized Crime, 15 November 2000, (Trafficking Protocol), Art. 3 (a).

20 Some efforts have been made to further delineate consent in the context of human trafficking. For example, see: UNODC, Issue Paper: The Role of 'Consent' in the Trafficking in Persons Protocol, Vienna, 2014, retrieved 16 September 2018, http://www.unodc.org/documents/human-trafficking/2014/UNODC_ 2014_Issue_Paper_Consent.pdf.

21 N Perkowski and V Squire, 'The Anti-Policy of European Anti-Smuggling as a Site of Contestation in the Mediterranean Migration "Crisis", Journal of Ethnic and Migration Studies, 2018. On ransom, see: Y Goor, 'Ransom Kidnapping and Human Trafficking: The case of the Sinai torture camps', Berkeley Journal of International Law, vol. 36, no. 1, 2018, pp. 140, 143-150, 155-164. On the Mediterranean, see: P Monzini, N Abdel Aziz, and F Pastore, The Changing Dynamics of Cross-Border Human Smuggling and Trafficking in the Mediterranean, Istituto Affari Internazionali (IAI), Roma, 2015, pp. 42-46, retrieved 10 September 2018, http://www.iai.it/sites/default/files/ newmed_monzini.pdf. 
clarity. ${ }^{22}$ Such ambiguities render the distinction between human trafficking and migrant smuggling subject to a measure of arbitrariness and, as authorities determine the categories and treatment to be imposed upon migrants, allow for political agendas to shape outcomes. Increasingly restrictive migration policies and border control regimes, as put in place by many countries in recent years, suggest that current agendas are likely to have detrimental implications for the individuals concerned.

Asylum may also be linked with human trafficking and migrant smuggling. The United Nations High Commissioner for Refugees (UNHCR), in its Guidelines on International Protection, highlights that the exploitative experiences associated with human trafficking 'constitute serious violations of human rights [and] will generally amount to persecution. ${ }^{23}$ At the same time, the particular conditions faced by asylum-seekers and refugees often create vulnerabilities conducive to abuse and exploitation, including at times human trafficking. For example, the International Organization for Migration (IOM) identified 78 Rohingya refugees at Cox's Bazar, Bangladesh, as trafficked between October 2017 and July 2018, but expects the actual numbers to be much higher. It has also warned that thousands are vulnerable to such experiences, citing a lack of proper livelihood opportunities as a particular risk factor. ${ }^{24}$ Experiences of human trafficking may thus contribute to legitimate asylum claims, and vice versa. Moreover, asylum, as per its definition in international law, can only be sought outside a person's country of nationality. Given ever more rigid border control regimes in many countries, this means that asylum-seekers are frequently left with few choices but to revert to irregular migration channels, often facilitated by migrant smugglers, to access their right to protection under international law — a dilemma that the GCR has left largely unaddressed.

22 As with consent, some attempts have also been made to provide additional clarity around exploitation in the context of human trafficking. See for example: UNODC, Issue Paper: The Concept of 'Exploitation' in the Trafficking in Persons Protocol, Vienna, 2015, retrieved 16 September 2018, https://www.unodc.org/documents/ congress/background-information/Human_Trafficking/UNODC_2015_Issue_ Paper_Exploitation.pdf.

23 UNHCR, Guidelines on International Protection: The application of Article 1A(2) of the 1951 Convention and/or 1967 Protocol relating to the Status of Refugees to victims of trafficking and persons at risk of being trafficked, Geneva, 2006, retrieved 7 September 2018, http://www.unhcr.org/publications/legal/443b626b2/guidelinesinternational-protection-7-application-article-1a2-1951-convention.html.

24 F MacGregor, 'Thousands at Risk of Trafficking amid Rohingya Refugee Crisis', IOM press release, 31 July 2018, retrieved 8 September 2018, https:/ /www.iom.int/ news/thousands-risk-trafficking-amid-rohingya-refugee-crisis-iom. 
Since the early 2000s, humanitarian actors have advanced the concept of 'mixed migration' as a framework to capture the increasing complexities of migratory patterns, although a consensus on its definition has yet to emerge. ${ }^{25}$ According to Sharpe, conceptualisations of 'mixed migration' can be divided into two main approaches: one focuses on the heterogeneity of migratory flows in terms of the different profiles and needs among people on the move, whereas the other goes further and also defines 'mixed migration' with respect to the diversity of people's motivations for moving. Sharpe rejects the latter understanding, highlighting that it may exacerbate xenophobic views. Moreover, she argues that excluding motivation is consistent with the key principles of pertaining international law, which apply largely regardless of people's reasons for migration. ${ }^{26}$ Sharpe suggests that the concept of 'mixed migration' will have a greater theoretical and policy impact if its definition is centred on the heterogeneity of migratory flows alone. In emphasising protection needs rather than motives for movement, Sharpe's discussion calls for more integrated approaches to providing assistance to migrants that are tailored to their individual circumstances, in line with various contributions to this Special Issue of the Anti-Trafficking Review.

\section{Irregular Migrants, Refugees or Trafficked Persons?-This special issue}

Against this backdrop, the United Nations Action for Cooperation against Trafficking in Persons (UN-ACT) and Mahidol University in Bangkok coorganised the International Seminar on Mixed Migration in Southeast and East Asia on 21-22 June 2017. The event sought to help strengthen research and teaching related to different manifestations of migration and migratory outcomes as few universities in the region ${ }^{27}$ cover these phenomena in depth, which undermines the education of scholars and practitioners with pertinent expertise.

25 M Sharpe, 'Mixed Up: International law and the meaning(s) of "mixed migration', Refugee Survey Quarterly, vol. 37, no. 1, March 2018, pp. 116-138.

26 Sharpe's analysis considers humanitarian law, human rights law, refugee law, transnational criminal law, and the law of the sea in this context.

27 Mahidol University is one of only a few exceptions and maintains a research institute specialised in the field—-the Mahidol Migration Center. 
This Special Issue of the Anti-Trafficking Review builds on the conversation that began in Bangkok, providing it with a global platform. Contributors scrutinise the use and effects of migratory categories in light of the increasingly complex patterns of human mobility. The articles give voices to migrants in diverse contexts to explore how labels impact their lives. The settings examined comprise Italy, Indonesia and Malaysia, the Hong Kong Special Administrative Region of China, Peru, Mexico, and the United States.

Giorgia Serughetti opens the Special Issue with a case study of Nigerian women asylum-seekers in Italy, many of whom are identified as potential victims of human trafficking. The paper highlights the flaws of separating migrants into distinct categories to determine their treatment. Drawing on feminist political philosophy and philosophy of law, Serughetti uses the concepts of 'agency' and 'vulnerability' to discuss the role of stereotyping in labelling practices. Vulnerability, she points out, is key to the gendered and racialised construction of the 'deserving victim' and is often conceived of as characterised by impotence and passivity. The article rejects this construction and argues instead that vulnerability is both an intrinsic human condition and an individual experience conditioned by a person's position in the socio-economic order. Recognising the universal and systemic nature of vulnerability, Serughetti concludes, will help shift the focus of attention from people's motives for moving to their protection needs.

The following four papers examine different labels applied to migrants and how these impact their treatment by various actors. Benny Juliawan analyses current migratory patterns connecting Indonesia and Malaysia against the historical background of human mobility between the two countries. The article examines how government efforts to control and shape this movement clash with traditional flows, leaving many migrants in conditions of irregularity. Juliawan follows a group of Indonesian migrant workers in Malaysia as they are arrested and deported to their home country. Drawing upon their stories, the article demonstrates how the Malaysian state sees irregular migrants as criminals while Indonesian authorities treat returnees as victims deserving protection. Juliawan argues that these shifting categorisations reflect political imperatives in the two countries rather than migrants' experiences and narratives. He concludes that such state-centric responses fail to address the socio-economic realities underpinning migration between Indonesia and Malaysia, and will hence do little to change long-established patterns of human mobility. 
Jade Anderson and Annie Li discuss the potential overlaps between asylum and human trafficking based on the experiences of migrant domestic workers in Hong Kong, China. Derived from case files and follow-up interviews of NGO clients, they show how a clear-cut separation between the two legal frameworks as widely practised by government and civil society actors in the city creates a protection gap, with possibly severe repercussions for migrants. Anderson and Li emphasise that recognising the intersections between both phenomena, and developing more integrated approaches in response, is fundamental to ensuring that individuals in precarious conditions are granted the full range of rights and assistance they are entitled to. As the article shows, such efforts are particularly relevant in Hong Kong given extremely limited protections afforded under either framework.

For their part, Cécile Blouin and Emily Button scrutinise the construction and application of migratory categories in Peru against the background of changing patterns of human mobility, especially the recent influx of Venezuelans. Based on legal analysis and interviews with key migration actors in the country, the article illustrates the negative repercussions of a fragmented approach to migration on the human rights of migrants themselves. Blouin and Button, therefore, argue for a reversion to the fundamental human rights of people on the move. Similar to Anderson and Li, they suggest that state and civil society actors approach categorisations and protection frameworks in a more holistic, integrated manner. Blouin and Button conclude that, at an operational level, such a holistic approach requires overcoming institutional boundaries and strengthening inter-sectorial cooperation on human mobility among all relevant stakeholders.

Next, Katherine Soltis and Rebecca Walters examine the repeated failure of US authorities to identify and protect survivors of human trafficking who enlisted the services of migrant smugglers to enter the US. Drawing on legal analysis and case files of Central American refugees, they argue that increasing restrictions for, and criminalisation of, some forms of migration into the US contribute to victims of human trafficking being misidentified as 'illegal' or 'criminal aliens', with their legitimate claims for protection dismissed. Soltis and Walters note that this conflation is in part due to misunderstandings of relevant legal frameworks as well as flawed assumptions about people's lack of agency in cases of human trafficking. At the same time, they highlight that the problem also results from the dual mandates of law enforcement agencies tasked with both protecting trafficked persons and removing irregular migrants.

In the final thematic article, Gabriella Sanchez also focuses on the impact of intensified border controls, drawing attention to children engaged in migrant 
smuggling from Mexico to the US. She points out that this phenomenon is increasingly depicted by anti-trafficking and child rights advocates as a form of child trafficking committed by organised crime syndicates, with the young people, their families and communities often portrayed as naïve and vulnerable or dysfunctional and dangerous. Sanchez rejects this narrative as it considers neither the perspectives of children themselves nor the socio-economic and political environments contributing to their involvement in smuggling. The young people interviewed by her do not describe themselves as victims and make informed decisions to help alleviate the hardship faced by their families. The article highlights that the children's choices and actions are embedded in a context of historically evolved, local smuggling practices. Sanchez concludes that narratives portraying young people exclusively as victims of criminals risk reinforcing security-oriented responses such as migration control, which in turn increase children's socio-economic vulnerabilities.

For the debate section, we invited contributors to defend or reject the proposition 'It is important and necessary to make clear distinctions between (irregular) migrants, refugees and trafficked persons'. Katharine Weatherhead surprised us by proposing a critique of the way the statement is framed. She scrutinises the bracketing of 'irregular', arguing that it draws attention to the term and adds ambiguity to its meaning. Weatherhead notes two possible interpretations - one that recognises two closely related albeit separate groups, migrants and irregular migrants, and another in which the brackets dictate a reading of the term 'migrants' as 'irregular migrants', thereby risking to perpetuate negative associations in public discourse with people on the move.

The next two authors-Marika McAdam and Pia Oberoi-stop short of rejecting the proposition, even though they share concerns regarding the use of categorisations. McAdam argues that labels must be applied responsibly to ensure that people who are placed into one category do not lose out on entitlements they may have under another. She warns against a destructive turf war informed by ill-advised political agendas that risk undermining the protection of people caught in-between. In conclusion, McAdam emphasises the significance of our inherent human rights and urges that, irrespective of the labels applied to people, we must all remain indistinguishable in this regard.

Pia Oberoi argues along similar lines, but embeds her response in the context of the Global Compacts on Refugees and for Migration. She warns that the assumptions underpinning the division into two discrete and independent agreements risk distorting our handling of today's complex patterns of migration and protection needs. Oberoi introduces the emerging concept of 
'migrants in vulnerable situations', which refers to people on the move who are not in a position to effectively enjoy their human rights. In dealing with 'migrants in vulnerable situations', duty bearers are therefore under an obligation of heightened care. We must ensure, Oberoi concludes, that beyond the application of migratory categories every person on the move is granted the protection to which they are entitled based on their individual circumstances.

Finally, unlike McAdam and Oberoi, Sarah Elliot endorses the debate proposition. She acknowledges that there are support gaps for migrants, especially for those with irregular status. However, Elliot argues that it is still important to maintain distinctions between different categories of people on the move to safeguard the particular protections and freedoms that the international community decided to grant certain groups, such as refugees and victims of trafficking. The real challenge, according to Elliot, is to uphold such differences without a trade-off of rights to the disadvantage of migrants, who themselves are entitled to protections under international human rights law as well as other legislation that may apply to them as workers, children, stateless persons and beyond. She, therefore, reaches a similar overall conclusion as McAdam and Oberoi.

\section{Human Rights Up Front}

A consistent message across many of the contributions in this Special Issue is the call for a re-focus on existent rights, especially those to which all of us are entitled by virtue of our dignity as human beings. It may be hoped that, given their universal and inalienable nature, human rights are less exposed to political agendas and manipulation than other rights. ${ }^{28}$ Further, in emphasising commonality rather than difference between people, they are potentially a powerful tool in efforts to overcome xenophobia and to secure better protection for those in need.

28 Somewhat more sceptical: Faist, pp. 414-416, 421, who sees 'a tension between the political-cultural rights in national states and human rights in the rule of law' (p. 414). Moreover, according to Faist, human rights are only one possible rationale for the protection of forced migrants. In Turkey, Faist points out, other grounds are given for justifying the opening of the country to three million Syrian refugees. 
In 2013, then UN Secretary-General Ban Ki-moon launched the Human Rights Up Front Initiative (HRUF) after an internal review panel diagnosed a 'systematic failure' of the UN to respond to serious violations of human rights and humanitarian law during the end phase of the Sri Lankan civil war. ${ }^{29}$ The HRUF seeks to effect various changes in the UN including increased accountability and a cultural transformation leading staff to recognise human rights protection as a core responsibility.

Whilst the HRUF initiative is an important development, it also documents how human rights had fallen behind in a complex web of competing developmental priorities, even within a system developed to help protect and promote them. Safeguarding the human rights of migrants around the world requires a much broader, concerted effort underpinned by a renewed humanitarianism that is cultivated in civil society and extends into politics.

Building on these foundations, additional rights for several categories of people have been legislated at both national and international levels. As the analyses in this Special Issue demonstrate, it is imperative that each of these be promoted and protected without detriment to the application of other standards, thereby allowing migrants to gain access to the full range of safeguards they are entitled to under various protection frameworks. After all, an irregular migrant who was smuggled may also be a refugee and a trafficked person. This complexity in contemporary migratory flows requires investment in adequate, integrated screening mechanisms involving actors with competencies and mandates across all forms of mixed migration. It also makes it essential that protection needs be determined and met at an individual level, and be monitored over time as status-related vulnerabilities may contribute to experiences qualifying for additional protections.

Policy responses to people on the move must rise to the challenges posed by today's patterns of mixed migration, resisting temptations of reductionist or static categorisations. As the contributions to this Special Issue show, rightsespecially human rights_-must be put up front in this endeavour.

29 E Strauss, 'The UN Secretary-General's Human Rights Up Front Initiative and the Prevention of Genocide: Impact, potential, limitations', Genocide Studies and Prevention: An International Journal, vol. 11, no. 3, 2018, pp. 48-59. 
Claus K. Meyer is a lecturer at the Institute of Human Rights and Peace Studies at Mahidol University in Thailand. Meyer earned his Ph.D. from the European University Institute (Florence, Italy) with a comparative thesis on plantation slavery in South Carolina and manorialism in Brandenburg (Prussia). His interest now focuses on the empirical comparison of 'modern-day slavery' with historical slaveries. Email: claus.mey@mahidol.ac.th.

Sebastian Boll is the Regional Research Specialist at the United Nations Action for Cooperation against Trafficking in Persons (UN-ACT), a project of the United Nations Development Programme (UNDP) in the Greater Mekong Sub-region, where he oversees the research and learning portfolio. Mr. Boll has been based in different parts of Southeast Asia for the past 10 years, working on migration and exploitation. He holds degrees related to politics and international relations from the School of European Studies (The Hague, The Netherlands) and Aalborg University (Denmark). Email: Sebastian.boll@undp.org. 
Thematic Articles: Irregular Migrants, Refugees or Trafficked Persons? 


\title{
Smuggled or Trafficked? Refugee or job seeker? Deconstructing rigid classifications by rethinking women's vulnerability
}

\author{
Giorgia Serughetti
}

\section{Abstract}

In the context of recent large-scale migratory flows from North Africa to the European Union, significant convergence and overlap has been observed between human trafficking and migrant smuggling, and between 'economic' and 'forced' migration. This paper draws on the case of Nigerian women asylum seekers, most of whom are identified as potential victims of human trafficking, to illustrate the problems that arise when migrants are separated into discrete categories - trafficked/smuggled, voluntary/forcedto establish their treatment. These problems derive from the application of rigid bureaucratic labels to increasingly fluid migratory identities, and from gendered and neo-colonial stereotypes that inform views of agency and vulnerability. The paper discusses vulnerability as a core concept in the construction of the 'deserving victim' in order to critique stereotypical representations of 'vulnerable subjects' in light of feminist political philosophy and philosophy of law. In doing so, it highlights the role of receiving states in producing migrant women's vulnerability, and argues that state institutions have a duty to both guarantee protection and acknowledge the subjects' agency.

Keywords: human trafficking, agency, gender stereotypes, vulnerability, labelling, Nigeria, Italy, feminist philosophy

Please cite this article as: G Serughetti, 'Smuggled or Trafficked? Refugee or job seeker? Deconstructing rigid classifications by rethinking women's vulnerability', Anti-Trafficking Review, issue 11, 2018, pp. 16-35, www.antitraffickingreview.org

This is an open-access article distributed under the terms of the Creative Commons Attribution License (CC-BY). Under the CC-BY license, the public is free to share, adapt, and make commercial use of the work. Users must always give proper attribution to the authors and the Anti-Trafficking Review. 


\section{Introduction}

In the context of rising mixed migration flows towards Europe and shrinking opportunities for legal entry, migrants, including asylum seekers, from the Global South have increasingly resorted to the use of smugglers to facilitate their journeys. ${ }^{1}$ This compounds their vulnerability, not only to potentially cruel and inhuman treatment whilst travelling, but also to human trafficking.

Passing through the central Mediterranean route on their way to the European Union (EU), growing numbers of Nigerian women and girls have been landing on the coast of Sicily since 2013. Public authorities and humanitarian agencies have described this migration flow as part of an alarming increase in trafficking for sexual exploitation. ${ }^{2}$ Over these years, Nigerian women have also come to be more strongly represented within the population of asylum seekers in Italy. ${ }^{3}$

J Bhabha and M Zard, 'Smuggled or Trafficked?', Forced Migration Review, no. 25, 2006, pp. 6-8; J O'Connell Davidson, 'Troubling Freedom: Migration, debt, and modern slavery', Migration Studies, vol. 1, no. 2, 2013, pp. 176-195; L Shelley, Human Smuggling and Trafficking into Europe: A comparative perspective, Migration Policy Institute, Washington, DC, 2014.

2 See: International Organization for Migration, Human Trafficking through the Central Mediterranean Route: Data, stories and information collected by the International Organization for Migration, IOM, Rome, 2017; Group of Experts on Action against Trafficking in Human Beings, Report on Italy under Rule 7 of the Rules of Procedure for evaluating implementation of the Council of Europe Convention on Action against Trafficking in Human Beings, Council of Europe, Strasbourg, 2017; Italian Ministry of Interior and United Nations High Commissioner for Refugees (UNHCR), L'identificazione delle Vittime di Tratta tra $i$ Richiedenti Protezione Internazionale e Procedure di Referral, Rome, 2017. According to the IOM and UNHCR, 1,454 Nigerian women arrived in Italy in 2014, 5,633 in 2015, and 11,009 in 2016 (out of a total of 37,551 arrivals from Nigeria in 2016). Finally, in 2017, in the context of a general drop in arrivals by sea following the stipulation of a border control agreement between Italy and Libya, there were 5,425 sea arrivals of Nigerian women, accounting for 30 per cent of all arrivals from Nigeria. The International Organization for Migration believes that 80 per cent of these women are victims of human trafficking (see: IOM, Human trafficking).

3 According to Eurostat, asylum applications submitted by Nigerian women have increased year-on-year, both in absolute numbers and as a percentage of the total number of asylum seekers from Nigeria: 1,780 (out of 10,135) in 2014; 4,085 (out of 18,145 ) in 2015; 7,665 (out of 27,105) in 2016, 8,505 (out of 25,500) in 2017, see: Eurostat, Statistics on Asylum and Managed Migration, available at: http:// ec.europa.eu/eurostat/web/asylum-and-managed-migration/data/database. 
Overall, Nigeria was the main country of origin for irregular sea migration to Italy in 2016 and 2017, ${ }^{4}$ and currently accounts for the highest numbers of both victims of trafficking ${ }^{5}$ and asylum seekers in Italy. ${ }^{6}$ Nigerian migrants therefore offer a suitable case study to explore the interconnectedness of trafficking and smuggling along the migration route from North Africa to Southern Europe, and the convergence of voluntary and involuntary, economic and forced migration. Their case also serves to illustrate the ways in which European migration governance differentiates between 'victims' and 'criminals', ${ }^{7}$ and 'true' and 'bogus' asylum seekers. ${ }^{8}$

Distinguishing between human trafficking and migrant smuggling, forced and voluntary migration, is a key organising principle underpinning Italian and European political discourse and practice. The construction and application of distinct identities, such as irregular migrant, refugee, and victim of trafficking, is used to separate between those deemed as deserving protection and others to be deported. It is through this 'obsession with classification' that a differential recognition of rights is achieved. ${ }^{9}$ However, legal, political, and academic attempts to rigidly distinguish these subsets of migrants clash with increasingly overlapping migratory experiences that generate fluid and complex identities.

Migration studies have suggested the need to rethink the categories of forced and voluntary migration beyond the discursive constraints of bureaucratic distinctions, ${ }^{10}$ and to examine the impact of labels, especially on asylum seekers

4 UNHCR data service, available at: https://data2.unhcr.org/.

5 Department of Equal Opportunities and Rights, Vittime di Tratta, piu' di Mille Protetti Ogni Anno, available at: http://www.pariopportunita.gov.it/faqs/milleprotetti-ogni-anno/.

6 Eurostat.

7 S Plambech, "Between "Victims" and "Criminals": Rescue, deportation, and everyday violence among Nigerian migrants', Social Politics, vol. 21, no. 3, 2014, pp. 382-402.

8 J Freedman, Gendering the International Asylum and Refugee Debate, Palgrave Macmillan, New York, 2015.

9 C Marchetti and B Pinelli, 'Introduzione' in Confini d'Europa. Modelli di controllo e inclusioni informali, Cortina, Milano, 2017, p. XIX.

10 See: E Fussell, 'Space, Time, and Volition: Dimensions of migration theory' in M R Rosenblum and D J Tichenor (eds.), The Oxford Handbook of the Politics of International Migration, Oxford University Press, New York, 2012, pp. 25-52; S Castles, H De Haas, and M J Miller, The Age of Migration, Palgrave Macmillan, Oxford, 2014; M B Erdal and C Oeppen, 'Forced to Leave? The discursive and analytical significance of describing migration as forced and voluntary', Journal of Ethnic and Migration Studies, vol. 44, issue 6, 2018, pp. 981-998. 
and refugees. ${ }^{11}$ More recently, scholars have also approached this issue from a gendered perspective, showing that the application of rigid dichotomies fuels the dominant gendered and racialised discourse that serves as a tool for the moral and political governance of migration. ${ }^{12}$

In this paper, I first draw on the existing literature to illustrate the case of women who migrate irregularly from Nigeria to Italy. While tracing the different stages involved in the identification and reception of migrants, I discuss the specific problems that arise when categories defined by international, regional and national law are employed as mutually exclusive to separate them. I describe this separation as relying on labelling practices enacted by state and humanitarian actors, producing stereotypes of 'true' or 'bogus' asylum seekers, genuinely vulnerable persons and real victims. Second, I link the unsuitability of the bureaucratic categories to the underspecified and vague definition of the concept of vulnerability as codified in Italian and European legislation, and adopted in policies on migration, human trafficking and asylum. Finally, I argue that feminist philosophy can help highlight the role of migrantreceiving states in producing migrant women's vulnerability and the duty of state institutions to both guarantee protection and acknowledge the subjects' agency.

While other scholars have focused on the voluntary/forced binary with a view to interpreting these categories more clearly, ${ }^{13}$ in concentrating on the notion of vulnerability I do not set out to recommend more effective procedures for

11 See: R Zetter, 'Labelling Refugees: Forming and transforming a bureaucratic identity', Journal of Refugee Studies, vol. 4, no. 1, 1991, pp. 39-62; R Zetter, 'More Labels, Fewer Refugees: Remaking the refugee label in an era of globalization', Journal of Refugee Studies, vol. 20, no. 2, 2007, pp. 172-192.

12 See, among others: J Bhabha and M Zard; S Plambech; J Freedman, Gendering the International Asylum and Refugee Debate; J O'Connell Davidson; P Testaì, 'Debt as a Route to Modern Slavery in the Discourse on "Sex Trafficking": Myth or reality?', Human Security Journal, vol. 6, 2008, pp. 68-76; C Giordano, 'Practices of Translation and the Making of Migrant Subjectivities in Contemporary Italy', American Ethnologist, vol. 35, no. 4, 2008, pp. 588-606; R Andrijasevic, Migration, Agency and Citizenship in Sex Trafficking, Palgrave Macmillan, London, 2010; N Mai, 'Between Embodied Cosmopolitism and Sexual Humanitarianism: The fractal mobilities and subjectivities of migrants working in the sex industry' in V Baby-Collins and L Anteby (eds.), Borders, Mobilities and Migrations: Perspectives from the Mediterranean in the 21st century, Peter Lang, Brussels, 2014, pp. 175-192; N Mai, “"Too Much Suffering”: Understanding the interplay between migration, bounded exploitation and trafficking through Nigerian sex workers' experiences', Sociological Research Online, vol. 21, no. 4, 2016.

13 V Ottonelli and T Torresi, 'When is Migration Voluntary?', International Migration Review, vol. 47, no. 4, 2013, pp. 783-813; M B Erdal and C Oeppen. 
dividing migrants into different groups. Rather, my aim is to question the current regime of migration and border control, and to advocate for political responses that are sensitive to the protection needs of individuals.

\section{The Voluntary/Involuntary Dichotomy under Scrutiny}

The Protocol to Prevent, Suppress, and Punish Trafficking in Persons, Especially Women and Children (UN Trafficking Protocol), adopted in 2000 in tandem with the Protocol against the Smuggling of Migrants by Land, Sea and Air, defines human trafficking as an act-recruitment, transportation, transfer, harbouring or receipt of persons - carried out by means of threat, deception or coercion, among others, for the purpose of exploitation. While migrant smuggling is framed through voluntariness on the part of those who are smuggled, human trafficking implies a form of involuntariness, based on the use of means that vitiate the victim's consent to the subsequent exploitation. Additionally, this distinction centres on the relation of the trafficker/smuggler to subsequent exploitative conditions, with human trafficking requiring the continued exercise of control over a person, while the role of the smuggler is primarily to facilitate border crossing. ${ }^{14}$ The voluntary/involuntary binary is thus key in the framing of migrant smuggling and human trafficking, and is reflected in the more extensive obligations that states are deemed to have in relation to victims of trafficking than to smuggled persons. ${ }^{15}$ As stated by Bhabha and Zard, 'There is thus much to be gained from being classified as trafficked, and much to lose from being considered smuggled. ${ }^{16}$

However, the case of Nigerian women and girls arriving in Italy by sea illustrates that the conditions and practices involved in smuggling and trafficking can overlap and be difficult to disentangle. In recent years, it has been shown that multiple unorganised local agents, more often than international trafficking networks, set up transport and border-crossing arrangements for Nigerians migrating to Europe via Libya. ${ }^{17}$ These local agents are clearly engaged in the

14 B Anderson and J O'Connell Davidson, Is Trafficking in Human Beings Demand Driven? A multi-country pilot study, IOM Migration Research Series, no. 15, Geneva, 2003.

15 J O’Connell Davidson, p. 178.

16 J Bhabha and M Zard, p. 7.

17 L Beretta et al., Inter/rote: Storie di Tratta e Percorsi di Resistenza, Sapere Solidale, Rome, 2016; A Malakooti, Assessing the Risks of Migration along the Central and Eastern Mediterranean Routes: Iraq and Nigeria as case study countries, IOM, 2016; N Abdel Aziz, P Monzini, and F Pastore, The Changing Dynamics of Cross-border Human Smuggling and Trafficking in the Mediterranean, Report, New-Med Research Network, 2015. 
transportation and transfer of migrants-actions connected with human trafficking; they may also resort to threats and coercion, which constitute the means in human trafficking. However, the agents are primarily interested in profit from facilitating border crossings and thus fall under the international definition of smugglers. ${ }^{18}$ Moreover, it is not always easy to ascertain whether they pursue or benefit from the 'purpose of exploitation' even where migrants end up in exploitative circumstances along their route or at their destination. ${ }^{19}$

Further, sociological and anthropological studies suggest that migrants' reasons for leaving their country of origin are far more complicated than the dominant narrative of women and girls who have been deceived or forced to move against their will. ${ }^{20}$ Although some young Nigerians who are leaving their country have been tricked with false employment prospects, over the past several years prospective migrants have displayed increasing levels of awareness of sex work being the economic activity that is most likely available to them in Italy and other European countries. ${ }^{21}$ And yet, their migration may still turn into an exploitative experience, for example, due to unexpectedly harsh conditions of work in the destination country or a higher than anticipated migratory debt. ${ }^{22}$

18 E M-O Baye and S Heumann, 'Migration, Sex Work and Exploitative Labor Conditions: Experiences of Nigerian women in the sex industry in Turin, Italy, and counter-trafficking measures', Gender, Technology and Development, vol. 18, no. 1, 2014, pp. 77-105.

$19 \mathrm{~J}$ O'Connell Davidson.

20 L Agustín, Sex at the Margins: Migration, labour markets and the rescue industry, Zed Books, London, 2007.

21 M-L Skilbrei and M Tveit, 'Defining Trafficking through Empirical Work: Blurred boundaries and their consequences', Gender, Technology and Development, vol. 12, no. 1, 2008, pp. 9-30; S Vanderhurst, 'Governing with God: Religion, resistance, and the state in Nigeria's counter-trafficking programs', PoLAR: The Political and Legal Anthropology Review, vol. 40, no. 2, 2017, pp. 194-209; N Mai, 'Between Embodied Cosmopolitism and Sexual Humanitarianism'; N Mai, 'Too Much Suffering'.

22 C Giordano; E M-O Baye and S Heumann. On the monetary and moral bondage to which Nigerian women are subjected, and a critique of humanitarian and institutional narratives on this topic, see also: P Testai; I Peano, 'Bondage and Help: Genealogies and hopes in trafficking from Nigeria to Italy' in J Quirk and D Wigneswaran (eds.), Slavery, Migration and Contemporary Bondage in Africa, Africa World Press, Trenton, NJ, 2013. 
The above complexities make it challenging to distinguish between trafficking and smuggling. Although a smuggling agreement is seen as consensual, it too can lead to indebtedness and debt-induced exploitation, i.e. experiences similar to those encountered by victims of trafficking. ${ }^{23}$ The neat line of demarcation assumed by the two Protocols, between voluntary and consensual, and involuntary and non-consensual processes of migration, thus, is deeply problematic. ${ }^{24}$

It is equally difficult to use the voluntary/involuntary dichotomy to distinguish between economic and forced migration. ${ }^{25}$ Whereas refugees are assumed to have moved non-voluntarily to escape war or civil upheaval, political unrest, terrorism, or large-scale human rights violations in oppressive state regimes, economic migrants are usually represented as leaving their country voluntarily. This contrast may seem plausible as long as 'certain implications of staying (for example, being forced to change religion or being made a political prisoner) are recognised as an affront to human dignity and as unacceptable alternatives to fleeing, whereas other implications (for example, extreme poverty) are not seen in the same way'. ${ }^{26}$ However, while those who were 'forced to leave' may well have weighed up their decision against available alternatives and thus exercised a form of volition, job seekers may feel compelled to escape conditions of social and economic deprivation. Thus, to describe either decision to migrate as entirely voluntary or entirely forced is simplistic. ${ }^{27}$

Nevertheless, when migrants reach the coast of southern Italy, most are referred to so-called 'hotspots' and subjected to an initial screening designed to separate irregular 'economic' migrants from those who are entitled to apply for asylum. ${ }^{28}$ Their next destination will depend on the answers they give to the questions posed by Italian and EU authorities at the hotspots, especially those pertaining

23 J Bhabha and M Zard; J O'Connell Davidson.

24 B Anderson and J O'Connell Davidson; J Bhabha and M Zard; P Testai; J O'Connell Davidson; M B Erdal and C Oeppen.

25 V Ottonelli and T Torresi; M B Erdal and C Oeppen.

${ }^{26}$ M B Erdal and C Oeppen, p. 7.

27 Ibid., p. 2.

28 European Council for Refugees and Exiles, The Implementation of the Hotspots in Italy and Greece. A study, Dutch Council for Refugees, Amsterdam, 2016; Amnesty International, Hotspot Italy. How EU's flagship approach leads to violations of refugee and migrant rights, London, 2016; Council of Europe, Report to the Italian Government on the visit to Italy carried out by the European Committee for the Prevention of Torture and Inbuman or Degrading Treatment or Punishment (CPT) from 7 to 13 June 2017, Strasbourg, 2018. 
to the reasons for their journey. Based on their responses, they will be classified as asylum seekers, unaccompanied foreign minors, victims of trafficking, people with vulnerabilities or irregular migrants, the last of which results in a repatriation order. In recent years, there have been cases of large groups of Nigerian women, classified as job-seeking migrants, who were sent from landing sites to detention centres for deportation. ${ }^{29}$ This is despite a growing number of them being registered as asylum seekers. ${ }^{30}$

Further, only few Nigerians are referred to anti-trafficking programmes, although many are identified as potential victims of human trafficking by the International Organization for Migration (IOM). ${ }^{31}$ At the initial identification stage, it is difficult to discern victims of trafficking from a broader pool of migrants under the UN Trafficking Protocol. Recognition of trafficking is not only hindered by the complexities of mixed migration patterns and the actors involved, but also by the frequent discrepancy between the legal implications of migratory experiences and the perceptions of the migrants themselves. Many new arrivals who have been subject to human trafficking do not see themselves as victims of trafficking and are reluctant to identify with this status. ${ }^{32}$ In fact, the difficulties associated with unequivocally identifying Nigerian women as victims of trafficking persist even when they apply for asylum and are accepted into the reception and protection system, as discussed in the next section.

29 L Beretta et al., Commissione Straordinaria per i Diritti Umani, Rapporto sui Centri di Permanenza per il Rimpatrio, Italian Senate of the Republic, Rome, 2017.

30 Eurostat.

31 IOM, 'Human trafficking'. In 2016, out of a total of 6,599 Nigerian women and girls identified by the IOM as victims of human trafficking, 290 were reported to authorities or provided with assistance, while 135 were referred to the anti-trafficking network.

32 P Degani, 'Richiedenti Asilo e Vittime di Tratta nel Quadro dei Flussi Migratori misti tra Differenziazione dei Sistemi di Protezione e Necessita di Coordinamento dei Meccanismi di Referral', Pace diritti umani, no. 2, 2011, pp. 79-116; Y K Doherty and A Harris, 'The Social Construction of Trafficked Persons: An analysis of the UN Protocol and the TVPA definitions', Journal of Progressive Human Services, vol. 26, no. 1, 2015, pp. 22-45. 


\section{The Dual Protection Path and its Failures}

According to the United Nations High Commissioner for Refugees (UNHCR), inherent in the trafficking experience are such forms of severe exploitation as abduction, incarceration, rape, sexual enslavement, enforced prostitution, forced labour, removal of organs, physical beatings, starvation, the deprivation of medical treatment. Such acts constitute serious violations of human rights which will generally amount to persecution', and may thus justify the 'wellfounded fear of persecution' mentioned in the definition of 'refugee' under the 1951 Convention and the 1967 Protocol Relating to the Status of Refugees. ${ }^{33}$ Further, within the Common European Asylum System (CEAS), victims of trafficking are recognised as having special vulnerabilities requiring coordinated and effective responses, alongside single parents with children, pregnant or breastfeeding women, unaccompanied minors, and victims of torture, rape, or other serious forms of psychological, physical or sexual violence.

Moreover, Italian law ${ }^{34}$ states that applicants for international protection who are identified as victims of trafficking can benefit from a social assistance and integration programme, which includes measures enabling individuals to escape from the exploitation imposed upon them. According to the Italian Ministry of Interior and UNHCR, ${ }^{35}$ these provisions may also be applied to persons who have newly arrived on Italian territory, even when exploitation has not yet occurred.

Victims of trafficking who apply for asylum can therefore potentially benefit from a dual protection path, comprising recognition of their right to asylum on the one hand, and of their particular vulnerability due to their trafficking experience on the other. This dual recognition is subject to verification of at least one of two kinds of involuntariness on the part of the migrants: they must have either left their own country for reasons beyond their control, or been coerced or deceived into acting against their will.

33 UNHCR, Guidelines on International Protection: The application of Article 1A(2) of the 1951 Convention and/or 1967 Protocol relating to the Status of Refugees to victims of trafficking and persons at risk of being trafficked, UNHCR, 2006, available at http:// www.unhcr.org/publications/legal/443b626b2/guidelines-international-protection7-application-article-1a2-1951-convention.html.

34 Legislative Decree 18 August 2015, n. 142 - Implementation of Directive 2013/ 33 EU laying down rules on the reception of applicants for international protection, as well as Directive 2013/32/EU, laying down common procedures for the recognition and withdrawal of the status of international protection.

35 Ministry of the Interior and UNHCR, L'identificazione delle Vittime di Tratta tra $i$ Richiedenti Protezione Internazionale, Guidelines for the Territorial Commissions for the recognition of international protection, Rome, 2017. 
The notion of vulnerability in the international definition of human trafficking is ambiguous and generally interpreted in two main ways: first, as a condition produced by the experience of trafficking itself, from which special protection obligations derive for states; and second, as a characteristic of individuals and their environments that makes them more exposed than others to the risks of human trafficking. In its Legislative Guide for the Trafficking Protocol, the United Nations Office on Drugs and Crime articulates both interpretations. Firstly, the Legislative Guide states that '[p] ersons who have been trafficked are victims of the crime and are being exploited as a result of the trafficking and the intended or subsequent exploitation and through intimidation or retaliation on the part of the traffickers'. Secondly, the Legislative Guide highlights scenarios in which there is an 'abuse of a position of vulnerability', defined as 'any situation in which the person involved has no real and acceptable alternatives but to submit to the abuse involved'. However, defining what is 'acceptable' is challenging, and migrants, immigration authorities, nongovernmental and intergovernmental organisations may have very different perceptions in this respect.

When referring to victims of trafficking as 'vulnerable' asylum seekers, EU and Italian legislation understand 'vulnerability' as a condition acquired by individuals as a result of the trafficking experience and consider victims of trafficking as 'vulnerable' in this sense. However, to be recognised as vulnerable within the reception and protection system for asylum seekers, victims of trafficking must be successfully identified as such, and this requires them to produce a set of acts that are both declarative_ - affirming their victim statusand performative-acting in a manner that is consistent with the bureaucratic identity of a trafficking victim, the failure of which will lead to withdrawal of support measures. ${ }^{36}$

It has been noted, for example, that Nigerian women staying in shelters for asylum seekers risk losing part of their entitlements or being denied reception benefits entirely if they are found to be involved in sex work outside the facility. ${ }^{37}$ There have also been cases of Nigerian women whose asylum applications were rejected and for whom the courts ordered deportation to

36 For a critique of the procedures and practices implemented to identify 'victims of trafficking' and 'vulnerable asylum seekers' among Nigerian sex workers, see: C Giordano; S Plambech; E M-O Baye and S Heumann; and S Vanderhurst.

37 R Pascoal, 'The Vulnerability of Nigerian and Romanian Women in Sexual Exploitation. Motherhood as being a double vulnerability', PhD dissertation, Università di Palermo, 2018. 
prevent them from falling victim to sexual exploitation networks. ${ }^{38}$ Hence, the institutions of the Italian state may (and do) see women's engagement in sex work both as an expression of agency that is in contradiction with the condition of being a victim, and as a manifestation of vulnerability that obscures any residual capacity for agency in the context of a migratory plan.

Enrica Rigo analysed the asylum applications submitted by 56 Nigerian women and processed by Italian authorities between 2015 and 2016. Although the applicants' stories were similar, only seven were granted authorisation to stay in Italy for humanitarian reasons. The study suggests that the positive decisions were based on markers of the asylum seeker's vulnerability, notably her willingness to represent herself as a victim and to join an assistance and integration programme for victims of trafficking, along with her performance of the victim script. ${ }^{39}$

Difficulties in applying legal protections to refugees and victims of trafficking are therefore not so much due to the normative provisions themselves as to the labels used by the authorities in charge of managing migration and asylum. A critical discussion of such labels will advance our understanding of how stereotyping, especially in gender and racial contexts, acts to construct the victim in need of protection.

\section{Who is the Refugee? Who is the victim?}

Labelling has been defined as the dialectic of conformity to the bureaucratic requirements for the recognition of various forms of protection, in which asylum seekers become caught up when interacting with the institutions of the host country and humanitarian organisations. ${ }^{40}$ The asylum system, in Italy as in other countries, is characterised by the use of rigid bureaucratic classifications, which leads to forms of exclusion or inclusion. ${ }^{41}$

In analysing the 'refugee' label, Roger Zetter shows that, far from indicating a clear identity, the term captures an extremely complex set of values and judgements as it is contingent upon the intervention and interests of state

38 E Rigo, 'Donne Àttraverso il Mediterraneo. Una prospettiva di genere sulla protezione internazionale', Politeia, vol. XXXII, no. 124, 2016, pp. 82-94.

39 Ibid.

40 R Zetter, 'Labelling Refugees'; 'More Labels'.

${ }^{41}$ C Marchetti and B Pinelli. 
and non-state actors, and upon the actions and demands of the labelled subjects, who are requested to conform to and incorporate it. For Zetter, labelling is 'a process of stereotyping, which involves disaggregation, standardisation, and the formulation of clear cut categories'. ${ }^{42}$ Its corollary is 'control', because labels require compliance on the part of the individual, not uniqueness or singularity, and 'the need to conform to an institutionally imposed stereotype can both reinforce control and transform an identity'. ${ }^{43}$

When the subjects are women, the role of gender stereotyping in assigning the refugee label must also be taken into account. ${ }^{44}$ For example, stereotypes can be used to draw distinctions between 'true' and 'bogus' asylum seekers and refugees, or 'vulnerable' and 'threatening' subjects, ${ }^{45}$ depending on how closely they are seen to fit the ideals of women's innocence and helplessness on the one hand, and sexual and personal independence on the other. ${ }^{46}$ For example, the perceived vulnerability of women asylum seekers, often fuelled by culturalist stereotypes such as 'the weak Muslim woman, the defenceless Asian girl, the female victim of brutal tribal norms', ${ }^{47}$ may provide some with better chances to be granted asylum. However, the same preconceptions, by reinforcing the representation of women as 'passive' and 'apolitical' victims, can "create a continuing notion of "illegitimacy" of asylum claims based on the grounds of gender-related persecutions'. ${ }^{48}$ In addition, discourses that essentialise the impotence and passivity of the 'third world woman', ${ }^{49}$ constructing her migratory experience as one of extreme victimhood, make

42 R Zetter, 'Labelling Refugees', p. 44.

43 Ibid., p. 45.

44 M Calloni, S Marras and G Serughetti, Chiedo Asilo. Essere rifugiato in Italia, UBE, Milano, 2012; J Freedman, Gendering the International Asylum and Refugee Debate.

45 J Freedman, Gendering the International Asylum and Refugee Debate, p. 20.

46 J Doezema, 'Loose Women or Lost Women? The re-emergence of the myth of white slavery in contemporary discourse of trafficking in women', Gender Issues, vol. 18, no. 1, 2000, pp. 23-50; N Sharma, 'Anti-Trafficking Rhetoric and the Making of a Global Apartheid', NWS A Journal, vol. 17, no. 3, 2005.

47 J Bhabha, 'Demography and Rights: Women, children and access to asylum', International Journal of Refugee Law, vol. 16, no. 2, 2004, p. 231.

$48 \mathrm{~J}$ Freedman, 'Women's Right to Asylum: Protecting the rights of female asylum seekers in Europe?', Human Rights Review, no. 9, 2008, p. 431.

49 T C Mohanty, 'Under Western Eyes: Feminist scholarship and colonial discourses', Boundary 2, vol. 12, no. 3, 1984, pp. 333-358; R Kapur, 'The Tragedy of Victimization Rhetoric: Resurrecting the "native" subject in international/post-colonial feminist legal politics', Harvard Human Rights Journal, vol. 15, 2002, pp. 1-37. 
more nuanced and ambivalent expressions of suffering unrecognisable. ${ }^{50}$ Sex workers, in particular, may be seen as morally illegitimate for protection, if they do not claim being deceived, sold, and/or forced to sell sex. ${ }^{51}$

Labels such as 'vulnerable person' or 'victim of trafficking' also imply stereotyping and require a degree of conformity that does not always reflect the agency of the subjects involved. ${ }^{52}$ The dichotomy of coercion and consent informing the distinction between trafficking and smuggling translates into representations of victims of trafficking as passive, innocent and deserving of protection, unlike other migrants who are instead held accountable for a situation to which they consented. Often, there is also a gender and age dimension to this dichotomy, with women and children 'more likely to be considered as trafficked whilst men are more likely to be considered as smuggled (although this assumption is certainly open to question)'. ${ }^{53}$ For men, this implies a special invisibility within policies aimed at combating human trafficking and protecting its victims. ${ }^{54}$

As a result, asylum seekers at times need to make active use of labels as a survival strategy, exercising 'a very particular kind of agency in re-appropriating and mobilising these representations for their own benefit'. ${ }^{55}$ In other words, people may enact performative behaviours in an attempt to match one of the ideal types associated with those deserving protection, so as to maximise their chances of obtaining authorisation to stay. But this kind of agency can easily prompt a representation of women as "using their perceived "vulnerability" to "take advantage" of Western states'.56

When a wide range of socio-economic and cultural experiences of vulnerability and resilience are disregarded, when 'distinctions between self-identification and imposed labels ${ }^{57}$ are ignored, and when state benevolence is reserved for those who identify as victims and/or perform the realvictim script, access to protection may be denied to others who cannot, or do not want to offer a coherent story of victimisation, despite showing various signs of vulnerability.




Thus, the notion of vulnerability is key to the construction of the deserving victim, especially in relation to asylum seekers who are assumed to be victims of trafficking. The shortcomings in the practices and procedures assessing the reception and protection needs of Nigerian asylum seekers can be traced backat least partially - to stereotypes derived from an inadequate understanding of vulnerability. In particular, the interpretation of vulnerability as in opposition to and incompatible with the human capacity for agency and resilience, or as an essential characteristic of specific individuals and groups, has to be put under scrutiny. In the final section of the paper, I criticise this view, putting forward an alternative interpretation.

\section{Rethinking Vulnerability and Agency}

While, as noted earlier, vulnerability lacks an unequivocal definition in law, it is increasingly the focus of academic debate. As part of the so-called 'vulnerability turn', ${ }^{58}$ which has entailed increased use of the terms 'vulnerability' and 'vulnerable groups' in both EU policies and the case law of the European Court of Human Rights, a distinction has been drawn between the perspective of legal and political philosophy, on the one hand, and the sphere of political debate and applied legal scholarship, on the other. ${ }^{59}$ Whereas applied 'legal scholarship aims to normatively identify the class (or classes) of individuals who are particularly vulnerable and therefore in need of care and protection', philosophical reflection 'tends to deconstruct the very category of "vulnerable subjects", uncovering the specific mechanisms of domination and power concealed beneath it'. ${ }^{60} \mathrm{~A}$ crucial contribution to this deconstruction has been made by feminist philosophers.

58 D Morondo Taramundi, ‘ ¿Un Nuevo Paradigma para la Igualdad? La vulnerabilidad entre condición humana y situación de indefensión', Cuadernos Electrónicos de Filosofia del Derecho, no. 34, 2016, pp. 205-221.

59 O Giolo, 'Conclusions: Vulnerability and strength: A timeworn pairing in need of reconsideration', Gênero \&o Direito. Periódico do Núcleo de Estudos e Pesquisas sobre Gênero e Direito Centro de Ciéncias Jurídicas - Universidade Federal da Paraíba, vol. 5, no. 3, 2016, pp. 221-230.

(6) Ibid., p. 223. 
Various studies ${ }^{61}$ have approached this issue by critiquing the theoretical and political fiction of a sovereign subject (male, white, heterosexual and ablebodied) who stands in contrast with a dependent and vulnerable subject that is in need of care. ${ }^{62}$ Within the modern Western tradition, rational subjects have imagined themselves to be free and independent, denying their intrinsic vulnerability only to project it onto someone or something else, outside of and beneath the sphere of the human: 'women, children, the insane, the poor, prisoners, the colonized, slaves, homosexuals, the disabled, the elderly, etc'. ${ }^{63}$ In opposition to this view, philosophers like Adriana Cavarero ${ }^{64}$ and Judith Butler ${ }^{65}$ have reinterpreted vulnerability as an intrinsic quality of human beings, who due to their constitutive bodily fragility are radically exposed, from birth to death, to the possibility of injury (vulnus).

Recognising vulnerability as intrinsic to the human condition debunks any notion of a mutually exclusive opposition between vulnerability and agency. Martha Nussbaum, in Upheavals of Thought, argues that the status of victim, which reflects our human vulnerability to disgrace, and the status of agent, which is attributed with dignity, are presented in the form of a rigid binary; yet, it is crucial to recognise that 'agency and victimhood are not incompatible'. ${ }^{66}$

${ }^{61}$ See, in particular: A Cavarero, Horrorism: Naming contemporary violence, Columbia University Press, New York, 2008; A Cavarero, Inclinations: A critique of rectitude, Stanford University Press, Stanford, 2016; J Butler, Precarious Life: The powers of mourning and violence, Verso, New York, 2004; J Butler, Frames of War: When is life grievable?, Verso, New York, 2009; J Butler, Notes for a Performative Theory of Assembly, Harvard University Press, Cambridge, 2015; J Butler, 'Rethinking Vulnerability and Resistance' in J Butler, Z Gambetti and L Sabsay (eds.), Vulnerability in Resistance, Duke University Press, Durham and London, 2016, pp. 12-27; M Fineman, 'The Vulnerable Subject: Anchoring equality in the human condition', Yale Journal of Law \& Feminism, vol. 20, no. 1, 2008, pp. 1-23; M Fineman, The Vulnerable Subject and the Responsive State, Emory University School of Law, Public Law \& Legal Research Paper Series, 2010.

62 B Casalini, 'Politics, Justice and the Vulnerable Subject: The contribution of feminist thought', Gênero \& Direito. Periódico do Núcleo de Estudos e Pesquisas sobre Gênero e Direito Centro de Ciéncias Jurídicas - Universidade Federal da Paraíba, vol. 5, no. 3, 2016, pp. 15-29.

63 L Re, 'Introduction: The vulnerability challenge', Gênero \& Direito. Periódico do Núcleo de Estudos e Pesquisas sobre Gênero e Direito Centro de Ciéncias Jurídicas - Universidade Federal da Paraíba, vol. 5, no. 3, 2016, p. 3.

64 A Cavarero, Horrorism; Inclinations.

65 See, in particular: J Butler, Precarious Life and Frames of War.

${ }^{6} \mathrm{M}$ Nussbaum, Upheavals of Thought: The intelligence of emotions, Cambridge University Press, Cambridge, 2001, p. 406. 
Making a similar point, Judith Butler condemns the tendency to transform recognition of vulnerability into a form of paternalism that locks groups identified as 'vulnerable' into a political position of impotence and lack of agency; for the two constructs are not mutually exclusive, but rather interdependent. ${ }^{67}$

In Butler's theorising, this perspective on vulnerability has been further refined to include the distinction between an ontological dimension and a social, economic and political one: ${ }^{68}$ "As much as "vulnerability" can be affirmed as an existential condition, since we are all subject to accidents, illness, and attacks that can expunge our lives quite quickly, it is also a socially induced condition, which accounts for the disproportionate exposure to suffering, especially among those broadly called the precariat for whom shelter, food, and medical care is often quite drastically limited. ${ }^{69}$

In line with this reading of a differential experience of vulnerability is Martha Fineman's emphasis on the responsibility of the state in relation to the production of conditions of vulnerability, and on the need for resources to address and mitigate such conditions: 'The counterpoint to vulnerability is not invulnerability, for that is impossible to achieve, but rather the resilience that comes from having some means with which to address and confront misfortune. ${ }^{70}$ Like Butler, Fineman also draws attention to the dual nature of vulnerability as both a constant of the human condition and as an effect of social, economic and institutional relationships. ${ }^{71}$ This leads her to distinguish vulnerability as a universal feature from vulnerability as the particular experience of individuals who are positioned differently in social, economic and institutional relationships and whose position greatly influences the quality and quantity of resources they possess or can command. An intersectional approach is required, Fineman argues, to explore the 'systems of power and privilege that interact to produce webs of advantages and disadvantages'. ${ }^{72}$

67 J Butler, Notes for a Performative Theory of Assembly; 'Rethinking Vulnerability and Resistance'.

68 Ibid.

69 J Butler, 'Rethinking Vulnerability and Resistance', p. 25.

${ }^{70}$ M Fineman, The Vulnerable Subject and the Responsive State, pp. 31-32.

71 Ibid. pp. 28-30.

72 M Fineman, 'The Vulnerable Subject: Anchoring equality in the human condition', p. 16. 
Returning to the protection of Nigerian women asylum seekers in Italy who are identified as potential victims of trafficking, the above reflections on vulnerability allow us to advance a critique of how the notion is used within the Italian asylum system and its interaction with the anti-trafficking framework, and to propose an interpretation that is more sensitive to the complexity of people's experiences.

Raising awareness of vulnerability as a universal condition, one that all human beings share, will help us to go beyond dualistic approaches that position vulnerability and agency along the lines of gender, race, geographical origin, age, ability, etc. Further, concurrently exploring vulnerability as a peculiar experience of groups and individuals will provide us with insight into the factors exacerbating it. These not only include situations of armed conflict, political instability, humanitarian emergencies, and environmental crises, but also structural inequalities reflected in access to resources, discrimination, or domestic violence. Gender power structures, for instance, make migrant women vulnerable not only in their regions of origin, but also in the host country. ${ }^{73}$

Recognising vulnerability as both a constant in human beings and an effect of social, economic and institutional relationships brings to light the role played by a multiplicity of actors, going beyond those responsible for deviant activities such as smuggling and trafficking. Indeed, scrutiny of the processes of vulnerability production underpinned by the unequal distribution of privilege exposes vulnerability as a systemic feature of our social order, and points to the role played by states and supranational institutions. For example, national and European border control policies, by minimising opportunities for legal access, generate demand for the facilitation of irregular border crossings and make migration routes more dangerous. Ultimately, therefore, restrictive border control policies contribute to the increasingly violent actions of smugglers and to conducive conditions for human trafficking. ${ }^{74}$

73 J Freedman, Gendering the International Asylum and Refugee Debate; J Freedman, 'Engendering Security at the Borders of Europe: Women migrants and the Mediterranean "crisis", Journal of Refugee Studies, vol. 29, issue 4, 2016, pp. 568582; G Serughetti, 'Richiedenti Asilo e Vittime di Tratta. Le donne fra vulnerabilità e resilienza' in C Marchetti and B Pinelli, Confini d'Europa. Modelli di controllo e inclusioni informali, Cortina, Milano, 2017, pp. 63-93.

74 N Abdel Aziz, P Monzini, and F Pastore; L Achilli and G Sanchez, 'Introducing the Human Smugglers Roundtable', Open Democracy, 26 March 2016, retrieved 31 January 2018, https://www.opendemocracy.net/beyondslavery/hsr/luigi-achilli-gabriellasanchez/introducing-human-smugglers-roundtable. 
The responsibility of state institutions and other humanitarian actors for producing migrants' vulnerability is not limited to the systems put in place to manage arrivals, but extends to the overall governance of migration, including the policies and practices for the identification and reception of newcomers illustrated above, with their structural weaknesses, disciplinary aims, labelling practices, and outcomes of social abandonment. ${ }^{75}$

In addition, greater attention to the particular vulnerability to which some individuals may be exposed, as suggested by Judith Butler and Martha Fineman, will help us to transcend an approach based on the identification of a single cause of fragility for an entire group of individuals - such as sex, pregnancy, dependent children, age, disability, or an experience of torture, sexual violence, or human trafficking. This more differentiated framework will make us more sensitive to the intersection of different factors of disadvantage. As a result, it becomes possible to extend the notion of 'particular vulnerability' to include the situations of people who do not fall within the categories defined as vulnerable in legislative and bureaucratic guidelines, and who risk being represented as invulnerable.

Finally, the philosophical discussion illustrated above, by challenging the association of human vulnerability with characteristics of passivity and impotence, suggests that we view the capacity for resistance or resilience as a possible expression of a vulnerable condition rather than as its denial. This means deconstructing the rigid dichotomies that shape labels such as victim of trafficking or vulnerable person, which tend to link, on the one hand, deservingness of protection with the lack of individual agency, and on the other hand, the capacity for resistance and resilience with invulnerability. Individual and collective resistance to unjust and violent regimes can be understood as informed by vulnerability, where the latter is conceived as 'a constituent feature of a human animal both affected and acting', that can be marshalled and mobilised for the purpose of asserting one's existence or claiming one's own rights. ${ }^{76}$ Resilience, on the other hand, is nothing more than the human ability to cope with vulnerability as a universal condition. ${ }^{77}$ While this capacity does not imply the eradication of vulnerability, it requires resources with which individuals are unequally equipped. It is therefore the responsibility of societal

75 I Peano; E M-O Baye and S Heumann.

76 J Butler, 'Rethinking Vulnerability and Resistance', p. 26.

77 M Fineman, 'The Vulnerable Subject: Anchoring equality in the human condition'; The Vulnerable Subject and the Responsive State. 
institutions and organisations to provide the means necessary for resilience to be strengthened, in order to lessen, ameliorate and compensate the condition of vulnerability. ${ }^{78}$

\section{Conclusion}

This paper has drawn on the literature examining human trafficking and asylum from a gendered perspective to scrutinise labelling practices and procedures that are intended to separate migrants into discrete categories. It has illustrated how these attempts to separate fail to acknowledge the specific protection needs of individuals because they are insufficient to the task of capturing increasingly overlapping phenomena that are generating progressively complex migrant identities.

In particular, the case of Nigerian women migrating to Italy, many of whom are registered as job-seeking migrants, but concurrently identified by the IOM as potential victims of trafficking, clearly illustrates the fallacy of the voluntary/ involuntary dichotomy and reveals the preconceptions underlying the recognition of some migrants as deserving of protection and others as undeserving.

I have argued that at the core of the deserving victim label is an understanding of vulnerability as an invariable characteristic of individuals and their environments, which constrains or erases their ability to make meaningful choices and act as autonomous agents. This understanding has been challenged by feminist philosophers such as Cavarero, Nussbaum, Butler, and Fineman, who have questioned stereotypical representations of vulnerable subjects and vulnerable groups, suggesting that vulnerability is both a constant in human beings and a condition experienced differentially, based on people's position within a web of social, economic, and institutional relationships. Further, they claim that this condition cannot be separated from the human capability for agency, which is to be conceived, likewise, as both universal and particular.

Based on the work of these scholars, I have highlighted the role played by migrant-receiving states in producing migrant women's vulnerability. I have argued that it is the duty of state institutions to guarantee protection, both by alleviating vulnerability and supporting resilience, and recognising the ability

78 Ibid. 
of migrants to determine their own lives. State and humanitarian actors fail to fulfil their duty of protection not only when they base their legislation, policies, and practices on misconstrued concepts of vulnerability and employ rigid and stereotypical labels, but also when they fail to acknowledge agency and respect people's, and especially women's, choices.

Instead of objectifying asylum seekers and victims of trafficking, I have contended that we need to attend to the lived experiences of women who, because of the harmful actions of a multiplicity of institutional and noninstitutional actors, have been forced to undertake dangerous journeys and have often suffered various forms of violations of their rights. This means rejecting both the transformation of women into passive recipients of humanitarian action, and the criminalisation and expulsion of those with non-conforming identities.

More broadly, such a perspective requires us to recognise that being exposed to violence and risks of exploitation can determine a particular state of vulnerability in any subject that is beyond classifications based on the smuggling/trafficking, economic/forced, or voluntary/involuntary binaries. This conceptual evolution may prompt us to shift our focus from analysing migrants' reasons for departure towards assessing their protection needs upon arrival, demanding more responsibility of migrant-receiving states.

Giorgia Serughetti is a postdoctoral research fellow at the Department of Sociology of the University of Milano-Bicocca, Italy. She has conducted studies on migration, human trafficking, sex work and men who pay for sex. Her current research focuses on feminism, prostitution, and public policy. Email: giorgia.serughetti@unimib.it. 


\title{
Seeing Migration like a State: The case of irregular Indonesian migrant workers deported from Malaysia
}

\author{
Benny Hari Juliawan
}

\begin{abstract}
The corridor linking Indonesia with Malaysia is particularly rife with transborder mobility, including large-scale labour migration. While irregularity has long been a major feature of these flows, much of the movement now falls under the migration regimes adopted by Malaysia and Indonesia. Long-established casual migration flows collide with recently codified norms and, as a result, oscillate between regularity and irregularity. This paper explores the following questions: How does the regulatory state view and handle undocumented migrants? How does it interact with established social networks that have facilitated irregular labour migration? Particular attention is given to the distinction between the categories of deportable criminals and victims deserving protection, as ascribed by state actors to certain groups of migrants. Based on interviews with twelve deported Florenese migrant workers, the paper discusses how the Indonesian-Malaysian migration regime seeks to shape mobility. It argues that shifting categorisations reflect political imperatives more than the migrants' needs that prompt them to migrate in the first place.
\end{abstract}

Keywords: deportation, Indonesia, criminal/victim, Malaysia, irregular migration

Please cite this article as: B H Juliawan, 'Seeing Migration like a State: The case of irregular Indonesian migrant workers deported from Malaysia', AntiTrafficking Review, issue 11, 2018, pp. 36-51, www.antitraffickingreview.org

This is an open-access article distributed under the terms of the Creative Commons Attribution License (CC-BY). Under the CC-BY license, the public is free to share, adapt, and make commercial use of the work. Users must always give proper attribution to the authors and the Anti-Trafficking Review. 


\section{Introduction}

Irregularity has long been a major feature in Indonesia's labour migration. The corridor linking the country with Malaysia is particularly rife with this irregular transborder mobility. Since colonial times, migrants from the island of Flores have plied the route both to East and West Malaysia in search of better livelihoods and adventure. ${ }^{1}$ Much of this movement now falls under the migration regimes adopted by Malaysia and Indonesia. Consequently, longestablished casual migration flows now collide with recently codified norms. Migrants have developed a wide array of responses to this new challenge, ranging from outright resistance to reluctant compliance with legal requirements. As a result, migration flows oscillate between regularity and irregularity.

A crucial element in these dynamics is the desire of the state, both in Malaysia and Indonesia, to bring the cross-border movement of people under its control. The underlying logic is strongly informed by economic considerations, given the income and employment gaps between the two neighbouring countries. While Indonesia suffers from chronic unemployment and low wages, Malaysia's economy depends heavily on foreign workers, who make up around 15 to 25 per cent of the total labour force. ${ }^{2}$ Labour migration between the two countries offers real opportunities to address these issues, and the prospect of mutual benefits has encouraged the two governments to facilitate the movement of workers, notwithstanding occasional tensions illustrated by the deportation of around 400,000 Indonesian migrants from Malaysia in $2002 .^{3}$

1 I B Mantra, 'Indonesian Labour Mobility to Malaysia (A case study: East Flores, West Lombok, and the Island of Bawean)' in Sukamdi, A Haris and P Brownlee (eds.), Labour Migration in Indonesia: Policies and practice, Population Studies Centre UGM, Yogyakarta, 2000, pp. 143-184.

2 Given an unknown number of undocumented migrant workers, figures reported vary considerably. An old estimate from 2008 quotes a figure of 25 per cent. See: V Kanapathy, Controlling Irregular Migration: The Malaysian experience, ILO, Bangkok, 2008. More recent survey data for 2016 mention 15.6 per cent (Labour Force Survey), 17 per cent (National Employment Returns), and 24.4 per cent (independent estimate). See: L Hwok-Aun and K Y Leng, 'Counting Migrant Workers in Malaysia: A needlessly persisting conundrum', ISEAS Perspective, no. 25, 2018, pp. 7-8.

3 M Ford, 'After Nunukan: The regulation of Indonesian migration to Malaysia' in A Kaur and I Metcalfe (eds.) Mobility, Labour Migration and Border Controls in Asia, Palgrave Macmillan, New York, 2006, pp. 228-247. 
Modern statecraft determined to bring about social order is well captured in James Scott's Seeing Like A State (1998). ${ }^{4}$ Scott highlights how nation-states are premised on a vision of large-scale social engineering and seek to develop the requisite capacity and tools. In this context, society is often perceived as a chaotic entity separate from the state: '[It] became an object that the state might manage and transform with a view toward perfecting it. ${ }^{5}$ The improvement of all members of society is a central purpose of the modern state, in addition to the classic goals of taxation, conscription and prevention of rebellion. At the same time, similar to earlier efforts at theorising the modern state, ${ }^{6}$ Scott's work points out the flip side of state ambitions to order social life. Social engineering is necessarily schematic and limited; it objectifies society and conceptualises its features according to its own needs, such as the requirements of urban planning, industrial production, settlement or land ownership. This simplified picture or map feeds into plans for control and interventions, which are often at odds with a functioning social order. Little wonder, therefore, that such efforts often fall short of their objectives and, in some cases, yield disastrous results as the tragedies cited in Scott's book illustrate.

Labour migration policies are a case in point: they frame the movement of people in terms of national interests including economic growth and border control. ${ }^{7}$ However, such policies often ignore the social and political dimensions of labour migration, especially in a context where social networks significantly shape migration opportunities. This paper unpacks these complex dimensions as 'systematically interlinked technologies, institutions, and actors that facilitate and condition mobility'. ${ }^{8}$ Different factors are at play, colliding, collaborating and shaping mobility. An important element in the process are the shifts in the designation of migrants, who are in some context seen as criminals deserving punishment and in others as victims meriting help and

J C Scott, Seeing Like A State, Yale University Press, New Haven, 1998.

Ibid., p. 92.

Z Bauman, Modernity and the Holocaust, Polity Press, Cambridge, 1991.

M Ford, L Lyons and W van Schendel, 'Labour Migration and Human Trafficking: An introduction' in M Ford, L Lyons and W van Schendel (eds.), Labour Migration and Human Trafficking in Southeast Asia: Critical perspectives, Routledge, Abingdon, 2012, pp. 1-22.

8 J Lindquist and B Xiang, 'The Infrastructural Turn in Asian Migration' in G LiuFarrer and B S A Yeoh (eds.) Routledge Handbook of Asian Migrations, Routledge, London, 2018, p. 154. 
protection - a contradiction that has attracted interest in research within critical trafficking and deportation studies. ${ }^{?}$

Following the deportation from Malaysia of twelve migrant workers from Raburia village in Ende district, Flores, Indonesia, this paper discusses how the experience of deportation is shaped by shifting legal regimes in Malaysia and Indonesia, as well as by the migrants' multiple vulnerabilities. Arrested and punished as criminals in Malaysia, the twelve workers were deported back to Indonesia, where state authorities treated them as victims.

\section{Modern Statecraft in Controlling Migration}

For Malaysia and Indonesia, necessities dictate the management of migrant workers. Although labour importation had started in colonial times, Malaysia's reliance on migrant workers became more acute after the start of the exportindustrialisation drive in the early 1980s, which triggered massive urbanisation at the expense of the agricultural sector. In-migration at that stage was perceived only as a temporary solution to 'sustain labour market demand and to maintain Malaysia as a favourable site to foreign investors'. ${ }^{10}$

Over the years, it became clear that the demand for migrant workers was anything but temporary. Employment prospects in Malaysia motivated Indonesian workers to cross the border even without proper documents, their movement facilitated by a relaxed attitude to irregularity among many state officials on both sides of the border. To illustrate, the number of irregular migrant workers in Malaysia increased from an estimated 1.9 million in 2010 to 2.5 million in 2014. ${ }^{11}$ In addition, a tacit recognition of Malaysia's heavy reliance on foreign labour often revealed itself in policy reversals following

9 S Plambech, "Between "Victims" and "Criminals": Rescue, deportation and everyday violence among Nigerian migrants', Social Politics, vol. 21, no. 3, 2014, pp. 382-402; E Paasche, ML Skilbrei and S Plambech, 'Vulnerable Here or There? Examining the vulnerability of victims of human trafficking before and after return', Anti-Trafficking Review, issue 10, 2018, pp. 34-51.

10 E S Devadason and C W Meng, 'Policies and Laws Regulating Migrant Workers in Malaysia: A critical appraisal', Journal of Contemporary Asia, vol. 44, no. 1, 2014, p. 22.

11 C C Low and K S Mokhtar, 'Deportation Turn in Malaysia: Expansion, discourse and practice', Journal of Population and Social Studies, vol. 25, no. 2, 2017, p. 148. 
crackdowns on irregular migrants. ${ }^{12}$ Such reversals are actually indicators of different views among state institutions regarding migrant workers. The Malaysian Ministry of Human Resources and other related ministries recognise the importance of foreign labour to the economy. On the other hand, the Ministry of Home Affairs sees migrant workers as a security issue that has to be responded to with increased surveillance and reduction in numbers.

Irrespective of occasional reversals, Malaysian policies have shown an overall trend towards increased border control. Low and Mokhtar describe the country's current migration governance as a 'deportation regime' and divide its development into four periods: 1) pre-1992 (securitisation of operations); 2) 1992-2002 (militarisation of operations); 3) 2002-2010 (zero-tolerance policy); and 4) post-2010 (deportation turn). ${ }^{13}$ Each period is characterised by increasingly punitive policy measures. For example, in 1992 the government launched the two-pronged Operation Expunge (Ops Nyah) to counter irregular migration. While the police assumed responsibility for preventing new arrivals (Ops Nyah I), the military was deployed to arrest irregular migrants already in the country (Ops Nyah II). Caning was introduced in 1997 for 'double backers', or deportees who returned to Malaysia as irregular migrants, and expanded to first-time offenders in 2002. A biometric system was launched in 2005 to prevent re-entry. In the 2010 s, the government fundamentally reformed the 'deportation regime' by increasing the capacity of detention centres, by expediting trials and deportations and by collaborating with the governments of sending countries and with international agencies such as the UN High Commissioner for Refugees, the International Committee of the Red Cross and the International Organization for Migration. As of 2015, the Malaysian government ran fourteen permanent and three temporary detention facilities with a total capacity of 18,350 inmates. ${ }^{14}$

Across the border, the Indonesian government responded to the end of the oil bonanza in the early 1980s by initiating labour out-migration policies 'to mitigate the unemployment problem, to increase skills and working experience abroad and to improve the foreign exchange position'. ${ }^{15}$ Indonesia joined a growing group of developing countries with labour surpluses, which integrated

12 Kanapathy.

13 Low and Mokhtar, p. 148.

14 Ibid., p. 155.

15 G Cremer, 'Deployment of Indonesian Migrants in the Middle East: Present situation and prospects', Bulletin of Indonesian Economic Studies, vol. 24, no. 3, 1988, p. 78. 
overseas employment into their national development strategies. ${ }^{16}$ Formal protections only came much later with Law no. 39 of 2004 on the protection and placement of Indonesian overseas workers, and its subsequent replacement, Law no. 18 of 2017. Over time, migrant workers' contributions to the national economy increased steadily. By 2015, remittances had reached USD 10.5 billion and amounted to just over one per cent of the country's GDP. ${ }^{17}$ Government parlance accordingly glorifies migrant workers as 'pablawan devisa' or 'heroes of foreign exchange'.

Such narratives of success are often accompanied by reports about the hardship and abuses suffered by Indonesian workers abroad. Accounts from the early period of labour migration painted a gloomy picture: workers suffered from 'very long working hours, sometimes from dawn to after midnight, payments below the amount stated in the contract, delays in payment, berating and beating, or sexual abuse and rape'. ${ }^{18}$ A report on Indonesian plantation workers in Sabah, Malaysia, described their conditions as 'bonded labour... modern kind of slavery'. ${ }^{19}$

Public outcries and pressures from civil society groups bore fruit with the ratification of the UN Convention on the Protection of the Rights of All Migrant Workers and Members of Their Families in 2012. However, it took five years and various legal drafts before a new law implementing the Convention was passed (Law no. 18 of 2017). This protracted legislative process suggests that labour migration is still very much a contested space between business profitability and efficiency, on the one hand, and measures to provide protection to workers, on the other.

These shifts in government policies and narratives help condition the mobility of migrant workers. The regulatory dimension of the migration regime prescribes the appropriate treatment of migrants in various situations and informs the reactions of people around them, but, as I argue in this paper, it does not always produce the intended perceptions and experiences of migration on the part of the migrants themselves.

16 C B Chin, Walls of Silence and Late Twentieth Century Representations of the Foreign Female Domestic Worker: The case of Filipina and Indonesian female servants in Malaysia', International Migration Review, vol. 31, no. 2, 1997, pp. 353-385.

17 World Bank, Migration and Remittances Factbook. 2016, World Bank, Geneva, 2016, p. 21.

18 Cremer, pp. 81-82.

$19 \mathrm{~T} \mathrm{M} \mathrm{Li}$, 'To Make Live or Let Die? Rural dispossession and the protection of surplus populations', Antipode, vol. 41, 2009, p. 77. 


\section{Methods}

This paper is based on a research project to understand the phenomenon of repatriation, funded by the migration network of the Jesuit Conference of Asia Pacific (JCAP). Primary data were collected by interviewing twelve Florenese male construction workers, ranging from 16 to 56 years of age, who were deported from Malaysia having been caught without proper documents in September 2015. Employment on plantations and in the construction sector in Malaysia is taken up mostly by migrant workers, comprising around 70 per cent of the sectors' total workforce in 2014, according to the Malaysian Employers Federation. ${ }^{20}$ Men dominate the physically demanding work in these sectors, and Florenese men, in particular, are perceived as capable of such hard outdoor labour, thought to resemble work in their home villages.

The interviews took place in February 2016, while the workers were in a temporary shelter in Jakarta, and on two separate occasions in June and November 2016, when they were back home. In the shelter, group interviews were conducted because it was difficult to arrange separate conversations in a crowded space. Moreover, an exclusive interview would have made the respondent stand out and feel uncomfortable. In the village, two local contact persons helped establish rapport with the village chief, who himself had gone twice to Malaysia as a plantation worker. The chief knew the deportees and their stories and endorsed my fieldwork, which, given his authority, facilitated my interviews. In the safety of their home village, the respondents were more outspoken, although private interviews still made them uncomfortable because they were not familiar with the concept of interviewing. In the end, four of the twelve agreed to be interviewed individually while the others were interviewed as a group. All twelve agreed to the publication of their names. A longer stay with the respondents would probably have yielded richer insights, but the JCAP research grant was very limited and could not support more extensive fieldwork.

To corroborate the data, interviews were also conducted with ten other former male migrant workers in Malaysia from a neighbouring village. These men went to Malaysia in different periods but their experiences confirmed the stories of the migrants from Raburia: undocumented mobility, multiple entries to Malaysia, working in plantations and construction sites, arrest and deportation. The fieldwork also included interviews with five local activists and three officials from local authorities in Ende district, who were responsible for labour

20 Hwok-Aun and Leng, p. 7. 
migration affairs. Further, government records in Jakarta and in Ende supplement the interview data.

\section{Criminalising a Functioning Labour Migration}

The ordeal of the twelve returnees from Raburia in Ende began when the van they were travelling in was stopped by the police on a road in Kampung Gajah area in Perak, Malaysia, in the middle of the night sometime in September 2015. They were part of the 256 irregular migrants that were arrested daily that year, of whom one third were Indonesians. ${ }^{21} \mathrm{Up}$ to that point, the men had been working as a group for the same employer on a construction site. That evening they were being transported to a new site where they were to start their work the following morning. When the men could not produce documents, the police immediately detained them along with the Malaysian driver, who was released shortly afterwards.

Despite hailing from the same village and being arrested as a group, the men actually did not come to Malaysia at the same time. Xaverius (42 years old) and Bartolomeus (30 years old) were veteran migrants who had been in and out of Malaysia four times, each lasting from one to two years; Kasimirus (40 years old) had been to Malaysia three times; and the teenager Heribertus (17 years old) had previously been to Malaysia when he was only 12 years old. For the others, this was their first migration to Malaysia, and they had been in the country between one and six months prior to the arrest. All of them were never in possession of proper documents while in Malaysia.

The men had known each other, being neighbours and some even relatives in the same village. In fact, it is quite common for Indonesian migrants to bring friends and relatives to Malaysia to work in the same place, a practice that is encouraged and facilitated by employers. Xaverius brought his neighbour with him when going back to Malaysia for the second time, and Heribertus followed his uncle to work in a plantation back in 2011. The village network or indeed the network of people from the same district shapes the migration process in a way that has become convenient to both migrants and employers: the migrants need not spend time looking for jobs while the employers can access a pool of labourers from a distance. Furthermore, this informal channel reduces costs both for the employers, who circumvent the requirements for work permits,

${ }^{21}$ Low and Mokhtar, p. 157. 
and for the prospective workers, who bypass lengthy and bribery-ridden placement bureaucracies. ${ }^{22}$

The same network supports the return of the migrants. Extensive knowledge of the migration route and leverage with relevant officials on both sides of the border facilitate a smooth journey back home. Indeed, the border between the two countries is made porous partly by corrupt immigration officers, whose involvement is often ignored in law enforcement efforts targeting only migrants and their immediate handlers. ${ }^{23}$

The current circular labour migration inserts itself into a long-established pattern linking Flores and Malaysia. Seafaring communities had moved within the region long before the colonial era. The British added a new dimension to these migratory flows when they imported foreign workers from South China, the Philippines, India and Indonesia for the growing economy of colonial Malaya. Some of these workers settled and later became citizens of independent Malaysia. ${ }^{24}$ Once established, networks of migrants often acted as sponsors and helped to facilitate the arrival of more migrant workers when there was demand in subsequent periods. The influx of migrants from Flores, in particular, became greater after the introduction of large-scale agricultural estates and the rise of the timber industry in the 1950s. ${ }^{25}$ Combining traditional kinship networks and trans-border mobility, the Florenese over time established a vast network of labour migration with outposts in many places along the routes that connect Flores and Malaysia. In fact, given the extent of the network that now straddles the border between Indonesia and Malaysia in places like East and West Kalimantan and the Riau Islands, one scholar suggests that the Florenese constitute an embryonic transnational community. ${ }^{26}$

The arrest of the twelve migrant workers by the Malaysian authorities interrupted this otherwise functioning system of labour allocation. Driven by the vision of order, the authorities committed what Scott calls 'state

22 G Hugo, 'Best Practice in Temporary Labour Migration for Development: A perspective from Asia and the Pacific', International Migration, vol. 47, no. 5, 2009, p. 30.

23 A M Nah, 'Globalisation, Sovereignty and Immigration Control: The hierarchy of rights for migrant workers in Malaysia', Asian Journal of Social Science, vol. 40, no. 4, 2012, pp. 486-508.

24 Mantra, p. 144.

25 R Tirtosudarmo, On the Politics of Migration: Indonesia and beyond, LIPI Press, Jakarta, 2015, p. 217.

26 Ibid., p. xxxv. 
simplification' in treating the detained men mainly as individuals to be punished for a criminal activity. Just the same, some scholars suggest that the Malaysian policies on in-migration are deliberately designed to leave a grey area that can be exploited to fulfil the continuous demand for migrant workers. ${ }^{27}$ In any event, arrests by the authorities do not always spell the end of employment in Malaysia. The presence of millions of undocumented migrant workers would not be possible without some degree of complicity on the part of the authorities. Arrests sometimes simply serve as a way to solicit bribes. Xaverius and his friends noted that they actually tried to offer some money to the policemen that night. However, the checkpoint was being supervised by a high-ranking officer and so the policemen on duty did not accept the bribes offered.

The police took the group to a detention facility in Sri Iskandar. After three weeks, the men were transferred to a prison in Taiping, where they had to go on trial. They were found guilty of working irregularly and sentenced to six months' imprisonment, for which the authorities moved them to yet another prison in Tapah. Life in detention was hard, and the money the men had on them at the time of their arrest was taken away without explanation. When the men had served two-thirds of their term in Tapah prison, the Malaysian authorities deported the group to Indonesia.

\section{The Construction of Victimhood in Indonesia}

Once the men set foot on Indonesian soil, the social protection regime kicked in. Unlike in Malaysia, the migrants were not treated as criminals, although they had clearly broken the Indonesian laws on migrant worker placement and immigration. Instead, the Indonesian authorities treated the men as victims deserving assistance and protection. This response came automaticallyofficials made no attempt to check whether the men had suffered any injustice or exploitation. In particular, nothing was done to ascertain whether they had become victims of human trafficking. The authorities' approach was probably informed by a popular perception that the government is incapable of protecting its own citizens. ${ }^{28}$

\section{Devadason and Meng.}

28 Public outcries criticising perceived government inaction usually follow news of Indonesian migrant workers executed abroad for alleged crimes or when cases of abuse surface, such as the one about Erwiana who was physically tortured by her employer in Hong Kong in 2013. 
For a number of reasons, however, treatment as victims does not necessarily qualify returnees to seek redress in the Indonesian justice system. First, provisions for redress mainly concern administrative dispute resolutions and insurance schemes, which only apply to documented migrants. Second, the Indonesian judicial system (e.g. for cases of human trafficking) is notoriously treacherous. Individuals seeking justice face systemic barriers such as cost, time, the need for expertise as well as perceived bias and corruption. In addition, migrant workers often suffer from multiple vulnerabilities such as poverty, low levels of education and little formal work experience, rendering the barriers to justice even greater.

The provision of state protection comes together under the policy framework for 'Pekerja Migran Bermasalah' (PMB), or 'Migrant Workers with Problems'. ${ }^{29}$ The Decree of the Minister of Social Welfare no. 22/2013 defines these as: 'Indonesian overseas migrant workers who have no work permits, legal documents, and/or who work in violation of their work permits, [and have] encountered problems in terms of violence, exploitation, deportation, neglect, social disharmony, [or] inability for self-adjustment.' The decree also stipulates that the Ministry of Social Welfare is responsible for repatriating the returnees from the point of arrival in Indonesia to their home province where regional governments take over the process and provide them with transportation to their home districts and eventually on to their villages.

This shift in the categorisation of the men as they returned from Malaysia to Indonesia reflects the ongoing discussion about the linkage between 'deportable criminals and virtuous victims deserving of protection' ${ }^{30}$ Indeed, as has been highlighted in research on other populations, both criminalisation in Malaysia and victimhood in Indonesia do not reflect the main experiences of the deported individuals, as illustrated later.

From Port Klang in Malaysia, the group arrived in Tanjung Balai, North Sumatra, and was immediately taken to a rehabilitation centre for victims of domestic violence and exploitation, run by the Ministry of Social Welfare and known as Rumah Perlindungan dan Trauma Centre (RPTC), or House of Protection and Trauma Centre. The shelter authorities banned the men from

29 For extensive descriptions of Indonesia's legal frameworks of assistance for trafficking victims, migrant workers and vulnerable persons, see: R Surtees et al., Going Home. Challenges in the reintegration of trafficking victims in Indonesia, Nexus Institute, Washington DC, 2016.

30 See, for example, Plambech's work on Nigerian sex workers in Europe; Plambech, p. 384 . 
going out — a measure usually taken to prevent a return to Malaysia. Although the migrants from Flores found themselves confined to the facility, the regime of the shelter did not include any activities to help them pass their time. After ten long days, the men were taken by boat to Tanjung Priok port in Jakarta. Upon arrival, the authorities gave each of them IDR 250,000 (USD 17.5) as pocket money, and they were immediately taken to the RPTC in East Jakarta run by the Ministry of Social Welfare, a large facility handling an increasing number of PMBs. ${ }^{31}$

The mandate of RPTCs as outlined in the Decree of the Ministry of Social Welfare no. 102/2007 is quite comprehensive. The centres are to provide food, temporary accommodation, and clothing to their clients and to offer healthcare, including psycho-social rehabilitation and trauma healing. The shelters are also supposed to prepare the returnees for reintegration with their families and communities, in collaboration with regional governments. Moreover, the RPTCs play the role of crisis centres. Finally, they are tasked with gathering information from returnees and running public information campaigns on migration.

However, an internal review commissioned by the Ministry in 2015 criticised the centres for failing to meet their responsibilities. ${ }^{32}$ RPTCs operate on a very small budget and each institution only employs one or two civil servants, who work as the coordinator and secretary, assisted by volunteers. The review mentions, for example, how the RPTC in Bambu Apus Jakarta struggles with the financial burden of having to feed and repatriate an increasing number of deported migrants. High medication bills for serious cases of illness or injury stretch the meagre budget even further. The recently established national health insurance scheme is of little help as it requires identity documents that undocumented migrants are lacking.

The twelve men from Raburia luckily did not have serious physical or mental problems. It was mostly boredom that troubled them while in the shelter. They spent about a week in the facility until, on 13 February 2016, they were taken back to Tanjung Priok port from where they travelled by boat to Maumere in Flores. No staff from the RPTC or from any government agency

31 In 2013, this facility handled 763 returnee migrants; in 2014, the figure was 935; and by June 2015, the figure was already 769; Kementrian Sosial, Perlindungan Sosial Pekerja Migran Bermasalab melalui Rumah Perlindungan Trauma Center, Kementrian Sosial, Jakarta, 2015, p. 35.

32 Husmiati et al., Perlindungan Sosial Pekerja Migran Bermasalah melalui Rumah Perlindungan Trauma Center, P3KS Press, Jakarta, 2015. 
accompanied them on the trip. They were given tickets, a little more money and an official cover letter to be handed over to the Dinas Sosial, the Office of Social Welfare, in Maumere. The boat took four days to reach the men's destination. Once disembarked, the group was supposed to go to the Dinas, report their arrival and receive further assistance, but by the time the vessel reached the port it was late in the evening, and the office of the Dinas was closed. Although aware of the instructions from Jakarta, the men 'could not be bothered to wait until dawn to access the Dinas' as Xaverius, the de facto leader of the group, would later report. '[They] simply wanted to get home as soon as possible.' Their village could not be directly reached by cars. From Maumere, it would take them about four hours on the road to travel to a point from which relatives could take them home on motorbikes. The men decided to use what remained of the pocket money they had received for the trip and mobilised their kinship network to arrange their journey.

The repatriation procedure stipulates that, once returnees arrive in the provincial port, the local government agencies will take over from the ministry and accompany them to their home villages. In reality, no one in the Dinas in Maumere or Ende was aware of the Raburia returnees. 'I have double-checked. We do not know anything about the deported migrants from Raburia,' confided Romanus Tato, the head of the department of social security and assistance of the Dinas Sosial in Ende. Similarly, Yoseva Dewi, the head of the responsible department in the Dinas Tenaga Kerja, or Labour Agency, in Ende knew nothing of them.

This lack of coordination is often blamed on the decentralisation policy that started in 2001 as part of the political reform following the demise of the New Order regime. Decentralisation is supposed to encourage greater public participation in development by transferring some of the powers from Jakarta to the regions. It is meant as a means of improving public services, reducing inefficiency and corruption, and deepening democracy. ${ }^{33}$ Under this policy, local governments are authorised to reorganise departmental offices and reallocate the resources according to their priorities. Whatever its benefits in other areas, however, the decentralisation policy often complicates coordination between the various levels of government.

33 J Manor, The Political Economy of Democratic Decentralization, The World Bank, Washington DC, 1999; A Dasgupta and V A Beard, 'Community Driven Development, Collective Action and Elite Capture in Indonesia', Development \& Change, vol. 38, no. 2, 2007, pp. 229-249. 
The Ministry of Social Welfare and the related Dinas in the regions are part of a special task force, or satgas, that is responsible to facilitate the safe return of deported migrants in each region. Other members are delegated by the coordinating Ministry of People's Welfare, the Ministry of Home Affairs, the Ministry of Law and Human Rights, the Ministry of Labour and Transmigration, the Ministry of Health, the Ministry of Women's Empowerment and Child Protection and the National Agency for the Protection and Placement of Indonesian Migrant Workers (BNP2TKI). ${ }^{34}$ In reality, though, only officials from the local Dinas of Social Welfare, the local Dinas of Labour and Transmigration, and the local representatives of BNP2TKI are present in the field, albeit not always in a coordinated manner. On various occasions, officials from the agencies complained about the lack of collaboration and a culture of blaming other institutions in areas of shared responsibility. ${ }^{35}$

\section{Life after Deportation}

Back in the village, the men quickly resumed their routines in the field, but problems remained: all had taken out loans to finance their trip to Malaysia and were struggling to repay their debts - an issue also documented by another study on migrant workers in the area. ${ }^{36}$ According to the villagers interviewed, locals typically borrow money from loan sharks who charge a fixed annual interest rate of 100 per cent even if the debtor can repay the loan in a period shorter than a year.

Such was the case of Heribertus. For his first trip to Malaysia, his mother borrowed 3 million rupiah (USD 226). After four months, he had earned enough to repay the debt of 6 million rupiah, including interest. Similarly, Bartolomeus had borrowed 5.5 million rupiah so that his total debt, including interest, amounted to 11 million (USD 828). Before he got caught, he had

34 Under the Presidential Decree no. 106 of 2004, this task force is called the Coordination Team for the Repatriation of Indonesian Migrant Workers with Problems and Their Families or TK-PTKIB in its Indonesian acronym. This legislation has been replaced by the more generic Presidential Regulation no. 45 of 2013, which does not significantly change the substance of the old law.

35 Husmiati et al., p. 60.

36 G Hugo, 'International Labour Migration and Village Dynamics: A study of Flores, East Nusa Tenggara' in T R Leinbach (ed.), The Indonesian Rural Economy: Mobility, work and enterprise, Institute of Southeast Asian Studies, Singapore, 2004, pp. 120122. 
paid 6 million rupiah from his savings of 11 months and now still had to find another 5 million. A third member of the group, Yohanes, had taken out a loan of 2 million rupiah (USD 145) and had to repay 4 million. Having worked for just a month before deportation, though, he had no money left to settle his debt.

'It is hard here. We really struggle to make ends meet. Food is not a problem, but other expenses are difficult,' said Bartolomeus, referring in particular to his child's school fees. He added, 'I have a plan to go back to Malaysia.' Xaverius was not yet decided, but would not exclude the possibility of returning to Malaysia. 'For me it would not be so soon. I do not know for sure.' These anecdotal accounts help to shed light on the reason why people from this region have continued to embark on the risky migration to Malaysia. Indebtedness, lack of education and job opportunities continue to haunt them while irregular migration, facilitated in part by established social networks, offers a real opportunity. ${ }^{37}$ Treatment as victims by Indonesian authorities does nothing to improve the living conditions of deported returnees, nor does the criminalisation of irregular migrants in Malaysia provide an effective deterrent. In other words, while the criminal/victim categorisation helps to shape mobility, it does not significantly change the structure of migration opportunities.

Further, the twelve men at the focus of this study did not face blame and rejection by their families or community for their failed adventure. At the time of the interviews, 20 out of 179 families in the village had at least one of their members, mostly men, working in Malaysia. As their remittances are essential for the families, their absence is seen as normal and potential failure of a migration as an accepted risk. This assessment is consistent with Surtees's study on the reintegration of trafficked men from Java island, and in contrast with the negative reactions returning migrant women often have to face from their communities. ${ }^{38}$

37 E Spaan and T van Naersen, 'Migration Decision Making and Migration Industry in the Indonesia-Malaysia Corridor', Journal of Ethnic and Migration Studies, vol. 44, no. 4, 2018, pp. 680-695. See also: N van Hear, O Bakewell, and K Long, 'Drivers of Migration', Migrating out of Poverty Research Programme Consortium Working Paper 1, University of Sussex, Brighton, 2012, p. 15.

38 R Surtees, 'At Home: Family reintegration of trafficked Indonesian men', AntiTrafficking Review, issue 10, 2018, pp. 70-87. See also: E Prusinski, 'Wasted Talent', Inside Indonesia, 12 April 2014, retrieved 23 July 2018, http:// www.insideindonesia.org/wasted-talent. 


\section{Conclusion}

The labour migration route that connects Indonesia and Malaysia brings together two distinct logics of operation-one of the state and another of social networks - each having distinct actors, forces and strategies. The regulatory infrastructure of the state has tried to rein in the social and commercial infrastructures of the Florenese transnational community both at the sending and receiving ends, but it gives little consideration to the complexities that inform the reproduction of labour migration and the vulnerabilities experienced by rural populations from Indonesia's outer provinces. The study of deportation offers a glimpse into those complexities.

The Indonesian and Malaysian governments do not fully recognise the ways in which the social networks of Florenese migrants shape opportunities, sanction movements and give meaning to labour migration so that village families can reap its economic benefits. The increasingly punitive migration regime devised as a tool of statecraft by Malaysia designated the Raburia men as criminals, ignoring their need for earning a living and supporting their families. Indonesian authorities, by contrast, under pressure for being unable to create employment and provide protections, responded by treating the returnee migrants as victims. In other words, both governments insist on working within the legal frameworks that primarily serve their national interests, but ignore the living conditions and needs of the migrants and their families.

The deported migrants interviewed for this study fully understood the risks and consequences of migrating without documents, but did not consider themselves victims or criminals. The shifting identification of criminal/victim reflects political imperatives more than the experiences of the migrants, who do not take centre stage and for whom the policies offer little innovation. Thus, perceiving migration like a state will not change significantly the established mobility pattern of undocumented migrants.

Benny Hari Juliawan is a lecturer in the Graduate School of Religious and Cultural Studies at Sanata Dharma University in Yogyakarta, Indonesia. His main research interests cover trade union movements, labour migration and politics of marginalised groups. Email: benny.juliawan@usd.ac.id. 


\title{
Refugees or Victims of Human Trafficking? The case of migrant domestic workers in Hong Kong
}

\author{
Jade Anderson and Annie Li
}

\section{Abstract}

China is party to the 1951 Refugee Convention and the 2000 UN Trafficking Protocol, but has not extended coverage of either of the treaties to the Hong Kong Special Administrative Region of China (Hong Kong). Hong Kong does however offer non-refoulement protection on the basis of risks of torture or persecution. Further, Hong Kong legislation defines human trafficking, albeit only in terms of cross-border sex work. Victim identification also remains inadequate. The limited extant protection systems for refugees and victims of human trafficking operate separately and assume that such people are distinct with respect to their experiences and needs. These practices are often mirrored in the approaches of NGOs working in the city. Based on research undertaken by Justice Centre Hong Kong, this paper argues instead that boundaries between the two categories are blurry. The paper focuses on migrant domestic workers who may have claims to asylum and may be at the same time victims of human trafficking. It explores some of the implications for NGOs trying to secure better protections for such groups in Hong Kong. The paper concludes that siloing the refugee and the human trafficking frameworks creates a protection gap, particularly for people who enter Hong Kong as migrant domestic workers and cannot return home because they face a risk of persecution or torture.

Keywords: human trafficking, migration, refugee, migrant domestic worker, Hong Kong, non-refoulement, refugee status determination, Unified Screening Mechanism

Please cite this article as: J Anderson and A Li, 'Refugees or Victims of Human Trafficking? The case of migrant domestic workers in Hong Kong', Anti-Trafficking Review, issue 11, 2018, pp. 52-68, www.antitraffickingreview.org

This is an open-access article distributed under the terms of the Creative Commons Attribution License (CC-BY). Under the CC-BY license, the public is free to share, adapt, and make commercial use of the work. Users must always give proper attribution to the authors and the Anti-Trafficking Review. 


\section{Introduction}

Hong Kong is rarely considered in the context of contemporary concerns with refugee flows or human trafficking. Where protection systems for refugees and victims of human trafficking exist in Hong Kong, they operate separately and assume that these are distinct categories of people with different experiences and needs. Such distinctions are also reflected in the practices of many nongovernment organisations (NGOs), which assist refugees or victims of human trafficking (mainly among migrant domestic workers or sex workers) but rarely consider the potential overlaps.

This was also true of Justice Centre Hong Kong (Justice Centre), a local NGO that provides, inter alia, legal and psychosocial support to asylum seekers and refugees. Acknowledging that there may be various intersections between refugees and victims of human trafficking, Justice Centre undertook a small research project to explore indications of human trafficking amongst its clients. The analysis uncovered multiple indicators across a sample of client files and highlighted different points at which persecution/torture and human trafficking experiences possibly overlap. In examining the blurred boundaries between these categories, particular attention was paid to migrant domestic workers (MDWs), whose experiences are typically considered through the lens of human trafficking but generally not in the context of refugee claims. ${ }^{1}$

This paper, by the authors of the report on the above project, is both a discussion of Justice Centre's research and a reflection on its implications for the NGOs working on human trafficking and refugee issues in Hong Kong. We begin with an overview of the Hong Kong context, briefly describing how the protection systems for refugees and victims of human trafficking operate. We then go on to introduce the methodology and findings of the Justice Centre research, followed by an outline of the existing literature on MDWs in Hong Kong-as migrant workers, victims of human trafficking, as well as asylum seekers and refugees. Next, we explore two case studies from the

See: Justice Centre Hong Kong, Coming Clean: The prevalence of forced labour and buman trafficking for the purpose of forced labour amongst migrant domestic workers in Hong Kong, Hong Kong, 2016, available at: http://www.justicecentre.org.hk/ framework/uploads/2016/03/Coming-Clean-The-prevalence-of-forced-labourand-human-trafficking-for-the-purpose-of-forced-labour-amongst-migrantdomestic-workers-in-Hong-Kong.pdf. 
Justice Centre research, both of women who entered Hong Kong as MDWs and subsequently applied for non-refoulement protection, highlighting some of the ways in which asylum/refugee and human trafficking experiences may intersect. Finally, we use these case studies to consider the implications for NGOs and protection systems in Hong Kong.

\section{The Hong Kong Context}

Hong Kong has a population of approximately 7.4 million people and one of the most liberal visa regimes in the world in terms of ease of entry. ${ }^{2}$ The territory houses a significant number of people considered to be non-residents. Amongst them are some 370,000 MDWs, coming through a formal temporary labour migration programme and constituting 8.9 per cent of the labour force. ${ }^{3}$ There are a number of regulations in place for MDWs: a statutory minimum wage (which is lower than the minimum wage for non-MDWs), ${ }^{4}$ minimum weekly rest hours, paid leave, paid statutory public holidays, paid return trips to their home country, free health care, ${ }^{5}$ parental leave and

2 For example, over 170 nationalities may enter Hong Kong for business or pleasure visits visa-free for a stay ranging from 7 to 180 days. See: Immigration Department, Hong Kong Government, Annual Report 2016, chapter 2, retrieved 25 June 2018, https://www.immd.gov.hk/publications/a_report_2016/en/ ch02.html\#c2.

3 Hong Kong Government, Action Plan to Tackle Trafficking in Persons and to Enhance Protection of Foreign Domestic Helpers in Hong Kong, March 2018, available at: http: / / www.sb.gov.hk/eng/special/pdfs / Action \%20 Plan \%20 to\% 20 Tackle\%20TIP\%20and\%20to\%20Protection\%20FDHs.pdf; Census and Statistics Department, Hong Kong, Hong Kong Annual Digest of Statistics 2017 Edition), retrieved 25 June 2018, https://www.statistics.gov.hk/pub/ B10100032017AN17B0100.pdf.

4 Section 7(3), Minimum Wage Ordinance, Cap 608, available at: https:// www.elegislation.gov.hk/hk/cap608, retrieved 3 May 2018; Hong Kong Government, Hiring Domestic Helpers, available at: https://www.gov.hk/en/ residents/employment/recruitment/foreigndomestichelper.htm.

5 Immigration Department, Hong Kong, Employment Contract for a Domestic Helper Recruited from Outside Hong Kong - English Version, available at: https:// www.immd.gov.hk/eng/forms/forms/id407.html; Section 17, Employment Ordinance, Cap 57, available at: https://www.elegislation.gov.hk/hk/cap57. 
protection, a standard employment contract (two years) ${ }^{6}$ as well as procedures for employment agencies. ${ }^{7}$ Regulations also require MDWs to live in the household of their employer and prevent them from changing employers except under specific, limited circumstances. If a contract finishes or is terminated, they must leave Hong Kong within fourteen days. ${ }^{8}$

There are few protection mechanisms for non-residents in the city. While China is a state party to the Convention relating to the Status of Refugees (1951 Refugee Convention), the treaty has not been extended to cover Hong Kong. Until 2014, the United Nations High Commissioner for Refugees Sub-Office in Hong Kong undertook refugee status determination (RSD) for people claiming protection from persecution. The Hong Kong Government consistently justifies the non-application of the 1951 Refugee Convention on the grounds that they need to maintain immigration control and protect the local labour force. ${ }^{9}$ In the past, a different system applied to victims of torture. The Convention against Torture and Other Cruel, Inhuman or Degrading Treatment or Punishment was extended to Hong Kong in $1992^{10}$ and since then, judicial review has necessitated that the Hong Kong Government implement an administrative torture screening mechanism. ${ }^{11}$

- Immigration Department, Hong Kong, Employment Contract for a Domestic Helper Recruited from Outside Hong Kong - English Version; Section 12, Employment Ordinance, Cap 57.

7 Labour Department, Hong Kong, Code of Practice for Employment Agencies, February 2018, available at: https://www.eaa.labour.gov.hk/_res/pdf/CoP_Eng.pdf.

8 Immigration Department, Hong Kong, Current Limit of Stay, available at: https:/ /www.gov.hk/en/residents/immigration/nonpermanent/limitofstay.htm

9 Comment made by Billy Woo, Principal Assistant Secretary, Security Bureau, Hong Kong in the meeting of the Panel on Security, Legislative Council of Hong Kong on 30 April 2018, webcast available at: https:// webcast.legco.gov.hk/public/zh-hk/SearchResult?MeetingID=M18040019.

10 Legislative Council Secretariat, Review of the Torture Claim Screening Mechanism, Background brief prepared for the Panel on Security for the special meeting on 29 September 2009, 23 September 2009, available at: http://www.legco.gov.hk/ yr08-09/english/panels/se/papers/se0929cb2-2514-2-e.pdf.

11 Sakthevel Prabakar v Secretary for Security [2004] 7 HKCFAR 187, available at: http://www.hklii.hk/cgi-bin/sinodisp/eng/hk/cases/hkcfa/2004/ 43. html? stem $=$ \&synonyms $=$ \&query $=$ title $($ Sakthevel $\% 20$ Prabakar $\% 20$ and $\% 20$ Secretary $\% 20$ for $\% 20$ Security) $\% 20$ OR $\% 20$ ncotherjcitationtitles(Sakthevel $\% 20$ Prabakar $\% 20$ and $\% 20$ Secretary $\% 20$ for $\% 20$ Security) 
In March 2014, the Hong Kong Government began operating the Unified Screening Mechanism (USM), integrating the systems for the determination of torture and persecution claims, and assumed responsibility for assessing all claims made for protection within the territory. ${ }^{12}$ Today there are approximately 10,000 people seeking protection in the city from around seventy different countries of origin. ${ }^{13}$ However, access to protection remains limited. Since the commencement of the USM, Hong Kong has validated only 111 claims ${ }^{14}$ which equals a substantiation rate of about 0.8 per cent ${ }^{15}$ compared to rates of 25 per cent to 62 per cent in other developed jurisdictions. ${ }^{16}$ Moreover, whereas in other countries that undertake individualised RSD, successful applications result in lawful residence (permanent or temporary) with associated rights, successful applications in Hong Kong mean only that

12 UNHCR, 'Sub-office Hong Kong', available at: http://www.unhcr.org/hk/ en/2660-usm-faq-2.html.

13 Immigration Department, Hong Kong, 'Enforcement', available at: http:// www.immd.gov.hk/eng/facts/enforcement.html; Immigration Department, Hong Kong, Response to a data request titled 'Non-refoulement claimants whose claims have been finally determined, Mar 2018', 20 June 2018, available at: https://accessinfo.hk/en/request/non_refoulement_claimants_whose\# outgoing-451; Immigration Department, 'Breakdown of nationality of nonrefoulement claimants', Response to a data request, 12 July 2017, available at: https://accessinfo.hk/en/request/breakdown_of_nationality_of_non.

${ }_{14}$ Immigration Department, Hong Kong Government, 'Enforcement'; Security Bureau, Hong Kong, Response to a data request titled 'Non-refoulement claims substantiated/allowed at first instance and appeal', 20 October 2017, available at: https://accessinfo.hk/en/request/non_refoulement_claims_substanti; Hong Kong Government, 'LCQ4: Torture claims', press release, 7 May 2014, available at: http://www.info.gov.hk/gia/general/201405/07/P201405070624.htm

15 Ibid.

16 For example, the substantiation rates in the United Kingdom, Germany and Canada are 28\%, 25\% and 62\% respectively. See: Asylum Tables, volume one on Home Office, United Kingdom, 'How many people do we grant asylum or protection to?', 21 March 2018, available at: https://www.gov.uk/government/ publications/immigration-statistics-october-to-december-2017/how-manypeople-do-we-grant-asylum-or-protection-to; United Nations High Commissioner for Refugees (UNHCR), 'Country Update: Germany | Q1 2018', 13 November 2017, available at: http://www.unhcr.org/dach/wp-content/ uploads/sites/27/2018/03/Factsheet_Germany_O1_2018.pdf; UNHCR, 'Population Statistics', http://popstats.unhcr.org/en/asylum_seekers. 
people will not be returned to their countries of origin (non-refoulement). They are not given any form of lawful residence and can only apply for sixmonth permits to work, granted at the discretion of the Director of Immigration. ${ }^{17}$

The situation with human trafficking is equally troubling. Although China is a signatory to the Protocol to Prevent, Suppress and Punish Trafficking in Persons Especially Women and Children, Supplementing the United Nations Convention against Transnational Organized Crime, 2000 (UN Trafficking Protocol), it has not been extended to cover Hong Kong. Currently, legislation defines human trafficking only in terms of transnational sex work ${ }^{18}$ without requiring any element of force, fraud, or coercion. ${ }^{19}$ In 2017, nine victims of human trafficking were identified and another three were identified in the first four months of $2018 .^{20}$ In contrast, Justice Centre's primary research estimated that the prevalence of human trafficking amongst MDWs in Hong Kong was approximately 2.4 per cent, or around 8,000 people. ${ }^{21}$ Despite moves to develop an action plan to tackle human trafficking that includes new guidelines and an enhanced mechanism for victim identification and referral, ${ }^{22}$ the government continues to assert that there is no sign that Hong Kong is being actively used as a destination or transit point for human trafficking, or that human trafficking is a widespread or prevalent problem in the city. ${ }^{23}$

To the extent that systems for protection from persecution or torture and for victims of human trafficking exist in Hong Kong, they operate separately, including in the work of NGOs. Refugees are typically imagined as those fleeing political persecution while human trafficking is largely considered to be

17 Section 37ZX, Immigration Ordinance, Cap. 115, available at: https:// www.elegislation.gov.hk/hk/cap115.

18 Section 129, Crimes Ordinance, Cap. 200, available at: https:// www.elegislation.gov.hk/hk/cap200. The Hong Kong legislation refers to 'prostitution'.

19 Ibid.

20 Heidy $\mathrm{Ng}$ (for Secretary for Security), Response to access to information request 'Human trafficking victims identified', 3 July 2018, available at: https:// ccessinfo.hk/en/request/human_trafficking_victims_identi\#incoming-773.

${ }^{21}$ Justice Centre Hong Kong, Coming Clean.

22 Hong Kong Government, Action Plan to Tackle Trafficking in Persons and to Enhance Protection of Foreign Domestic Helpers in Hong Kong.

23 Ibid. 
affecting MDWs and sex workers. ${ }^{24}$ Theoretically, when experiences of being trafficked amount to persecution or torture risks, these should be considered in the evaluation of non-refoulement claims, but the Hong Kong Government does not maintain data about the numbers of such cases. ${ }^{25}$

\section{Methodology}

In 2016, Justice Centre undertook research to explore what indicators of human trafficking might be present in its client files of asylum seekers and refugees. These files had previously only been considered in the context of persecution or torture claims. To begin with, we conducted a series of interviews with local and international experts, including NGO staff, for background information and to develop a framework for analysing client files. We also used these interviews to learn how NGOs responded to victims of human trafficking seeking non-refoulement protection.

Ultimately, the analysis framework consisted of indicators of the act, means, and purpose elements defined in the UN Trafficking Protocol. These were derived from Operational Indicators of Trafficking in Human Beings (2009) and Hard to See, Harder to Count (2012) published by the International Labour Organization, ${ }^{26}$ as well as Forced Marriage as a Form of Human Trafficking by the South Asian Women's Centre in 2014. ${ }^{27}$

${ }^{24}$ For example, Amnesty International published a report in 2013 arguing that the recruitment and working conditions for many MDWs from Indonesia were tantamount to human trafficking. Justice Centre's own research only examined trafficking amongst MDWs. Recent press stories highlight the experiences of women entering Hong Kong believing they would be employed in domestic work but were forced into sex work to pay the costs of mounting debts; see: S Yu 'Forced Smiles Mask Pain of Hong Kong's Trafficked Bar Girls', Thomson Reuters Foundation, 28 February 2017, available at: http://news.trust.org/item/ 20170301010631-hi4fe/.

25 Immigration Department, 'Non-refoulement claims of victims of human trafficking', Response to a data request, 8 May 2017, available at: https:// accessinfo.hk/en/request/non_refoulement_claims_of_victim\#incoming-466

26 International Labour Organization, Operational Indicators of Trafficking in Human Beings, ILO, Geneva, 2009; International Labour Organization, Hard to See, Harder to Count, ILO, Geneva, 2012.

27 South Asian Women's Centre, Forced Marriage as a Form of Human Trafficking, 2014, available at: http://www.sawc.org/wp-content/uploads/2015/04/ Forced-Marriage-as-a-Form-of-Human-Trafficking-Resource-Guide.pdf. 
Justice Centre had over 1,000 case files but to ensure findings were relevant to the current regime in Hong Kong, only clients who registered with Justice Centre after the USM was introduced were sampled (roughly half of the files). The cases considered for the sample also needed to contain at least one of the following to ensure sufficiency of information: (i) a Justice Centre assessment form, (ii) a testimony, (iii) an interview transcript provided by the Immigration Department, or (iv) a notice of determination of the Immigration Department or Torture Claims Appeal Board. Since the objective of the research was to study the protection needs of those who were using or had used the USM, we did not limit the included files to cases which had been substantiated. Instead, the sample also covered case files of rejected claims as well as some still in progress. Sampled cases thus illustrate accounts of persecution and/or torture, irrespective of whether these have been legally recognised as such. Finally, clients had to consent to their data being used for research purposes. Based on these criteria, we employed convenience sampling, choosing the first fifty case files that met our criteria in chronological order.

Capturing experiences prior to arrival in Hong Kong, eleven of the fifty files triggered at least one indicator of each of the act, means and purpose elements of human trafficking. ${ }^{28}$ None of the cases prompted each of the act, means and purpose elements for events that occurred in Hong Kong. Only four of the sampled files included any data about experiences of work in Hong Kong, which limited our ability to assess human trafficking indicators.

The case-file analysis was supplemented with client interviews if their file had triggered human trafficking indicators and they consented to a follow-up. Four clients agreed to participate. The interviews were semi-structured and covered a range of topics including the mode of arrival in Hong Kong; potential experiences of exploitation in the home country or in Hong Kong; and possible abuse of vulnerability by smugglers, agents or other third parties, which might not have been included in their case files.

There are a number of limitations to the study. Due to capacity constraints, we were only able to analyse fifty files and interview four clients. The research is thus exploratory only and far from exhaustive; hence, no definitive conclusions should be drawn.

28 The different elements were not necessarily related to the same experience or incident and significantly more investigation would be required to establish if the client had in fact been a victim of trafficking and whether these experiences triggered their flight to Hong Kong. 


\section{Migrant Domestic Workers as Victims of Human Trafficking or Refugees}

There is extensive literature on MDWs in Hong Kong, ${ }^{29}$ a comprehensive review of which is beyond the scope of this article. Still, it is helpful to outline some of the ways in which migrant domestic work, predominantly performed by women, is examined in the context of human trafficking and asylum. Studying migration and trafficking of Indonesian women, Rebecca Surtees argues that MDWs are vulnerable to human trafficking through the intersection of the recruitment process (which can involve deception about the nature and conditions of work, and the incurring of debts for the costs of recruitment) with the conditions of work once in employment. Surtees notes that 'there is great potential for problems amongst domestic workers given that they are isolated in employers' homes, unable to rely on others as either witnesses or sources of support and protection'. ${ }^{30}$ Due to isolation in individual households, they are vulnerable to exploitation and human trafficking.

Bridget Anderson argues that domestic work is qualitatively different from other forms of work due to the unequal power relations between the worker and the employer. ${ }^{31}$ She maintains that the migrant status of the MDW further compounds this inequality, noting that in places where they are tied to an employer by their immigration status (as in Hong Kong), they are legally dependent on their employer; and where they live-in (again as in Hong Kong), the employer literally controls all aspects of their life. This dependency reinforces the unequal power relationship between the MDW and the employer, creating fertile grounds for exploitation and abuse. ${ }^{32}$

29 See for example, G Chia, 'Focussing the Familiar? Locating the foreign domestic worker in postcolonial Hong Kong discourse', Cross-Sections, vol. viii, 2012, pp. 1-12; S Chiu, A Stranger in the House: Foreign domestic helpers in Hong Kong, Hong Kong Institute of Asia-Pacific Studies \& Chinese University of Hong Kong, 2005; V Wee and A Sim, 'Hong Kong as a Destination for Migrant Domestic Workers' in S Huang, BSA Yeoh and NA Rahman (eds.), Asian Women as Transnational Domestic Workers, Marshall Cavendish Academic, 2005, pp. 175209; N Yellan et al., "We Spend More Time with the Children than They Do

...": Education, care and the work of foreign domestic workers in Hong Kong', Globalisation, Societies and Education, vol.11, issue 4, 2013, pp. 443-458.

30 R Surtees, 'Female Migration and Trafficking in Women: The Indonesian context', Development, vol. 46, issue 3, 2003, p. 100.

31 B Anderson, Doing the Dirty Work? The global politics of domestic labour, Zed Books, London, 2000, p. 121.

32 Ibid, p. 177. 
Moreover, Nicole Constable argues that two immigration regulations in Hong Kong-the live-in requirement and the rule that MDWs have to leave within fourteen days of the completion or termination of contracts - make them particularly vulnerable and ensure that 'many prefer to put up with poor or illegal working conditions rather than suffer the financial hardship of pursuing legal action or returning home'. ${ }^{33}$ Thus, as Hans Ladegaard notes, notwithstanding legislation designed to protect MDWs rights in Hong Kong, many are exploited, assaulted and abused. ${ }^{34}$ He maintains that their work is not only devalued, but that the 'blatantly racist discourses' regarding MDWs are 'considered legitimate and natural'. ${ }^{35}$ These two factors combine to facilitate the abuse and exploitation of MDWs and at the same time allow the general public in Hong Kong to insist that stories of their abuse 'are untruthful or grossly exaggerated'. ${ }^{36}$ Ladegaard concludes that Hong Kong 'is a society that welcomes [MDWs] as workers but not as human beings. ${ }^{37}$

There is less research on MDWs and asylum. During his fieldwork with asylum seekers in Hong Kong, Francesco Vecchio noted that 'a number of domestic helpers were resorting to seeking asylum with the Immigration Department in order to prolong their stay in the territory'. ${ }^{38}$ Vecchio's concern is with the survival strategies of those seeking asylum in Hong Kong and, in particular, with the informal and illegal work undertaken by (mostly male) asylum seekers. He does not enter into a discussion of the 'genuineness' of the asylum claims of former MDWs, or of what might constitute a 'genuine' claim for asylum in such cases. Instead, he examines the connection between asylum and illegal work, noting that former MDWs sometimes continue in informal domestic work after they have submitted a claim for asylum. ${ }^{39}$ Vecchio remarks, however, that a number of his non-refugee research participants expressed concern that former MDWs and their asylum-seeking boyfriends were 'exploiting the system'. ${ }^{40}$ These respondents were alarmed that MDWs were 'shelter[ed] from deportation by claiming asylum' after becoming pregnant. ${ }^{41}$

33 N Constable, Maid to Order in Hong Kong: Stories of migrant workers, $2^{\text {nd }}$ ed., Cornell University Press, 2007, p. 212.

34 H J Ladegaard, The Discourse of Powerlessness and Repression: Life stories of domestic migrant workers in Hong Kong, Routledge, 2016, p. 3.

35 Ibid, p. 119.

36 Ibid, p. 142.

${ }^{37}$ Ibid, p. 119.

38 F Vecchio, Asylum Seeking and the Global City, Routledge, 2015, p. 178.

39 Ibid, p. 178-9.

40 Ibid, p. 145.

41 Ibid. 
Constable has also written about MDWs claiming asylum in Hong Kong. She examines asylum claims used as a strategy by those who become pregnant and try to secure a legal title to stay in the city. ${ }^{42}$ Constable does not focus on the specific nature of the claims former MDWs might make. However, she does analyse how their claims are perceived by NGO staff in comparison with the claims of 'political refugees', ${ }^{43}$ noting that there is an impression that 'real' refugees 'file claims immediately upon entering the country; and that they do not enter Hong Kong as a [...] domestic worker' before declaring their need for protection. ${ }^{44}$ To our knowledge, therefore, there has been little substantial investigation into the refugee-trafficking nexus in Hong Kong or where and how people who enter the territory as MDWs may face persecution and/or torture risks.

\section{Migrant Domestic Workers as Victims of Trafficking and Refugees?}

Of the four clients who consented to interviews for our research, two had entered Hong Kong as MDWs. As argued elsewhere, the categories of refugee and victim of human trafficking are 'not mutually exclusive [and such] experiences can best be understood along a continuum, with individuals occupying multiple "identities/statuses" at different stages of their lives'. ${ }^{45}$ This is demonstrated in the two Justice Centre case studies. ${ }^{46}$

Rose came from a very poor family in a rural part of Asia. Her parents had acquired large debts and, to repay the debts, Rose's father had forced her to marry his creditor, Aman. Rose, although still a child at the time of the marriage, had to work in the home and on the farm of Aman's family for 16 hours a day. She was given little food and was often hit, kicked and smacked by Aman and his relatives. Aman also frequently raped her and threatened to kill her, claiming she had been sold to him. Rose's parents attempted to mediate the situation and sought help from community leaders but their attempts

${ }^{42}$ N Constable, Born Out of Place: Migrant mothers and the politics of international labor, HKU Press, Hong Kong, 2014, p. 184.

43 Ibid.

44 Ibid, pp. 190-191.

45 A Brunovski and R Surtees, Vulnerability and Exploitation along the Balkan Route: Identifying victims of human trafficking in Serbia, Fafo, Oslo, 2017, p. 12.

46 All names have been changed to protect the clients' privacy and safety. 
were not successful. One of Rose's neighbours had worked in Hong Kong as a MDW and introduced a broker to Rose's parents. Rose's parents then borrowed money to pay the broker and the employment agency to arrange work for Rose in Hong Kong. Rose's story suggests that she was trafficked for forced marriage and labour while still a child. Still, her flight from this situation was not undertaken as a 'refugee' or a 'victim of human trafficking' but as a 'labour migrant'.

Before she travelled to Hong Kong, Rose stayed with the employment agency for several months for training. During this time, Aman could not find her and instead attacked her family. In her first contract in Hong Kong, Rose earned less than the minimum allowable wage and had to repay the employment agency training fees, keeping only about USD 100 every month. Neither she nor her parents could repay their original debt to Aman, and he continued to harass and attack her parents. Eventually, her employer terminated her contract after Aman called the house repeatedly to ask for money. Rose then worked for another four employers in Hong Kong. Starting from her second employment contract, she was paid the minimum allowable wage and could remit money home to repay her recruitment debt. Still, she was unable to repay her parents' original debt to Aman.

Rose worked for more than seven years in Hong Kong. After her last employment contract ended, she again found a new employer but he failed to prepare a contract for her in time. Rose requested that the Immigration Department extend her working visa in order to allow her to process the required documentation but the Department extended her visa for one day only. Rose was unable to submit the documents before the visa expired. Fearing that Aman would kill her because she would not be able to repay the money her parents owed him, she remained in Hong Kong, 'over-staying' and effectively becoming 'irregular'.

While in this 'irregular' state, Rose became pregnant, radically changing her needs and decreasing the viability of her status as an overstayer. In addition, it made Rose unemployable as a MDW. Even if the Immigration Department were to allow her to be eligible for an employment visa after overstaying, she would have to live with her employer. However, there are few employers who would be willing to host a MDW accompanied by an infant. With a son born out of marriage, Rose now had an additional fear about returning home- the fear of not being accepted by her family and community. Seeking the assistance of a local NGO, she learnt about the opportunity to make a non-refoulement claim. With neither flight nor work being feasible options, Rose found that her only chance of remaining in Hong Kong lay in invoking the non-refoulement 
principle. Her initial application for protection was rejected and she was appealing the decision at the time of the interview.

The complexities of an individual's experiences when compared with bureaucratic categories are also demonstrated by the case of Bibi. The murder of a family member brought her family into dispute with a politically influential figure. After contacting the police, Bibi suffered severe sexual abuse by public officials and faced death threats from the politically influential figure. Afraid for her life, she sought help from a family friend, Taylor, who suggested that she travel to Hong Kong to work as a MDW. Taylor organised everything for Bibi: her passport, visa, the employment contract, and her plane ticket. Bibi's mother took out a loan to cover the costs of travelling to Hong Kong.

Once in Hong Kong, Bibi found herself working for 21 hours a day with only a few hours off on Sundays. She had to repay Taylor while the employer underpaid her, leaving her with less than USD 50 a month. Even though she disliked the working conditions and was exhausted, Bibi was reluctant to quit. She did not think that she had fully repaid her recruitment debt; was worried that she did not have enough money to support herself in Hong Kong without a job; and was scared that she would be killed if she returned home. Before the two-year contract was finished, however, Bibi decided that she could not take it any longer and quit. With the assistance of a local NGO, she lodged a case against her employer with the Labour Tribunal to claim back her withheld wages. She was partially successful; the Labour Tribunal awarded her a small percentage of the wages owed to her and the money for a plane ticket home. Not knowing anything about her right to protection, Bibi did not tell the NGO or the Labour Tribunal that she feared returning home. For Bibi, what had happened to her at home was irrelevant to the Labour Tribunal process, and the NGO's goal was to enable her to use the available redress avenues for labour issues. From the moment Bibi terminated her employment contract and for the duration of her case in the Labour Tribunal, she was not legally allowed to work and relied on the assistance of NGOs.

However, Bibi was still too afraid to go home. When her visa expired, she decided to remain in Hong Kong. With the support of a friend and assistance from some churches, Bibi survived for a year in Hong Kong as an overstayer. She was eventually caught by the police and arrested. Placed in a detention centre, she was informed by the Immigration Department staff of the possibility to make a claim for non-refoulement protection as a victim of torture. Her initial claim was rejected as was her subsequent appeal/petition with the Torture Claims Appeal Board. She was challenging the Torture Claims Appeal Board decision by way of judicial review at the time of the interview. 


\section{NGO Responses to Migrant Domestic Workers Seeking Protection}

As noted in the literature review above, Rose and Bibi's initial status as migrant workers may well raise doubts about the 'genuineness' of their refugee claims. Constable argues that former MDWs who submit non-refoulement claims 'are often regarded with scepticism and criticism' by NGO staff. ${ }^{47}$ She notes that some staff at NGOs consider them 'less deserving', 'a time-consuming nuisance at best, or undeserving and immoral at worst, taking resources to which they are not entitled'. ${ }^{48}$ In this assessment, submitting applications for protection through the USM is only ever about prolonging their time in Hong Kong and securing some form of support. Whilst USM applications by MDWs might be understandable given their circumstances, they are not 'genuine' cases for protection. ${ }^{49}$

In our interviews with NGO staff, one respondent initially expressed concerns that non-refoulement claims made by potential victims of human trafficking would slow the government's processing of non-refoulement claims overall, making it even harder for refugees to access the limited protection available. ${ }^{50}$ Given the low substantiation rate and the time it can take the government to evaluate claims, concerns about delays are not unwarranted, but they are also influenced by ideas about what constitutes a 'genuine' refugee and seem consistent with Constable's conclusion that some NGO staff do not believe MDWs could need protection in the same way as refugees.

If, however, MDWs have legitimate claims to refugee protection as well as to being victims of human trafficking, what then are the implications for them and for NGOs? As asked by one NGO employee, 'What's in it for the individual MDW?'51 While refugees are afforded extremely limited humanitarian assistance, they are given protection from refoulement and can

47 Constable, 2014, p. 16.

48 Ibid.

49 Ibid, pp. 16-17.

50 Interview on 9 November 2016.

${ }_{51}$ Remark made in an NGO roundtable on Justice Centre Hong Kong's research exploring the nexus between refugees and human trafficking on 25 May 2017 in Hong Kong. 
subsequently apply for resettlement in a third country through the UNHCR. ${ }^{52}$ Hong Kong's substantiation rate is extremely low, the process can take years, and even if a claim is substantiated, the resettlement process is time-consuming and with its own limited chances of success. ${ }^{53}$ For the duration of this process, however, refugees and asylum seekers receive some form of financial and inkind assistance.

At the same time, very few people have been officially identified as victims of human trafficking and it is unclear how the government's new action plan will be implemented in practice and improve victim protection. ${ }^{54} \mathrm{NGOs}$ and international organisations undertake their own screening processes and provide assistance to those whose claims they recognise. In some circumstances, this extends to support to return home, ${ }^{55}$ but without official recognition, this support can never translate into protection from refoulement, even where needed.

Many NGOs in Hong Kong (including Justice Centre) would argue that neither of the two categories and their associated forms of protection is adequate. However, exploring where and how they overlap is essential to securing as

52 Following substantiation of a non-refoulement claim made on persecution risk, UNHCR assists the claimant to be resettled to a third country because the claimant is never awarded residence in Hong Kong.

53 As of 2017, only four non-refoulement claimants have been resettled to a third country or have applications to resettle accepted by a third country since the start of the USM in 2014, according to the Immigration Department. See the webcast of the meeting of the Subcommittee to Follow Up Issues Relating to the Unified Screening Mechanism for Non-refoulement Claims of the Legislative Council of Hong Kong on 27 March 2018, available at: https:// www.legco.gov.hk/yr16-17/english/hc/sub_com/hs54/agenda/ hs5420180327.htm.

${ }^{54}$ For more information about the Action Plan to Tackle Trafficking in Persons, see: Justice Centre Hong Kong, 'Submission to the Panel on Security of the Legislative Council on the Administration's Action Plan to Tackle Trafficking in Persons and to Enhance Protection of Foreign Domestic Helpers in Hong Kong and the Proposed Members' Bill Entitled "Modern Slavery Bill” to Criminalize All Forms of Human Trafficking in Hong Kong', available at: http:// www.justicecentre.org.hk/framework/uploads/2014/03/Justice-Centre-HongKong-Submission-to-Panel-on-Security-human-trafficking-20180605.pdf.

55 The International Organization for Migration (IOM) assists victims of human trafficking with voluntary return and reintegration and resettlement. See: IOM, 'China', retrieved 16 June 2017, https://www.iom.int/countries/china\#rmmoe. 
much protection as possible to vulnerable people outside their country of origin. Individuals who have experienced trafficking and who are also at risk of persecution or torture at home need protection, at least in the form of non-refoulement. The protection offered to refugees in Hong Kong is inadequate, but it is the first step towards safety. In the case of MDWs, access to this protection requires that the Hong Kong Government and NGOs recognise the possibility that they can be refugees as well as victims of human trafficking. It also requires that NGO staff screen for persecution/torture risks among human trafficking victims.

\section{Conclusion}

Didier Fassin contends that refugee status determination is a constant project of interpretation. ${ }^{56}$ Decision makers create 'genuine' refugees through their interpretation and evaluation of the claims made by individuals. The same can be argued for victims of human trafficking. Of course, these interpretative projects are not limited to official decision makers. Julia Dahlvik notes that in the process of determining refugee status, 'asylum claimants, caseworkers, and experts compete over who defines what constitutes a fact, what is worth being documented, and what is credible — and what is not ${ }^{3} \cdot{ }^{57}$ Moreover, as Dahlvik comments, 'power is unequally distributed, usually to the disadvantage of the asylum claimant'. ${ }^{58}$ While they may make claims to a refugee or a victim of human trafficking status, and while they potentially participate in the process through the provision of evidence, MDWs do not control how their story is interpreted, whether it is considered truthful or important.

NGO staff play an important role in the identification of different forms of vulnerability amongst MDWs, and in deciding which forms of protection to try to access in Hong Kong. If we are to fight for better assistance for vulnerable migrants in Hong Kong, then NGOs need to be able to push both interpretive projects, and to reflect on the complex experiences of those trying to access protection.

56 D Fassin, 'The Precarious Truth of Asylum', Public Culture, vol. 25, issue 1, 2013, pp. 39-63, p. 40.

${ }^{57}$ J Dahlvik, 'Asylum as Construction Work: Theorizing administrative practices', Migration Studies, vol. 5, issue 3, 2017, pp. 369-388, p 381.

58 Ibid. 
Jade Anderson is the Head of Research at Justice Centre Hong Kong. She has been working in human rights-based development since 2002 for local and international NGOs in Afghanistan, Pakistan, India and South Africa and with the UNHCR in Australia. She holds a Master's degree in Applied Anthropology and Participatory Development and a Master's in International Development. She is the co-author of the Justice Centre Hong Kong report Coming Clean. Email: jade@justicecentre.org.hk

Annie Li is the Research and Policy Officer at Justice Centre Hong Kong. In this capacity, she conducts research and advocates for laws and policies to protect and promote the rights of asylum seekers, refugees, victims of torture, forced labour and human trafficking, and other people seeking protection. Previously, she has worked at Hong Kong civil society organisations AIDS Concern and Hong Kong Unison in communications and advocacy on healthcare issues, LGBTI rights and racial equality. She holds a Bachelor of Laws degree and a Bachelor of Social Sciences (Government and Laws) degree from the University of Hong Kong. Email: annie@justicecentre.org.hk. 


\title{
Addressing Overlapping Migratory Categories within New Patterns of Mobility in Peru
}

\author{
Cécile Blouin and Emily Button
}

\begin{abstract}
This article reflects on the construction and application of different migratory categories in the Peruvian context, including irregular migrants, refugees, victims of trafficking, and smuggled migrants. Through legal analysis and interviews with key migration actors in the country, the paper explores the ways in which Peru responds to migrants in these different categories, in view of the recent changes in human mobility in the country. The article aims to shed light on the fragmentation of migratory categories and the negative effects this has on migrants' human rights. It is exploratory in nature and serves as a starting point for further debate on the subject.
\end{abstract}

Keywords: trafficking in persons, irregular migration, migrant smuggling, refugees, Peru, categorisations

Please cite this article as: C Blouin and E Button, 'Addressing Overlapping Migratory Categories within New Patterns of Mobility in Peru', Anti-Trafficking Review, issue 11, 2018, pp. 69-84, www.antitraffickingreview.org

This is an open-access article distributed under the terms of the Creative Commons Attribution License (CC-BY). Under the CC-BY license, the public is free to share, adapt, and make commercial use of the work. Users must always give proper attribution to the authors and the Anti-Trafficking Review. 


\section{Introduction}

Migratory patterns affecting Peru have changed drastically since 2017, with the country becoming the main destination for Venezuelan migrants. ${ }^{1}$ The human rights situation in Venezuela has been deteriorating since 2015, including limitations on freedom of speech, an increase in crime rates and severe shortages of food and health services. As a result, large numbers of Venezuelans have been forced to migrate to other countries. ${ }^{2}$ Between January and September 2017, 103,000 Venezuelans crossed the Peruvian border in Tumbes, an average of about 381 migrants a day. ${ }^{3}$ In early 2018, their numbers further increased to 1,000 daily entries. ${ }^{4}$ Peru's government agencies have been overwhelmed with this influx, given their limited financial and human resources.

Peru is also facing challenges in identifying and protecting foreign victims of human trafficking. In 2016, the National Police registered 1,846 trafficked persons in the so-called Sistema RETA. ${ }^{5}$ However, this information is not disaggregated by nationality and only includes cases where charges have been filed against alleged perpetrators. In general, foreign victims of human trafficking are rarely identified in Peru; instead, they are typically treated as irregular migrants and deported back to their countries of origin. ${ }^{6}$

1 UNHCR, Operational Portal, Refugee Situations, Venezuela Situation, retrieved 07 March 2018, https://data2.unhcr.org/en/situations/vensit.

2 Inter-American Commission on Human Rights, 'Situation of Human Rights in Venezuela', OEA/Ser.L/V/II, Doc. 209, 31 December 2017, retrieved 7 March 2018, http://www.oas.org/en/iachr/reports/pdfs/Venezuela2018-en.pdf.

3 International Organization for Migration, Matriz de Seguimiento de Desplazamiento (DTM) - OIM Perú Ronda I, Octubre-Noviembre 2017, retrieved 22 March 2018, https:// reliefweb.int/report/peru/flujo-de-migraci-n-venezolana-1-octubrenoviembre- 2017.

4 UNHCR, Situational Update, Venezuela Situation, January 2018, retrieved 7 March 2018, https://data2.unhcr.org/en/documents/download/62291.

5 Defensoría del Pueblo de Perú, Trata de Personas con Fines de Explotación Sexual en agravio de mujeres adultas, October 2017, retrieved 8 March 2018, http:// peru.unfpa.org/sites/default/files/pub-pdf/I.A-041-2017-ADM-trata-demujeres $\% 281 \% 29$.pdf. The RETA is the Registry and Statistical System of Trafficking in Persons and Related Crimes of the National Police of Peru (PNP).

6 Women's Link Worldwide, Victimas de Trata en América Latina entre la desprotección y la indiferencia, WLW, 2017, p. 28. 
Against this backdrop, this article reflects on the construction and application of different categories surrounding human mobility in Peru. Given that very few analyses exists on the current Peruvian migratory context, the paper is exploratory in nature; it does not aim to draw any definitive conclusions, but rather to serve as a starting point for further research. In particular, the article discusses how relevant state actors conceptualise and respond to the categories of irregular migrants, smuggled migrants, victims of human trafficking and asylum seekers, and identifies key shortcomings and their repercussions for the migrants affected.

The paper derives its arguments based on a bibliographic review of academic materials, reports to the Committee on the Protection of the Rights of All Migrant Workers and Members of their Families (CMW), ${ }^{7}$ other publications from civil society, governmental or international organisations, and inputs from the principal actors working on migration in Peru. The latter were sought through a focus group discussion involving the International Organization for Migration (IOM) and the National Superintendence of Migration (MIGRACIONES), and individual interviews with six people from three public institutions - the Special Commission for Refugees of the Ministry of Foreign Affairs, the Ministry of the Interior, and the Ombudsman's Officeone international organisation, the United Nations High Commissioner for Refugees (UNHCR), and one civil society organisation, Encuentros Jesuit Service of Solidarity. ${ }^{8}$ The questions revolved around the identification of cases and the difficulties related thereto, the possible overlaps in categories and the responses of the state to this reality.

The last report was coordinated by the Institute for Democracy and Human Rights at the Pontifical Catholic University of Peru (IDEHPUCP). It identified a series of problems related to the deprivation of liberty of asylum seekers, who were allegedly being smuggled into the country. The findings in this report were driving factors in the decision to further investigate and analyse the issue of categorical overlaps in the Peruvian context.

8 We had originally planned to conduct a focus group discussion with all relevant actors, but due to scheduling conflicts only two institutions (IOM and MIGRACIONES) were able to attend the meeting. We then organised key informant interviews with most of the remaining actors, but were unable to arrange a meeting with an NGO that works with victims of trafficking. 


\section{Conceptual Framework}

\section{The construction of migrant categories - Theory vs. reality}

Categories applied to migrants have significant impact and result in vastly different responses to the individuals concerned. As Erdal and Oeppen point out, 'Whether someone is discursively presented as an economic migrant or a refugee, for instance, majorly influences their treatment by immigration authorities and humanitarian actors." It is thus important to scrutinise the conceptualisation and application of such categories, especially given that migration is complex and a migrant's motives for leaving a country are varied and may change over time.

A narrow construction of grounds for protection can fail to take into account the fluid nature of migrants' journeys and may lead to infringements of their human rights. Indeed, legislation on asylum in many countries across world regions, including Europe and Latin America, primarily focuses on the concept of persecution, thereby excluding migrants fleeing natural disasters or dire economic conditions. As Zetter notes, the 'causes and patterns of forced migration...are much more complex than in the past.... In complex emergencies many people are caught up in conflict and flee, though they are not persecuted. ${ }^{10}$ For example, a study on Syrian migrants in Europe found that many had decided to move for economic reasons, and not necessarily for fear of persecution. The ongoing conflict in the country had destroyed businesses and forced them to move because no more work was available. ${ }^{11}$ Further, many trafficked persons begin their journeys as voluntary migrants who use the services of smugglers to enter a country before falling into conditions of severe exploitation. ${ }^{12}$

9 M B Erdal and C Oeppen, 'Forced to Leave? The discursive and analytical significance of describing migration as forced and voluntary', Journal of Ethnic and Migration Studies, vol. 44, no. 6, 2018, pp. 981-998, p. 983.

10 R Zetter, 'More Labels, Fewer Refugees: Remaking the refugee label in an era of globalization', Journal of Refugee Studies, vol. 20, no. 2, 2007, pp. 174-176.

${ }_{11}$ H Crawley and D Skleparis, 'Refugees, Migrants, Neither, Both: Categorical fetishism and the politics of bounding in Europe's "migration crisis", Journal of Ethnic and Migration Studies, vol. 44, no. 1, 2018, pp. 48-64, p. 53.

12 M McAdam, 'Who's Who at the Border? A rights-based approach to identifying human trafficking at international borders', Anti-Trafficking Review, issue 2, 2013. 
The flaws of distinguishing between forced and economic migrants are also evident with respect to Venezuelans in Peru. A recent report by the IOM found that 67.5 per cent of them identified economic or employment factors as the principal reasons for leaving their country. ${ }^{13}$ These, however, need to be seen in light of the political climate that contributed to the economic collapse in Venezuela and the resulting job shortage-factors so relevant that UNHCR has called on states to ensure that they uphold the principle of non-refoulement with respect to Venezuelans, consistent with international refugee and humanitarian law. ${ }^{14}$

Such examples demonstrate that 'the decision to leave can only be understood within a wider political economy of forced migration rather than as a response to individualised threats of violence'. ${ }^{15}$ Ignoring or slighting such broader conditions underpinning migration leads to an over-reliance on legally established categories. This has been identified as a fundamental weakness in refugee studies, as it 'limits the extent to which research can offer a radical analysis of the situation of forced migrants that may bring substantive change to their lives'. ${ }^{16}$

\section{Reimagining migrant categories}

Categorising migrants and migration is inevitable; categories 'are the most rudimentary tools in any attempt at generalisation to offer an explanation of migration... [and are] central to processes of social control'; ${ }^{17}$ they are political, open and fluid, rather than fixed, closed constructs. ${ }^{18}$

13 International Organization for Migration.

14 UNHCR, 'Guidance Note on the Outflow of Venezuelans', March 2018, retrieved 22 March 2018, http://www.refworld.org.es/cgi-bin/texis/vtx/rwmain/ opendocpdf.pdf? reldoc $=\mathrm{y} \&$ docid $=5 \mathrm{aa} 07 \mathrm{abd} 4$.

15 Crawley and Skleparis, p. 55.

16 O Bakewell, 'Research Beyond the Categories: The importance of policy irrelevant research into forced migration', Journal of Refugee Studies, vol. 21, issue 4, 2008, pp. 432-453, p. 437.

17 M Collyer and H de Haas, 'Developing Dynamic Categorisations of Transit Migration', Population, Space and Place, vol. 18, issue 4, 2012, pp. 468-481, p. 468.

18 R Jones, 'Categories, Borders and Boundaries', Progress in Human Geography, vol. 33, issue 2, 2009, pp. 174-189, pp. 175, 186. 
As illustrated above, however, the current international legal framework fails to take into account that a person may fall into different migrant categories at different times in the journey, or at the same time. It is therefore important to deal with migrants through the perspective of human rights, ensuring that those in need receive the minimum protections they are entitled to, irrespective of rigid classifications.

Beyond that, it is vital to approach categorisation in a holistic manner and recognise potential overlaps. For example, trafficked persons may be refugees and vice versa; this means that the individuals affected are entitled to the full range of protections and services afforded by both frameworks, as recognised in the relevant international instruments. ${ }^{19}$

\section{International and Peruvian Legal Framework}

Such categorisations in international law are also reflected in the Peruvian context. Whilst the country has introduced a number of acts for the protection of migrants, trafficked persons and others, these generally operate separately and their application remains challenging, as our analysis shows.

In 2017, Peru passed a new general migration law (Legislative Decree 1350), which aligns the country's migration policy with international law and recognises several fundamental rights of migrants, such as access to basic health services, education and justice mechanisms. ${ }^{20}$ Further, the regulation operationalising the law has introduced a series of protections for vulnerable migrants, including victims of domestic and sexual violence, trafficked persons and smuggled migrants, irregular migrants, elderly people, indigenous and tribal people, and LGBTI people, among others. ${ }^{21}$

19 A Gallagher, The International Law of Human Trafficking, Cambridge University Press, New York, 2010, pp. 197-198.

20 Decreto Legislativo No. 1350; Decreto Supremo No. 007-2017-IN.

21 Decreto Supremo No. 007-2017-IN, Art. 227. 
Peru has also taken steps to formalise the status of irregular migrants. Legislative Decree 1350 establishes a humanitarian migration visa (calidad migratoria humanitaria) to be issued by the Ministry of Foreign Affairs, which will be available to extremely vulnerable migrants, including asylum seekers and victims of human trafficking or migrant smuggling. ${ }^{22}$ However, the new humanitarian visa is not yet effective as it lacks the administrative regulation necessary for implementation. The same law further establishes a special migration visa (calidad migratoria especial) requiring authorisation by MIGRACIONES. This visa is extended in exceptional circumstances to foreigners in vulnerable situations, ${ }^{23}$ including — as per a recent directive of MIGRACIONES — victims of trafficking in persons and smuggled migrants. ${ }^{24}$ The groups covered by the humanitarian migration and the special migration visas therefore overlap. The latter, however, does not require additional administrative regulations for implementation and has already been utilised in emergency situations where migrants were in need of protection. ${ }^{25}$

Further, a Temporary Stay Permit (Permiso Temporal de Permanencia or PTP) has been introduced for vulnerable migrants before they receive a special migration visa. Three PTP windows have been opened by the government to date in an attempt to manage the recent influx of Venezuelan migrants to the country. The current PTP process allows Venezuelans who enter the country through

22 Ibid., Art. 29.2(k).

23 Ibid., Art. 230.1 and 230.2.

24 Superintendente Nacional, Resolución de Superintendencia No. 0000357-2017Migraciones, Aprueban la Directiva 'Atención a Victimas de trata de Personas y Tráfico Ilícito de Migrantes', 28 de diciembre de 2017, retrieved 19 March 2018, http:// busquedas.elperuano.pe/normaslegales/aprueban-la-directiva-atencion-a-victimasde-trata-de-perso-resolucion-n-0000357-2017-migraciones-1602482-1/.

25 IDEHPUCP, Informe Alternativo al Comité de Protección de los Derechos de Todos los Trabajadores Migratorios y de sus Familiares Perú, 11 November 2017, p. 13, retrieved 22 March 2018, http://cdn01.pucp.education/idehpucp/wp-content/uploads/ 2017/09/11234252/11-09-final-informe-alternativo-al-comite-de-protecciontrabajadores-migratorios.pdf. 
31 December 2018 to apply for a Temporary Stay Permit. ${ }^{26}$ The PTP is different from other visas because it is targeted at a particular situation and does not grant residency.

Moreover, Peru is party to the 1951 Convention Relating to the Status of Refugees and its 1967 Protocol, and has adopted the expanded definition of the Cartagena Declaration on Refugees, which includes protection in cases of foreign aggression, internal conflicts, severe violations of human rights or other circumstances that have seriously disturbed public order. ${ }^{27}$ Law No. 27891 establishes that, once refugees are recognised as such by the state, they have the same rights and obligations that the Constitution and laws confer on foreign residents. It also stipulates that the Special Commission for Refugees (the main body charged with processing refugee applications) will provide assistance programmes for their integration, resettlement or repatriation. ${ }^{28}$ Whilst there is currently no national plan with respect to refugees, in 2018 the country passed a National Plan on Human Rights, which, among other objectives, aims to guarantee that refugees have access to programmes facilitating their integration and to ensure that asylum seekers are granted emergency health care. $^{29}$

26 Decreto Supremo No. 001-2018-IN Aprueban lineamientos para el otorgamiento del Permiso Temporal de Permanencia para las personas de nacionalidad venezolana. Further, within 24 hours of enacting the latest authorisation of the PTP, 1,700 appointments for obtaining such status had been registered online (UNHCR, Situational Update, Venezuela Situation, January 2018, retrieved 7 March 2018, https://data2.unhcr.org/en/documents/download/62291). It is important to mention that this is the third PTP for Venezuelans approved since 2017: DECRETO SUPREMO No. 002-2017-IN (publicado el 3 de enero de 2017) and DECRETO SUPREMO No. 023-2017-IN (publicado el 29 de julio de 2017). Note that the state has also introduced Temporary Stay Permits for other groups, such as mothers or fathers of permanently disabled minor or adult children of Peruvian nationality (see: Decreto Supremo No. 001-2017-IN Lineamientos para el Otorgamiento del Permiso Temporal de Permanencia para las Personas Extranjeras Madres o Padres de Hijos/as Peruanos/as menores de edad e hijos/as mayores de edad con discapacidad permanente).

27 Colloquium on the International Protection of Refugees in Central America, Mexico and Panama, Cartagena Declaration on Refugees, 22 November 1984, part III, para. 3.

28 Ley No. 27891 (Ley del Refugiado), 20 December 2002, Art. 3.

29 Plan Nacional de Derechos Humanos 2018-2021, p. 144 (approved through Supreme Decree 002-2018-JUS). 
Further, the Peruvian definition of human trafficking as contained in Law No. 28950 is largely aligned to that of the UN Trafficking Protocol. The act and its administrative regulation also establish that the state will provide victims with safe repatriation and various other services such as temporary accommodation, and medical, psychological, social and legal assistance. In addition, the National Plan against Trafficking in Persons (2017-2021) sets forth measures to guarantee care for victims of trafficking, including safeguards for the protection of children and adolescents. ${ }^{30}$ Except in referencing the humanitarian migration visa, however, it does not deal with the particular situation of foreign trafficked persons, their identification and reintegration. Instead, trafficking victims from abroad are more specifically included under the separate National Policy against Trafficking in Persons and Its Attendant Forms of Exploitation. Introduced in 2015, the policy's general guidelines require that the state strengthen the comprehensive care and protection of national and foreign trafficked persons, and ensure coordinated and concerted action by all agents through immediate and appropriate multisectoral assistance. ${ }^{31}$ However, the National Policy, unlike the National Plan, does not establish indicators for monitoring the progress of its implementation.

Peru is also party to the Protocol against the Smuggling of Migrants by Land, Sea and Air, which stipulates that migrants not be liable to criminal prosecution for having been smuggled. ${ }^{22}$ The Protocol further provides that states must take measures to afford migrants appropriate protection against violence, and to assist those whose lives or safety have been endangered by reason of having been smuggled. ${ }^{33}$ It is important to note that the Protocol refers to smuggled migrants as 'objects of the offence', rather than 'victims of the offence', on the premise that they consent to being smuggled and should thus only be considered victims if they suffer other crimes in the process, such as kidnapping or physical violence. ${ }^{34}$ Peruvian legislation applies a more generous approach.

30 Decreto Supremo No. 017-2017-IN Decreto Supremo que apruebael Plan Nacional contra la Trata de Personas 2017-2021.

31 Ministry of Justice, Decreto Supremo No. 001-2015-JUS, Aprueban Política Nacional frente a la Trata de Personas y sus formas de explotación.

32 UN General Assembly, Protocol Against the Smuggling of Migrants by Land, Sea and Air, Supplementing the United Nations Convention Against Transnational Organized Crime, 15 November 2000, Art. 5.

33 Ibid., Art. 16.

34 C Blouin, 'La Normativa Peruana en Materia de Tráfico de Migrantes a la Luz del Derecho Internacional: ¿Hacia una protección de los derechos de las personas migrantes?', Revista Espiga, vol. 17, no. 34, 2017, pp. 215-230. 
The country's immigration law (Legislative Decree 1350) speaks of 'victims of smuggling', and Law No. 28950 and its administrative regulations grant smuggled migrants, children and pregnant women the right to assistance from the state. ${ }^{35}$ However, the country is lacking a national plan on migrant smuggling and separate guidelines for identifying and providing assistance to smuggled migrants, although some coverage is provided through the national human rights protection framework. ${ }^{36}$

\section{Key Problems in the Application of Migrant Categories in Peru}

\section{Cases of overlapping categories}

Through both primary and secondary research for this paper, we have identified two instances of overlapping migratory categories in the Peruvian context: between smuggled migrants and asylum seekers, and between foreign trafficked persons and irregular migrants.

According to the Ministry of Foreign Affairs and information shared in the Inter-Sectoral Working Group for Migration Management, ${ }^{37}$ authorities have observed migrants arriving at the Jorge Chávez International Airport in Lima via smuggling networks and then applying for refugee status to enter the country, as advised by their smugglers. ${ }^{38}$ Once in Peru, they reportedly disappear and never formalise their claims. In response, the state has decided to deny asylum seekers entry and to process refugee claims at the airport, arguing that most applications for asylum turn out to be unfounded. A report documenting such cases found that, from 2015 until the first half of 2017, twenty-one asylum seekers, including two girls, were detained at the airport for periods between four and twenty days. ${ }^{39}$ This practice contravenes key standards in

35 Decreto Supremo No. 001-2016-IN, Art. 50.1.

36 Plan Nacional de Derechos Humanos 2018-2021, p. 144.

37 IDEHPUCP participated in the meeting of 26 June 2017 in which this problem was presented by the Ministry of Foreign Affairs and MIGRACIONES.

38 We do not have precise information about the cases. Apparently, in some cases migrants did not have the required visa and in others they had a forged document. It has not been confirmed whether the smugglers accompanied the migrants on their journey.

39 IDEHPUCP 2017, pp. 15-17. 
protecting the rights of migrants ${ }^{40}$ and is particularly worrying as it concerns applicants for refugee status. ${ }^{41}$ In this case, it appears that the state is applying the less protective category of smuggled migrant over that of asylum seeker.

Further, according to the latest figures published by the NGO CHS Alternativo, ten foreign trafficked persons were identified in the Sistema RETA in the first half of $2017,{ }^{42}$ while MIGRACIONES reported that it dealt with four cases of human trafficking in all of 2017. ${ }^{43}$ MIGRACIONES has also granted a first-ever special migration visa to a foreign trafficked person ${ }^{44}$ and, aware that there are more such cases, expects the numbers to increase following more concerted state efforts to implement the National Plan against Trafficking in Persons. $^{45}$

In both cases, the misapplication of migratory categories and the negative repercussions for the individuals concerned appear rooted in two key factors: the fragmentation of institutional mandates and the lack of regulations for policy implementation.

40 General Comment No. 2 on the rights of migrant workers in an irregular situation and members of their families raised by the Committee on the Protection of the Rights of All Migrant Workers and Members of their Families (CMW), retrieved 13 August 2018, http://www2.ohchr.org/english/bodies/cmw/docs/ CMW_C_GC_2_ENG.PDF.

41 The 1951 Refugee Convention, in its article 31, prohibits sanctions such as detention, imposed on refugees only because of their illegal entry or presence.

42 Capital Humano y Social Alternativo, V Informe Alternativo Principales Hallargos 2016-2017 Balance de la sociedad civil sobre la situación de la trata de persona en el Perút 2016-2017, CHS Alternativo, Lima, 2017, p. 28, retrieved 13 August 2018 http:// chsalternativo.org/balances-e-informes-alternativos/669-principales-hallazgos-delv-informe-alternativo-2016-2017/file.

43 Superintendencia Nacional de Migraciones, Presencia de Inmigrantes en Situación de Vulnerabilidad en el Perú. Estudio preliminar realizado desde una perspectiva de género, 2018, retrieved 19 March 2018, https://www.migraciones.gob.pe /wp-content/uploads/2018/03/Presencia_inmigrantes_situacion_vulnerabilidad_Peru.pdf. We cannot say if these four cases are included in the ten cases recorded by RETA in the first half of 2017 because registrations of trafficking cases by different agencies are not crosslinked. See: Mac Gillivray et al., Manual de Capacitación para Operadores de Justicia Durante la Investigación y el Proceso Penal en Casos de Trata de Personas, IDEHPUCP, Lima, 2017, p. 23.

44 Superintendencia Nacional de Migraciones, 2018.

45 Ibid., p. 31. 


\section{Fragmentation of institutional mandates}

In Peru, different government institutions are responsible for different categories of migrants, resulting in a fragmented response to migration. The Ministry of the Interior deals with human trafficking and migrant smuggling, the Ministry of Foreign Affairs is in charge of asylum claims, ${ }^{46}$ and MIGRACIONES oversees broader immigration matters. The 'Vulnerability Office' created by MIGRACIONES in 2016 is the only institution charged with an integrated approach to vulnerable migrants ${ }^{47}$ and as such may have contact with the entire migrant population (including victims of human trafficking, refugees and smuggled migrants).

However, a representative of MIGRACIONES highlighted in our meeting that '[the agency] has not been seen by [other institutions] as a key actor in the area of trafficking in persons; the victim assistance framework does not include the MIGRACIONES office' (translation by the authors). The exclusion of MIGRACIONES from cases involving potential foreign victims of trafficking means that the individuals concerned cannot receive a residence permit and remain therefore excluded from some of the protections offered by the state, in particular from health, education and most other governmental services. In other words, the fragmentation of institutional mandates and the resulting lack of cooperation between state agencies mean that foreign victims of trafficking are treated as irregular migrants rather than victims.

Moreover, whilst there are two inter-institutional mechanisms seeking to facilitate coordination, namely the Inter-Sectoral Working Group for Migration Management ${ }^{48}$ and the Permanent Multisectoral Commission against Trafficking in Persons and the Illicit Smuggling of Migrants (CMNP TP-

46 Decreto Supremo N 135-2010-RE, Reglamento de Organización y Funciones del Ministerio de Relaciones Exteriores, 18 December 2010, Art. 99.

47 Superintendencia Nacional de Migraciones 2018, pp 11-12. According to an interview we conducted with an official of the Vulnerability Office, the creation of a Sub-Directorate of Migration Integration is pending, which will seek to support migrants in Peru, especially those in vulnerable situations.

48 Decreto Supremo no 067-2011-pcm, Crean la Comisión Multisectorial Permanente 'Mesa de Trabajo Intersectorial para la Gestión Migratoria'. The IDEHPUCP, with which the first author of this paper is affiliated, is a member of the coordination commission that brings together civil society institutions of the intersectoral working group for migration management. 
TIM) ${ }^{49}$ these are not related to one another and do not have procedures for the exchange of information. In addition, neither mechanism deals with cases of asylum, reflecting the previously mentioned dichotomy between refugees and other migrants and thereby undermining inter-institutional coordination between the Ministry of Foreign Affairs and MIGRACIONES. During the interviews for this paper, a UNHCR representative noted that 'the line of work on the subject of asylum seekers and refugees is understood to be disconnected from mobility issues. The complementarity that must exist between them has not yet been achieved. At the moment there is some awareness that the topic is complex and solutions are being developed, but these are still very young' (translation by the authors).

The interviews conducted with UNHCR, the Ministry of Foreign Affairs and the Ministry of the Interior confirmed that if, for example, the Ministry of Foreign Affairs attends to an asylum seeker, it does not generally consider whether the person may also be a victim of human trafficking and does not refer this person to the Ministry of the Interior. The same applies to the latter, which will not examine whether a victim of trafficking also has a potential claim for refugee status and should thus be referred to the competent authority dealing with such cases. These shortcomings are partly a function of inadequate training on aspects and categories of human mobility beyond their narrowly defined mandates, coupled with deficient structures for referrals to the appropriate institutions. ${ }^{50}$

Each of the above-mentioned institutions tends to focus solely on their particular mandates. This prevents a comprehensive analysis of migration as a complex process and, in some cases as in the two scenarios described above, the identification of individuals that potentially fall into more than one category at the same time.

49 Decreto Supremo N ${ }^{\circ}$ 001-2016-IN que aprueba el Reglamento de la Ley N ${ }^{\circ} 28950$, Ley contra la Trata de Personas y el Tráfico Ilícito de Migrantes, y crea la Comisión Multisectorial de naturaleza permanente contra la Trata de Personas y el Tráfico Il cito de Migrantes. IDEHPUCP is a guest member of this Commission.

50 C Blanco and C Marinelli, 'Victimas de Trata de Personas versus Migrantes en Situación Irregular. Retos y lineamientos para la atención y protección de las víctimas de trata de personas extranjeras en el Perú, Derecho PUCP, no. 78, 2017, pp. 173-198, p. 190. 


\section{Lack of regulations for policy implementation}

The Ministry of the Interior is currently drafting a protocol to provide guidance to MIGRACIONES and the police in dealing with cases of migrant smuggling. ${ }^{51}$ In this, it will be important to ensure that smuggled migrants can obtain residency in Peru, for example through the humanitarian or the special migration visas. ${ }^{52}$ In an interview conducted for this paper, Encuentros Jesuit Service of Solidarity pointed out that, at present, it is unclear whether the public prosecutor first needs to determine that there are sufficient grounds for assuming the crime of migrant smuggling has taken place before a migrant can be considered smuggled and access support. The protocol should therefore provide clear procedural guidance so that smuggled persons can gain access to the protection and assistance to which they are entitled.

Further, while there are various relevant frameworks in Peru for cases of foreign victims of human trafficking (laws, national plans and policies), the country lacks a specialised victim assistance framework for them and has no process for granting them residence status. ${ }^{53}$ MIGRACIONES has adopted a resolution to approve guidelines on how smuggled migrants and victims of trafficking from abroad may access the 'special migration visa" ${ }^{54}$ but these guidelines have not been published. According to a representative of the agency, the procedure to grant this type of visa requires 'self-identification' of a person and supporting documentation, for example a police report in alleged cases of human trafficking. Moreover, it remains unclear what progress has been made, if any, in the development of regulations operationalising the 'humanitarian migration visa'.

51 Ministry of the Interior, Sectoral Protocol on Migrant Smuggling (in process of being drafted by IDEHPUCP).

52 Blouin, p. 227.

53 Blanco and Marinelli, pp. 189-194.

54 Resolución de Superintendencia No. 0000357-2017-MIGRACIONES, Aprueban la Directiva 'Atención a Victimas de Trata de Personas y Tráfico Ilícito de Migrantes', 28 December 2017, retrieved 23 March 2018, http://busquedas.elperuano.pe/ normaslegales/aprueban-la-directiva-atencion-a-victimas-de-trata-de-persoresolucion-n-0000357-2017-migraciones-1602482-1/. 
MIGRACIONES also experiences difficulties in identifying foreign victims of trafficking in border areas, partly because they lack the necessary tools and protocols for such purposes. A representative of the agency highlighted in our interview that in the few cases of this type that they have dealt with, the victims were referred to them by other institutions. Meeting reports of MIGRACIONES note that, at times, their officials encounter individuals that they suspect may have been trafficked, but the agents can only respond by notifying the police, which sometimes appears reluctant to take action. ${ }^{55}$ It is worth exploring whether perceptions of the 'typical' victim being Peruvian, not a foreigner, may lead authorities to more frequently identify foreigners as irregular migrants rather than trafficked persons. ${ }^{56}$

The fact that victims of human trafficking often remain unidentified due to the reasons mentioned above also has direct repercussions for the work of some international organisations. For example, in our focus group discussion, an IOM representative explained that, in order for the agency to assist victims of human trafficking, the state first needs to recognise the person as such after a police report is filed and a criminal investigation opened. However, if the trafficked person does not file a police report, IOM cannot provide services and for this reason the number of victims that are able to access IOM's assistance programme for trafficked persons is very small. ${ }^{57}$

\section{Conclusion}

It is challenging to examine migratory categories while patterns of human mobility are shifting and the relevant regulatory framework is undergoing reform. Such is the case in Peru where difficulties are further compounded by overlaps in the mandates of, and a lack of coordination between, relevant institutions. However, the new realities of migration in the country compel us, more urgently than ever before, to rethink these migrant categories from a holistic perspective and propose comprehensive responses that protect and guarantee the rights of migrants.

55 This was an internal meeting inside MIGRACIONES in November 2017.

56 C Blanco and Marinelli, p. 190.

${ }^{57}$ E Button, A Jáuregui and F Mamani, Informe Trata de Personas en América Latina y El Caribe $165^{\circ}$ Período de Sesiones Comisión Interamericana de Derechos Humanos, IDEHPUCP, Lima, 2017. 
One proposal that arises from our analysis is the need for a truly intersectoral approach to human mobility among the different institutions-one that allows the categories to be understood in an integral way. Another key measure is to develop protocols to operationalise the standards and plans that have already been adopted. Without these interventions, it will be impossible to respond to the various needs of migrants, be they victims of human trafficking, smuggled migrants or others requiring protection.

Cécile Blouin is a senior researcher at the Institute for Democracy and Human Rights at the Pontifical Catholic University of Peru (IDEHPUCP) and teacher at the Faculty of Law and the Human Rights Master Degree at PUCP. She previously worked as consultant for the Office of the United Nations High Commissioner for Refugees. Her research interests include migration and human rights, intersectionality and gender in migration, forced migration, and trafficking and smuggling in Latin America, especially Peru. Email: cblouin@pucp.edu.pe.

Emily Button received her Juris Doctorate from Rutgers Law School, USA. She is an independent researcher focusing on human mobility issues in Latin America, particularly the trafficking of persons and the rights of refugees and other vulnerable populations in the context of migration. Most recently, she was a researcher at the IDEHPUCP. Email emilyannbutton@gmail.com. 


\title{
'What's in a Name?': Mislabelling, misidentification, and the US government's failure to protect human trafficking survivors in the Central American refugee crisis
}

\author{
Katherine Soltis and Rebecca Walters
}

\section{Abstract}

This article explores how competing and overlapping legal classifications such as 'victim of trafficking', 'smuggled migrant', 'illegal alien', and 'refugee' play out in the United States (US) immigration system. In particular, it focuses on the repeated failure of US authorities to identify and protect survivors of human trafficking who were victimised by the smugglers they voluntarily employed in fleeing their home countries - a scenario that is becoming increasingly common in the midst of the Central American refugee crisis. The article draws upon the authors' experience providing direct legal representation to Central American migrants in the US to discuss how misassumptions about this population, a misunderstanding of the relevant legal terminology, and the US government's focus on border security negatively impact the conduct of law enforcement agencies and immigration adjudicators. Due in large part to the US government's increased restrictions on, and criminalisation of, many forms of migration, survivors of human trafficking who are victimised by smugglers often find themselves classified as 'illegal aliens' or 'criminal aliens', and their legitimate claims for protection are frequently dismissed for the irrelevant fact that they initially consented to be smuggled. Such mistreatment and misidentification fail to hold perpetrators accountable, and to offer assistance to populations that the US government has pledged to defend.

Keywords: refugees, border security, $\mathrm{T}$ nonimmigrant status, human smuggling

Please cite this article as: K Soltis and R Walters, “What's in a Name?": Mislabelling, misidentification, and the US government's failure to protect human trafficking survivors in the Central American refugee crisis', AntiTrafficking Review, issue 11, 2018, pp. 85-102, www.antitraffickingreview.org

This is an open-access article distributed under the terms of the Creative Commons Attribution License (CC-BY). Under the CC-BY license, the public is free to share, adapt, and make commercial use of the work. Users must always give proper attribution to the authors and the Anti-Trafficking Review. 


\section{Introduction}

Under US federal law, the legal definitions and procedural screening mechanisms associated with terms such as 'human trafficking', 'human smuggling', and 'illegal immigration' dramatically affect the immigration remedies available to the individuals concerned, and the public benefits and aid programmes they can access. Furthermore, such terms strongly influence how they are perceived and dealt with by US immigration authorities, including US Customs and Border Protection (CBP), US Citizenship and Immigration Services (USCIS), US Immigration and Customs Enforcement (ICE), and other federal government agencies.

Several publications have explored the theoretical and policy implications of the competing and potentially overlapping legal categories applied to human trafficking survivors in the US. ${ }^{1}$ This article, however, offers a unique perspective by drawing from the authors' personal experiences representing low-income migrants ${ }^{2}$ in the Washington, DC metropolitan region, including hundreds

1 See, e.g., J C Hathaway, 'The Human Rights Quagmire of "Human Trafficking”, Virginia Journal of International Law, vol. 49, no. 1, 2008, pp. 1-59; A Gallagher, 'Human Rights and Human Trafficking: Quagmire or Firm Ground? A response to James Hathaway', Virginia Journal of International Law, vol. 49, no. 4, 2009; J Chacon, 'Tensions and Trade-offs: Protecting trafficking victims in the era of immigration enforcement', University of Pennsylvania Law Review, vol. 158, issue 6, 2010, pp. 1609-1653; J Chacon, 'Misery and Myopia: Understanding the failures of U.S. efforts to stop human trafficking', Fordham Law Review, vol. 74, issue 6, 2006, pp. 2977-3040; J Srikantiah, 'Perfect Victims and Real Survivors: The iconic victim in domestic human trafficking law', Boston University Law Review, vol. 87, 2007.

2 The use of the term migrant in this paper captures 'any person who is moving or has moved across an international border or within a State away from his/her habitual place of residence, regardless of (1) the person's legal status; (2) whether the movement is voluntary or involuntary; (3) what the causes for the movement are; or (4) what the length of the stay is', as defined by the International Organization for Migration. As such, the term is not limited to individuals relocating due to seasonal work or for broader economic reasons only, as is sometimes the connotation in the US context. 
of asylum seekers and human trafficking survivors seeking legal protections since the Central American refugee crisis began. ${ }^{3}$

The Central American refugee crisis is rooted in the Northern Triangle, consisting of El Salvador, Honduras and Guatemala. High crime rates perpetrated by gangs (known as maras), domestic abuse and sexual violence have contributed to the displacement of hundreds of thousands of people, predominantly women and children. ${ }^{4}$ According to the United Nations High Commissioner for Refugees, 'From 2011 to 2016, the number of people from the Northern Triangle who have sought refuge in surrounding countries has increased by 2,249 per cent. $^{5}$ In 2014, the US experienced a surge of unaccompanied minors and family units seeking asylum at the southern border ${ }^{6}$ and the numbers have remained high ever since, with 415,191 apprehensions recorded in $2017 .^{7}$

The desperation of many Central Americans to flee their countries of origin, coupled with the US government's enhanced focus on border control and the criminalisation of many forms of migration, has given smuggling networks substantial power over asylum seekers, and has contributed to the growth of an organised criminal industry rampant with exploitation and abuse. Several

3 Throughout the article, our use of the term 'Central American refugee crisis' refers to the surge of Central American asylum seekers requesting protection in the United States starting in 2014 due to legitimate fears of gang-related violence and persecution. Most of these individuals have not been formally classified as 'refugees', but we use this term here to signify our belief that the vast majority of them do have a legitimate fear of return to their countries of origin.

4 United States of America for the Office of the United Nations High Commissioner for Refugees, Central American Refugee Crisis: Families and unaccompanied children are fleeing horrific gang violence, retrieved 7 January 2018, https://www.unrefugees.org/emergencies/central-america/.

5 Ibid.

6 United States Customs and Border Protection, United States Border Patrol Southwest Family Unit Subject and Unaccompanied Alien Children Apprehensions Fiscal Year 2016, 18 October 2016, retrieved 7 January 2018, https://www.cbp.gov/ newsroom/stats/southwest-border-unaccompanied-children/fy-2016.

7 United States Customs and Border Protection, CBP Southwest Border Apprehensions/ Inadmissibles, retrieved 7 January 2018, https://www.cbp.gov/sites/default/ files/assets/documents/2017-Dec/CBP\%20Apprehensions.pdf. 
authors have noted that, even though the US has championed the global fight against human trafficking, the emphasis on border security not only undermines the legal protections afforded to human trafficking survivors, but actually contributes to the phenomenon's rise. ${ }^{8}$ For example, James Hathaway highlights that, 'Indeed, because border crossing is itself more challenging and because smugglers are now subject to internationally mandated criminal sanctions if caught [...] the smuggling business will logically become increasingly attractive to organized crime [...] And more tragically still, if those determined to cross cannot afford the higher prices demanded, they will be more vulnerable to exploitation and even to post-crossing enslavement to repay the smuggling debt.'

The fictional case of Carmen, derived from our professional records, exemplifies the experience of abuse common among migrants from the Northern Triangle. Carmen fled domestic violence in Honduras and employed the services of a smuggler, also known as a coyote or guia, to help her travel to the US, where she planned to seek asylum. In Mexico, the smuggling arrangement transformed into an incident of human trafficking. The coyote was affiliated with a criminal network that held Carmen against her will in both Mexico and Texas for months, and forced her and other migrants to perform labour, including sexual services, to repay an alleged debt even though she had already paid the amount the smugglers had initially requested. Carmen was eventually freed by CBP agents and helped the officers in their investigation; however, she was not given any information about her legal rights as a survivor of human trafficking or as an asylum seeker, was not directed to obtain assistance from relevant US agencies or victim service organisations and was instead placed in removal proceedings.

Carmen's story provides a window into how competing and overlapping classifications play out in the US immigration system. Keeping her case in mind, we begin this paper with a review of US legal definitions and immigration protections that are relevant in the wake of the Central American refugee crisis. Next, based on an analysis of our cases and the screening mechanisms used by Law Enforcement Agencies (LEAs) at the US-Mexico border, we examine how the institutions tasked with the preliminary identification and protection of human trafficking survivors frequently fail to do so in practice, thereby

8 Hathaway, pp. 33-34; Chacon, 'Tensions and Trade-Offs', p. 1612.

9 Hathaway, pp. 33-34. 
impeding the survivors' access to legal rights and protections. Finally, we detail how USCIS, the agency responsible for adjudicating certain claims for immigration relief, often misapplies legal standards and conflates human trafficking and human smuggling.

Although this paper is not based on a systematic review of cases, our grassroots observations may prove useful in illustrating several broader trends in the current US anti-trafficking and border apprehension frameworks, and in highlighting the direct effects of conflicting policies and categorisations on trafficking survivors. When survivors are misidentified, they are stripped of their victimhood in the eyes of immigration authorities, LEAs, and the American public, excluding them from remedies and protections, and preventing their stories from being told. This article aims to tell part of those stories.

\section{Legal Protections and Classifications under US Immigration Law}

Survivors of human trafficking are entitled to significant legal protections and aid programmes in the US. The Trafficking Victims Protection Act (TVPA) and its subsequent reauthorisations, including the 2008 William Wilberforce Trafficking Victims Protection Reauthorisation Act (TVPRA), ${ }^{10}$ aim at combating human trafficking domestically and abroad. Its domestic provisions include the protection of survivors against retaliation by traffickers and the expansion of US law enforcement authority to grant certain immigration remedies to victims.

The Department of Homeland Security (DHS), which encompasses CBP, ICE and USCIS, is the primary government agency tasked with the preliminary identification and protection of trafficking survivors. LEAs wield substantial powers in their ability to assist victims, such as by applying for Continued Presence (CP) on their behalf: a temporary immigration status that provides relief from immigration enforcement actions, work authorisation and access to a variety of public benefits. ${ }^{11} \mathrm{ICE}$ formally adjudicates all CP applications,

10 Pub. L. 110-457, 122 Stat. 5044 (2008).

11 USICE, 'Continued Presence: Temporary immigration status for victims of human trafficking', retrieved 22 August 2018, https://www.ice.gov/doclib/humantrafficking/pdf/continued-presence.pdf. 
which, according to the agency, 'should be submitted immediately upon identification of a victim, regardless of whether or not the victim has cooperated'. ${ }^{12}$ DHS may use CP to further extend protections to victims' family members residing in the US or abroad, in order to ensure their safety and to support survivors in their continued collaboration with a law enforcement investigation or prosecution.

Moreover, USCIS has authority to consider cases for more permanent immigration remedies for survivors. The primary legal immigration remedies under the TVPRA are the T visa and the $\mathrm{U}$ visa-two nonimmigrant visas adjudicated by USCIS that provide a path to permanent residency and citizenship in the US. ${ }^{13}$ Significantly faster processing times and the absence of a required LEA certification make the $\mathrm{T}$ visa a more advantageous form of relief than the $\mathrm{U}$ visa for most clients. The focus of this article therefore is on the $\mathrm{T}$ visa.

The statutory protections for human trafficking survivors are codified in the Immigration and Nationality Act (INA) \$101(a)(15)(T) and 214(o). ${ }^{14}$ To qualify for a T-1 nonimmigrant visa, an applicant must show that he/she: (1) is or has been a victim of a severe form of trafficking in persons; (2) is in the US on account of such trafficking; (3) has complied with any reasonable requests for assistance in the investigation or prosecution of trafficking; and (4) would suffer extreme hardship involving unusual and severe harm upon removal from the United States. ${ }^{15}$ The term 'severe form of trafficking in persons' is

12 Ibid.

13 The $\mathrm{U}$ visa is available to victims of certain forms of criminal activity, including domestic violence, human trafficking, sexual assault and other crimes. It requires a certification from a law-enforcement official, prosecutor, judge, or other federal or state authorities that the applicant was a victim of a qualifying criminal activity and has been or is likely to be helpful in an investigation or prosecution. This required certification poses a hurdle to obtaining immigration relief because LEAs are not required to sign these certifications. The $\mathrm{U}$ visa has an annual cap of 10,000 visas and a current backlog of 200,000 applications. The T visa, in comparison, is available only to 'victims of a severe form of trafficking in persons', as defined under US federal law. No law enforcement certification is required, although victims generally must cooperate with law enforcement unless they are minors or have suffered extreme trauma. There is an annual cap of 5,000 visas, which has never been reached.

148 U.S.C. $\$ \$ 1101(\mathrm{a})(15)(\mathrm{T})$ and $1184(\mathrm{o})$.

15 INA $₫ 101(\mathrm{a})(15)(\mathrm{T})(\mathrm{i}) ; 8$ C.F.R. $\$ \int 214.11(\mathrm{~b})(1)-(\mathrm{b})(4)$. 
problematic as it often leads survivors, government actors, and advocates alike to adopt an excessively restrictive understanding of human trafficking. In law, the designation encompasses two broad sub-categories of trafficking: firstly, 'sex trafficking in which a commercial sex act is induced by force, fraud, or coercion, or in which the person induced to perform such act has not attained 18 years of age'; and secondly, 'the recruitment, harboring, transportation, provision, or obtaining of a person for labor or services through the use of force, fraud, or coercion for the purpose of subjection to involuntary servitude, peonage, debt bondage, or slavery'. ${ }^{16}$ The $\mathrm{T}$ visa offers a host of long- and short-term immigration and public benefits, and, unlike asylum, does not involve an adversarial litigation process for individuals in removal proceedings, making it the clear remedy of choice for immigration practitioners presented with several plausible legal claims.

Carmen would certainly meet the legal definition of a 'victim of a severe form of trafficking in persons', in that she was obtained, harboured, and transported for labour or services; endured force and coercion; and her traffickers intended to subject her to involuntary servitude, defined as 'any scheme, plan, or pattern intended to cause a person to believe that, if the person did not enter into or continue in such condition, that person or another person would suffer serious harm or physical restraint; or the abuse or threatened abuse of the legal process' ${ }^{17}$ However, as we will explore further below, ' $[\mathrm{t}]$ he line between voluntary migrants who participate in smuggling schemes and unwilling trafficking victims — a line that is often murky at best - [is] vigilantly policed'. ${ }^{18}$ Our professional experience suggests that, as a result, US immigration authorities and adjudicators at times do not identify individuals like Carmen as survivors of human trafficking solely because they initially entered into a smuggling arrangement voluntarily. ${ }^{19}$

1622 U.S.C. $\$ 7102(9)(\mathrm{A})-(\mathrm{B})$.

1722 U.S.C. $\$ 7102(6)(A)-(B)$.

18 Chacon, 'Tensions and Tradeoffs', p. 1615.

19 The authors base this assertion on formal documents, including Requests for Evidence and Denial Notices, that their clients have received from US Citizenship and Immigration Services on T visa applications. Such documents have asked clients to clarify why they should be granted protection after 'assuming the risk' of consenting to a smuggling arrangement. For a more detailed discussion, see section 'Obtaining Immigration Relief for Human Trafficking Survivors' below. 
Carmen and similar cases may be eligible for $\mathrm{CP}$ at the moment they are identified by LEAs during border apprehension, as well as multiple forms of permanent immigration relief such as asylum and the $\mathrm{T}$ visa, the latter being much more advantageous in the current political and legal immigration context. Although the US continues to uphold international and domestic legal obligations to protect refugees and asylum seekers,${ }^{20}$ several factors have impeded their ability to obtain legal status in the US. These include a drastic backlog in the immigration court system; a lack of access to legal representation, as there is no right to counsel at the government's expense for migrants fighting deportation in the US; and under-funded and under-staffed legal services organisations. ${ }^{21}$ Moreover, Attorney General Sessions' precedential decision on 18 June 2018, in Matter of $A$ - $B$ - overruled a prior decision, Matter of $A$-R$C-G$-, that had explicitly recognised that survivors of domestic violence can meet the refugee definition and qualify for asylum in the US. The decision in $A$ - $B$-also contained language that threatens to foreclose the claims of asylum seekers fleeing violence by other private actors, such as gangs and organised criminals, thereby making asylum for the majority of Central Americans even more untenable. ${ }^{22}$

20 See, e.g., 8 U.S.C. $\$ 1101(\mathrm{a})(42)$.

21 Human Rights First, In the Balance: Backlogs delay protection in the US asylum and immigration court systems, HRF, 2016, p. i ('620,000 removal and asylum cases are pending, and many asylum-seekers are waiting three to six years for resolution of their claims').

22 Matter of A-B-, 27 I\&N Dec. 247 (A.G. 2018) (case referred by US Attorney General Sessions to himself to determine 'whether, and under what circumstances, being a victim of private criminal activity constitutes a cognizable "particular social group" for purposes of an application for asylum or withholding of removal'; C Dickerson, 'Hundreds of Immigrant Children have been Taken from Parents at U.S. Border', The New York Times, 20 April 2018, retrieved 8 June 2018, https://www.nytimes.com/2018/04/20/us/immigrant-childrenseparation-ice.html; Also, see generally, Kids In Need of Defense (KIND), Death By a Thousand Cuts: The Trump administration's systematic assault on the protection of unaccompanied children, KIND, Washington DC, 2018. 
Furthermore, President Donald Trump has used, and continues to use, polarising and sensational language when referring to undocumented migrants in the US, and has received substantial media attention for doing so. ${ }^{23}$ His administration has launched initiatives to restrict both regular and irregular immigration, and to ramp up immigration enforcement, with critics decrying his policies as racially motivated and responsible for the generation of a 'deportation machine'. ${ }^{24}$ The President has initiated various attempts to impose a travel ban on migrants from predominantly Muslim countries, including a ban and/or stricter security protocol for refugees from such countries. ${ }^{25}$ The US government thus offers permanent legal immigration status and public assistance to refugees based on its international obligations while also expressing hostility towards the very same population and expending substantial resources to restrict future refugee acceptance. ${ }^{26}$

Other relevant categories for cases such as Carmen's are 'illegal alien' and 'criminal alien'-legal classifications that are frequently used in public discourse and reinforce society's perception of 'good' and 'bad' migrants. Under the INA, any person who is not a citizen or national of the US is referred to as an

23 In his Presidential Announcement Speech, Donald Trump described Mexican immigrants as: They're bringing drugs. They're bringing crime. They're rapists.' See: 'Full text: Donald Trump announces a presidential bid', The Washington Post, 16 June 2015, retrieved 8 June 2018, https://www.washingtonpost.com/news/ post-politics/wp/2015/06/16/full-text-donald-trump-announces-apresidential-bid/?utm_term=.b6965a8c9711; H Lee and M Ye, 'Donald Trump's False Comments Connecting Mexican Immigrants and Crime', The Washington Post, 8 July 2015.

24 See, e.g., K Mehrotra, 'Lawyers See Immigration Court as Trump "Deportation Machine", Bloomberg, 4 April 2018, retrieved 18 July 2018, https:// www.bloomberg.com/news/articles/2018-04-04/immigration-court-seen-bylawyers-as-trump-deportation-machine.

25 Executive Order Protecting the United States from Entry of Foreign Terrorists, 27 January 2017, retrieved 20 March 2018, https://www.whitehouse.gov/ presidential-actions/executive-order-protecting-nation-foreign-terrorist-entryunited-states/.

26 USCIS Implementation of Jan. 27 Executive Order, USCIS, retrieved 20 March 2018, https://www.uscis.gov/news/alerts/uscis-implementation-jan-27executive-order. 
'alien'. ${ }^{27}$ 'Illegal alien' and 'criminal alien' are not formally defined in the federal statute, but are frequently used by federal immigration agencies, including USCIS, ICE, and CBP. An 'illegal alien' typically refers to an individual who has entered the US unlawfully or who has overstayed or violated the terms of a visa or temporary immigration status. ${ }^{28}$ Although many human trafficking survivors, like Carmen, may enter the US unlawfully and be initially classified as 'illegal aliens', this does not preclude them from also qualifying for one or multiple forms of immigration relief or legal status. Nevertheless, the use of the term 'illegal alien' has repercussions on the ability of human trafficking survivors to obtain protection, since it evokes images of 'uninvited guests, intruders, trespassers, law breakers' ${ }^{29}$ in the public eye. It 'now also carries undeniable racial overtones and is typically associated with the stereotype of an unskilled Mexican male laborer'. ${ }^{30}$ These public perceptions may influence, whether consciously or not, the behaviour of LEAs, adjudicators, and service agencies responsible for identifying and/or protecting survivors of human trafficking, as discussed further below.

The term 'criminal alien' is routinely used by US immigration agencies in formal documents and policy memoranda to refer to migrants who may be inadmissible or deportable based on criminal conviction or conduct, including repeated immigration violations. ${ }^{31}$ ICE's Criminal Alien Program has been widely criticised for sweeping too broadly, classifying a wide range of vulnerable migrants and non-violent offenders who pose little risk to the general American public as 'criminal aliens'. ${ }^{32}$ Furthermore, immigration offences, making up over half of all federal prosecutions in recent years, have been increasingly criminalised, ${ }^{33}$ thereby reinforcing the stereotype of migrants as 'dangers' to

27 INA $\$ 101(\mathrm{a})(3)$.

28 USCIS Glossary of Terms, 'Legalized Aliens', USCIS, retrieved 20 March 2018, https://www.uscis.gov/tools/glossary/legalized-aliens.

29 Srikantiah, p. 188.

30 Ibid.

31 See: USICE Criminal Alien Program, available at: https://www.ice.gov/criminalalien-program (describing federal initiative 'targeting illegal aliens with criminal records who pose a threat to public safety').

32 See: G Cantor, M Noferi and D E Martinez, Enforcement Overdrive: A comprehensive assessment of ICE's Criminal Alien Program, American Immigration Council, 1 November 2015.

33 Transactional Records Access Clearinghouse Reports, Immigration Now 52 Percent of All Federal Criminal Prosecutions, retrieved 7 January 2018, http://trac.syr.edu/ tracreports/crim/446/. 
US society. As explained by Laila Hlass, 'The past few decades have seen a rapid and staggering convergence of the criminal and immigration regimes, termed "crimmigration." This movement has spawned a mammoth deportation and immigrant incarceration apparatus, with increasingly severe penalties for immigrants who have any contact with law enforcement. ${ }^{34}$

In the next section, we explore how these overlapping categories play out in practice, and how LEAs and immigration adjudicators fail to see many human trafficking survivors as more than 'illegal aliens' or 'criminal aliens' responsible for their own victimisation. The Trump administration's latest measures to forcibly separate children from their family members at the US-Mexico border and criminally prosecute all adults who cross the border illegally will only further exacerbate this complex issue. ${ }^{35}$

\section{Failure to Identify and Protect Human Trafficking Survivors in the US}

LEAs are tasked with implementing the often-opposing mandates of identifying and protecting human trafficking survivors, and of removing 'illegal' and 'criminal aliens'. These conflicting priorities become particularly apparent in cases of migrants who have become victims of human trafficking while being smuggled. Since LEAs like CBP or ICE, and local police forces near the US-Mexico border are often the first agencies to have contact with such individuals, their ability to provide quick and accurate screening can have enormous implications. However, although they present themselves as the frontline defence against human trafficking and publicly pledge to assist survivors, ${ }^{36}$ in practice they are failing woefully in this respect.

34 L Hlass, 'The School to Deportation Pipeline', Georgia State University Law Review, vol. 34, no. 3, 2018, pp. 697-763, p. 705.

35 See, e.g., A Serwer, 'Trumpism, Realized', The Atlantic, 20 June 2018, retrieved 19 July 2018, https://www.theatlantic.com/politics/archive/2018/06/childseparation/563252/; T Kopan, 'New DHS Policy Could Separate Families Caught Crossing the Border Illegally', CNN, 7 May 2018, retrieved 8 June 2018, https:/ /edition.cnn.com/2018/05/07/politics/illegal-immigration-borderprosecutions-families-separated/index.html.

36 US Customs and Border Protection, 'Actions CBP is Taking to Enforce TVPA', retrieved 19 August 2018, https://www.cbp.gov/border-security/humantrafficking. 
We have witnessed this failure first-hand; immigration practitioners in our office and within our networks of local service providers routinely identify individuals as human trafficking survivors for the very first time, although many of them have already been screened by various government agencies and may even have passed through the immigration court system or been ordered expeditiously removed. In cases like that of Carmen, ICE or CBP would often find several survivors during raids of houses where coyotes and/or criminal organisations held them against their will and forced them to work or engage in commercial sex. However, among our clients, none of these victims ever received $\mathrm{CP}$ or any information about their legal right to seek protection under the human trafficking framework. Our clients have reported assisting ICE and CBP in investigations by answering questions for several hours and identifying perpetrators in a photo line-up. Nevertheless, some faced removal proceedings while others were ordered expeditiously removed from the US - a much more limited legal proceeding which provides fewer rights and remedies. Thus, while the LEAs evidently sought to combat the smuggling and trafficking networks at play, they failed either to recognise our clients as human trafficking survivors or to comply with DHS's stated practice of referring them to adequate services and providing information about immigration relief. ${ }^{37}$

A key challenge in identifying human trafficking survivors remains that, although borders are seen as the 'frontlines' of anti-trafficking, agencies tasked with implementing border security and immigration controls are not those best-suited to identify survivors of trafficking - a humanitarian role that often involves complex conceptual challenges even for experts specifically trained in these issues. ${ }^{38}$ It is for similar reasons that individuals who express fear of return to their home countries are referred to USCIS for the Credible Fear Interview (CFI) process, which, although often criticised, has many benefits in theory: an asylum officer specifically trained in this area of law and in dealing with traumatised persons conducts a private interview through an interpreter. ${ }^{39}$

37 Department of Homeland Security, Blue Campaign, Identify a Victim, retrieved 15 August 2018, https://www.dhs.gov/blue-campaign/identify-victim.

${ }^{38}$ M McAdam, 'Who's Who at the Border? A rights-based approach to identifying human trafficking at international borders', Anti-Trafficking Review, issue 2, 2013, p. 36; J Lynch and K Hadjimatheou, 'Challenges and Expectations of Safeguarding and Anti-Trafficking Initiatives at the UK Border', Border Criminologies Blog, 17 July 2017, retrieved 5 June 2018, https://www.law.ox.ac.uk/research-subjectgroups/centre-criminology/centreborder-criminologies/blog/2017/07/ challenges-and.

39 INA $\$ 235(\mathrm{~b})(1)(\mathrm{A}) ; 8$ USC $\$ 1225(\mathrm{~b})(1)(\mathrm{A})(2017)$. 
By contrast, CBP is tasked with 'safeguard[ing] America's borders [and] protecting the public from dangerous people and materials', ${ }^{40}$ while also screening migrants including Unaccompanied Alien Children (UAC) and adults for signs of human trafficking. ${ }^{41}$ This is particularly concerning in the case of UACs, for which CBP uses a two-page questionnaire characterised by the nonprofit Appleseed as inadequate, overly formulaic, and lacking in age-appropriate language. ${ }^{42}$ Moreover, CBP officers at times conduct screening in the presence or close proximity of traffickers, or without interpretation or expertise in assessing trauma-related credibility issues. ${ }^{43}$ The identification and referral of trafficking survivors may benefit from a similar approach to the CFI; i.e. if migrants indicate exploitation, or a fear thereof, CBP officials should refer them to USCIS for an in-depth interview to determine whether it is a case of human trafficking.

An additional challenge in the identification process is that human trafficking survivors often do not self-identify as such or respond to traditional screening questions as expected. ${ }^{44}$ In our experience, they may claim that they were 'unlucky' with their chosen coyote, or that they 'had problems' on the way to the US, but often do not regard themselves as trafficked persons. Significantly, many survivors assume that they do not qualify for legal protection if a coyote or smuggler forces them to work or perform sexual services as payback for the costs of the trip and/or an alleged debt. This belief likely has various complex causes, one of which, based on our interactions with clients, LEA officers, and other practitioners, appears to be the labels and terminology used, including 'severe form of trafficking in persons'. Similarly, when we have brought survivors to the attention of US law enforcement or immigration authorities, like USCIS or ICE, the government actors have frequently failed to recognise the above fact patterns as meeting the relevant legal standards. Our experience

40 US CBP, About CBP, 2016, retrieved 20 March 2018, https://www.cbp.gov/ about.

${ }^{41}$ B Cavendish and M Cortazar, Children at the Border: The screening, protection and repatriation of unaccompanied Mexican minors, Appleseed Network, 2011, retrieved 20 March 2018, http://appleseednetwork.org/wp-content/uploads/2012/05/ Children-At-The-Border1.pdf.

42 Ibid.

43 Ibid., p. 6.

44 Of the recent relevant cases at Ayuda, none of the clients self-identified as a trafficking survivor, despite having been screened by CBP and having had interactions with LEAs. 
suggests that LEAs' screening tools and the officers' trauma-informed assessment skills need improving to ensure identification and protection of trafficking survivors.

\section{Obtaining Immigration Relief for Human Trafficking Survivors}

Whereas LEAs are tasked with the preliminary identification of human trafficking survivors, USCIS is the federal agency that adjudicates certain claims for immigration relief, including applications for $\mathrm{T}$ non-immigrant status. Despite the significant protections granted in human trafficking cases under US federal law, USCIS in practice frequently applies misguided and incorrect legal standards to survivors who voluntarily employed the services of smugglers. When voluntary smuggling arrangements evolve into human trafficking, our own experience and published opinions ${ }^{45}$ confirm the findings of several authors that USCIS regularly conflates smuggling and trafficking, normalises the abuses suffered by migrants during the smuggling process, and blames applicants for their own victimisation. ${ }^{46}$

For example, USCIS recently denied a client's case very similar to Carmen's on the grounds that the applicant was smuggled, not trafficked. ${ }^{47}$ The agency recognised that the person performed domestic services in the form of cooking and cleaning for a cartel, yet argued that she consented to be smuggled and essentially 'assumed the risk' of exploitative situations arising along the journey. USCIS stated that the smugglers did not obtain the applicant's labour through force, fraud, or coercion and found instead that she was 'merely directed' to

45 See, e.g., US Citizenship and Immigration Services, Administrative Appeals Office, Matter of O-F-C-C-, 12 June 2017, retrieved 20 March 2018, https://www.uscis.gov/sites/default/files/err/D12\%20-\%20Application $\% 20$ for $\% 20$ T\%20Nonimmigrant $\% 20$ Status/Decisions_Issued_in_2017 /JUN022017_01D12101.pdf.

46 See, e.g., D Haynes, '(Not) Found Chained to a Bed in a Brothel: Conceptual, legal, and procedural failures to fulfill the promise of the Trafficking Victims Protection Act', Georgetown Immigration Law Journal, vol. 21, 2007, p. 353; Srikantiah, p. 192; A T Gallagher, 2010, p. 277 (noting the complex and timeconsuming process required to successfully determine whether or not a vulnerable migrant is a trafficking victim); Chacon, 'Tensions and Trade-Offs', p. 1612.

47 Decisions issued by USCIS are not made publicly available. These decisions are only sent to the applicant and applicant's attorney. 
cook and clean, discounting the coercive nature of the cartel's threats of death, severe harm, indefinite detention, and forced sex. In another instance, the Administrative Appeals Office (AAO) upheld a denial of a T visa application filed by an individual whose smugglers-turned-traffickers used a threat of physical and psychological coercion to force him to carry bags of unknown contents across the US-Mexico border. In arguing that his labour was not the result of force, fraud, or coercion, the AAO stated that 'the Applicant's own account indicates that the smugglers' abusive actions related directly to the need to avoid detection by law enforcement and to the furtherance of the illegal smuggling operation in which the Applicant had willingly participated'. ${ }^{48}$

In these and other cases, USCIS ignored federal legal precedent that human trafficking can arise during the smuggling process. For example, in U.S. v. SotoHuarto, seven men were sentenced on human trafficking charges, and the 23year sentence received by one of the defendants was the longest sentence received under the TVPA at that point in time. ${ }^{49}$ The defendants had trafficked women from Guatemala, Honduras, and El Salvador who had agreed to pay USD 5,000 to be smuggled into the US. Upon arrival, however, the women had been confined in 'safe houses', where they had been forced to cook, clean, and do housework without pay. Furthermore, USCIS has noted in its own Officer Training Module that 'migrant smuggling, while often undertaken in dangerous or degrading conditions, involves consent. Trafficking victims, on the other hand, have either never consented, or if they initially consented, that consent has been rendered meaningless by the coercive, deceptive, or abusive action of the traffickers. ${ }^{50}$

48 US Citizenship and Immigration Services, Administrative Appeals Office, Matter of O-F-C-C-, 12 June 2017, https://www.uscis.gov/sites/default/files/err/ D 12\%20-\%20Application \%20 for\%20T\%20Nonimmigrant $\% 20$ Status/ Decisions_Issued_in_2017/JUN022017_01D12101.pdf.

49 Federal Bureau of Investigation, Enforcing Civil Rights: Justice served in the case of the Texas sex slaves, FBI, 13 February 2004, retrieved 20 March 2018, https:// archives.fbi.gov/archives/news/stories/2004/february/slave_021304.

50 USCIS, Refugee, Asylum and International Operations Directorate (RAIO), Officer Training: Detecting possible victims of trafficking training module, 2012, p. 10, retrieved 20 March 2018, https://www.uscis.gov/sites/default/files/ USCIS/ About\%20Us / Directorates\%20and\%20Program\%20Offices / RAIO/ Trafficking $\% 20$ LP $\% 20 \% 28$ RAIO $\% 29$.pdf. 
Some USCIS officers fail to recognise and identify the overlaps between what they regard as distinct categories of trafficking victims, i.e. individuals assumed to have no decision-making abilities of their own, and smuggled migrants, whose agency in leaving their country of origin somehow negates their subsequent exploitation. As Dina Francesca Haynes points out, 'The law seems to discourage allowing the victim to discuss her motivations and desire to improve her life, in favor of the story that bears a single-minded focus on the exploitation. ${ }^{51}$ Similarly, Srikantiah argues:

The difficulty is that smuggling and trafficking are hard to distinguish from one another. The typical undocumented economic migrant is propelled by various forms of atmospheric 'push' factors, ranging from dire economic conditions and political instability to strained family circumstances. The difference between the typical economic migrant and the trafficking victim is that the trafficking victim is influenced not only by these factors, but also by the actions of an individual wrongdoer: the trafficker. ${ }^{52}$

\section{Conclusion}

The labels, classifications, and accompanying legal consequences related to the terms 'victim of trafficking', 'refugee', 'illegal alien', and 'smuggled migrant' have significant implications on how society, practitioners, and US immigration authorities view and deal with migrants, as has been illustrated in the context of the Central American refugee crisis. Many of our clients self-identify primarily as migrants displaced by violence and come to our office to inquire about asylum. Frequently, they view forced labour, including sex, at the hands of smugglers as an unfortunate occurrence during their journey, but do not regard victimisation by smugglers as a significant part of their narrative.

However, Central American migrants seeking legal protection in the US may fit into several categories at once, and the responses of US immigration authorities to these competing classifications vary depending on public rhetoric and political priorities. The negative discourse surrounding 'illegal

\footnotetext{
51 Haynes, p. 353.

52 Srikantiah, p. 192.
} 
immigration' may lead human trafficking survivors to mask the causes of their migration and the way they entered the US. As a consequence, they may not disclose their victimisation at the hands of smugglers. This further diminishes their chances to be identified by either LEAs or service providers as survivors of human trafficking and to be granted T non-immigrant status. Moreover, when survivors do come forward and highlight their exploitation, LEAs and US immigration adjudicators often react with suspicion and doubt, as if an individual's decision to leave their country of origin and make use of a smuggler to escape dire circumstances negates their victimhood.

Due in large part to the US government's heightened focus on border security and the criminalisation of many forms of migration, the plight of human trafficking survivors reflects a much broader problem: the contradictory nature of border control and anti-trafficking policies in the US. The US is idealised as a 'nation of immigrants' and prides itself for its protection of vulnerable and victimised groups. However, the focus on immigration enforcement and border security-currently intensified under the Trump administration-prevents these ideals from being realised in practice. Without a change, violent organised criminals, including smugglers who traffic desperate people in desperate circumstances, will continue to operate with impunity, and their victims will continue to be denied justice, remaining in the shadows at the boundaries of the legal categories that could change, and potentially even save, their lives.

Katherine Soltis is an Immigration Staff Attorney at Ayuda, a non-profit organisation that serves and advocates for low-income immigrants through direct legal, social, and language services, training, and outreach in the Washington, DC metropolitan region. She graduated cum laude from Harvard Law School and summa cum laude from Duke University, where she obtained her Bachelor's Degree in International Comparative Studies and Political Science. She began her legal career in 2015 as an Equal Justice Works Fellow, sponsored by Verizon Wireless and DLA Piper, at Ayuda, during which time she provided direct representation to human trafficking survivors and coordinated outreach and training on issues related to human trafficking. She is a member of the Northern Virginia Human Trafficking Task Force and the Montgomery County Human Trafficking Task Force. Email: katies@ayuda.com.

Rebecca Walters is a Supervising Immigration Attorney at Ayuda, a nonprofit organisation that serves and advocates for low-income immigrants through direct legal, social, and language services, training, and outreach in the Washington, DC metropolitan region. She graduated summa cum laude from 
American University Washington College of Law and obtained her Bachelor's Degree in Foreign Affairs from the University of Virginia. She began her legal career as a Skadden Fellow at Ayuda's Virginia office. She has over eight years of experience representing both child and adult survivors of human trafficking in a variety of immigration matters for survivors facing deportation. She currently serves as a Steering Committee Member for Freedom Network USA, a national alliance of advocates advancing a human rights-based approach to human trafficking. Email: rebecca@ayuda.com. 


\title{
'Circuit Children': The experiences and perspectives of children engaged in migrant smuggling facilitation on the US-Mexico border
}

\author{
Gabriella Sanchez
}

\section{Abstract}

In Mexican child protection circles the term 'circuit children' has been used to designate people under the age of 18 who cross the US-Mexico border irregularly and cyclically for the purpose of smuggling drugs or irregular migrants. Young people of the border region have historically been involved in these markets. Yet their activities have become more visible in recent years in the context of increased border militarisation, and immigration and crime controls implemented by both the US and Mexican governments. Depicted in official and media discourses as forced recruits of local organised crime gangs, circuit children have increasingly been at the centre of initiatives that seek to identify and treat them as victims of trafficking. These efforts often rely on portrayals that frame them as gullible and defenceless, and their families and communities as inherently dysfunctional, dangerous and crime-prone. The structural and geopolitical conditions related to the children's participation in smuggling, however, remain unchallenged. Most troublingly, trafficking discourses tend to silence the perspectives of circuit children themselves. This paper, based on interviews and participant observation, shows how circuit children, rather than seeing themselves as victims, articulate legitimate, important claims concerning their engagement in illicit markets, reflective of the ways they navigate the complex economic, socio-political and migratory contexts of the US-Mexico border.

Keywords: migrant smuggling, circuit children, US-Mexico Border, human trafficking

Please cite this article as: G Sanchez, "Circuit Children": The experiences and perspectives of children engaged in migrant smuggling facilitation on the USMexico border', Anti-Trafficking Review, issue 11, 2018, pp. 103-119, www.antitraffickingreview.org

This is an open-access article distributed under the terms of the Creative Commons Attribution License (CC-BY). Under the CC-BY license, the public is free to share, adapt, and make commercial use of the work. Users must always give proper attribution to the authors and the Anti-Trafficking Review. 


\section{Introduction}

Migrant smugglers — typically portrayed as foreign criminals who have hijacked borders worldwide_-are practically intrinsic to contemporary discourses on migration management and control. Smugglers are frequently depicted in media, academic and political narratives as adult men of colour from the global south, ${ }^{1}$ who as members of organised crime follow a complex business model to prey on the desperation and vulnerability of migrants. ${ }^{2}$

Despite the ubiquity of these messages, empirical research on the people behind migrants' journeys is scant. Researchers have dedicated significant time to study migrants' mobility experiences, which are often characterised by conflict and risk. There is, undoubtedly, abundant evidence of the abuses endured by migrants at the hands of smugglers. Smuggling is inherently perilous for it involves clandestine, criminalised activities. It concerns people facing different levels and kinds of vulnerability. ${ }^{3}$ None of smuggling's actors can effectively reach out to authorities for help when needed, and the agreements behind journeys cannot be effectively enforced.

Still, there is a growing body of research focusing on the experiences of smuggling facilitators themselves. Opposing a state-centric model dominated by security discourses, this work has sought to situate the facilitation of migration within traditional, indigenous, and community-based strategies of mobility. In other words, it has shown how ordinary mobility efforts are increasingly 'manufactured' as migrant smuggling within contemporary

1 See, for example: M Politzer and E Kassie, 'Niger: Smuggler's paradise', Huffington Post, 21 December 2016, retrieved 5 September 2018, https:// highline.huffingtonpost.com/articles/en/the-21st-century-gold-rush-refugees/\#/ niger; N Sobecki, 'My Smuggler, My Savior', Foreign Policy, 4 October 2017, http:// europeslamsitsgates.foreignpolicy.com/my-smuggler-my-savior-portraits-nigerafrica-europe-EU-smuggling-migration; J Holman, 'Portrait of a People Smuggler', Al Jazeera, 25 January 2016, https://www.aljazeera.com/indepth/features/2015/ 12/portrait-people-smuggler-151231125324569.html.

2 Europol-INTERPOL, Migrant Smuggling Networks in the EU: Joint Europol-INTERPOL report, Brussels, 2016.

3 W Vogt, 'Stuck in the Middle with You: The intimate labours of mobility and smuggling along Mexico's migrant route', Geopolitics, vol. 21, issue 2, 2016, pp. 366386; J Hagan, Migration Miracle: Faith, hope and meaning on the undocumented journey, Harvard University Press, Massachusetts, 2012. 
migration regimes. ${ }^{4}$ This research has also challenged the claim that migrant smuggling is generally controlled by transnationally organised crime syndicates, arguing that such narratives, at a minimum, are incomplete. Scholars have shown empirically that ordinary people-from indigenous men and women to residents along migrant trails, and from current and former migrants to elderly and at-risk adults_ - play different roles in the facilitation of migrants' journeys, operating independently and/or within personal networks, and seeking to supplement limited incomes, lacking criminal intentions or ties. ${ }^{5}$

Researchers have also identified children ${ }^{6}$ as part of smuggling processes. Children pilot the boats in which migrants travel, serve as guides and decoys, and often recruit additional children to smuggle other migrants. ${ }^{7}$ Some perform these tasks in exchange for wages or in-kind compensation, while others do so to work off their own smuggling fees as part of personal mobility strategies. ${ }^{8}$ Children's experiences in smuggling are also different from those of their adult counterparts; they face specific risks, as they often lack the social or financial capital and/or standing of adults, and their physical and emotional wellbeing

4 J Brachet, 'Manufacturing Smugglers: From Irregular to Clandestine Mobility in the Sahara', Annals of the American Academy of Political and Social Science, vol. 676, issue 1, 2018, pp. 16-35; V Stone-Cadena and S Alvarez-Velasco, 'Historicizing Mobility: Coyoterismo in the Indigenous Ecuadorian migration industry', Annals of the American Academy of Political and Social Science, vol. 676, issue 1, 2018, pp. 194-211.

5 S Zhang, Chinese Human Smuggling Organizations: Families, social networks and cultural imperatives, Stanford University Press, 2008; S Izcara Palacios, 'Coyotaje and drugs: Two different businesses', Bulletin of Latin American Research, vol. 34, issue 3, 2015, pp. 324-339; G Sanchez and S Zhang, 'Rumors, Encounters, Collaborations, and Survival: The migrant smuggling-drug trafficking nexus in the U.S. Southwest', Annals of the American Academy of Political and Social Science, vol. 676, issue 1, 2018, pp. 135-151; G Sanchez, Human Smuggling and Border Crossings, Routledge, London, 2016.

6 The term 'children' in this paper refers to anyone below the age of 18.

7 See: W Palmer and A Missbach, 'Trafficking within Migrant Smuggling Operations: Are underage transporters "victims" or "perpetrators"?', Asian and Pacific Migration Journal, vol. 26, issue 3, 2017, pp. 287-307; G Sanchez, B Navarrete, F Loera and C Zavala, Neither Criminals nor Illegals: children and adolescents in the migrant smuggling market on the US-Mexico Border, Derechos Humanos Integrales en Acci n (DHIA) and University of Texas El Paso, 2017, available at http://hdl.handle.net/1814/ 50984.

8 IOM, Egyptian Unaccompanied Migrant Children: A case study on irregular migration, IOM Egypt Office, 2017. 
can be compromised more easily. ${ }^{9}$ As a result, they are an easier target of exploitation and abuse. ${ }^{10}$ Yet our knowledge of their experiences in smuggling remains limited as well.

Relying on ethnographic work conducted with children who participate in smuggling, this paper's objective is to bring into the conversation their perspectives and experiences. Known in Mexican child protection circles as 'circuit children' they are people under the age of 18 who cross the US-Mexico border irregularly and cyclically for the purpose of smuggling drugs or irregular migrants.

Young people have historically been involved in these markets along the USMexico border. Yet their activities have become more visible in recent years in the context of increased border militarisation, and immigration and crime controls implemented by both the US and Mexican governments. Depicted in official and media discourses as forced recruits of local organised crime gangs, ${ }^{11}$ circuit children have increasingly been at the centre of initiatives identifying and treating them as victims of trafficking. These efforts often rely on portrayals that frame them as gullible and defenceless, and their families and communities as inherently dysfunctional, dangerous and crime-prone. The structural and geopolitical dynamics they face, however, remain unchallenged. Most troublingly, the focus on trafficking has silenced the perspectives of the children themselves, who far from seeing themselves as victims, articulate legitimate, important claims concerning their participation in illicit markets which reflect the ways they navigate the complex economic, socio-political and migratory contexts of the border.

9 L Heidbrink, Migrant Youth, Transnational Families and the State: Care and contested interests, University of Pennsylvania, Philadelphia, 2014.

10 UNICEF, IOM, UNHCR, Eurostat and OECD, A Call to Action: Protecting children on the move starts with better data, UNICEF, New York, 2018.

11 See: L Melesio and J Holman, 'Mexico cartels recruit children to smuggle people to US', Al Jaz̧eera, 30 October 2017, https://www.aljazeera.com/news/2017/10/ mexico-cartels-recruit-children-smuggle-people-171030103553245.html; H Martinez-Prado, 'Reclutan a ninos como polleritos', El Heraldo de Mexico, 14 August 2018, https://heraldodemexico.com.mx/estados/reclutan-a-ninos-comopolleritos/. 


\section{What is Child Trafficking?}

Some scholars and child protection advocates have begun to label children's participation in migrant smuggling as a form of trafficking in persons, ${ }^{12}$ defined in the UN Trafficking Protocol as:

'the recruitment, transportation, transfer, harbouring or receipt of persons, by means of the threat or use of force or other forms of coercion, of abduction, of fraud, of deception, of the abuse of power or of a position of vulnerability or of the giving or receiving of payments or benefits to achieve the consent of a person having control over another person, for the purpose of exploitation. ${ }^{13}$

The Protocol further states that, in the specific case of children, consent is irrelevant and that 'the recruitment, transportation, transfer, harbouring or receipt of a child for the purpose of exploitation shall be considered "trafficking in persons" even if this does not involve any of the means [stated above]. ${ }^{14}$

Moreover, 'the use, procuring or offering of a child for illicit activities ...' is also defined as a worst form of child labour under ILO Convention 182 and regarded as exploitative. ${ }^{15}$ In other words, according to international law, children who are recruited into smuggling, even if willingly so, are to be considered victims of trafficking.

It is imperative to provide protection to children who have fallen prey to criminal undertakings. Yet it is also fundamental to analyse the structural and ideological contexts in which such activities take place-and the justifications provided by various actors to counter them. ${ }^{16}$ In this case, the very call to designate the experiences of children in smuggling as a form of trafficking in

12 See, for example, Palmer and Missbach, 2017.

13 UN General Assembly, Protocol to Prevent, Suppress and Punish Trafficking in Persons, Especially Women and Children, Supplementing the United Nations Convention against Transnational Organized Crime, 15 November 2000, (Trafficking Protocol), Art. 3 (a). 14 Ibid., Art. 3 (c).

15 International Labour Organization, Convention concerning the Probibition and Immediate Action for the Elimination of the Worst Forms of Child Labour, 17 June 1999, Art. 3 (c).

16 A Wilson, Intimate Economies of Bangkok: Tomboys, tycoons and Avon ladies in the Global City, University of California Press, Sacramento, 2004. 
persons implies the acceptance of the state-centric notion that the facilitation of informal, clandestine mobility strategies inherently constitutes a crime. Furthermore, it relies on the argument that smuggling is the exclusive domain of organised crime - a claim that has been empirically brought into question. Most troublingly, both assertions risk leaving untouched the structural and geopolitical challenges that children engaged in smuggling encounter.

\section{The US-Mexico Border, Children and the Mexican Migrant Smuggling Market}

For generations, communities along the US-Mexico border have been construed as abject and dangerous places where crime and vice abound, ${ }^{17}$ and have endured efforts from their respective governments to 'secure' them. ${ }^{18} \mathrm{In}$ the US, strategies have involved the deployment of law enforcement and military forces, or the construction of walls and fences. ${ }^{19}$ Mexico has also relied on troops deployed to its border cities and towns as part of a national security strategy against crime. The securitisation of the border has all along relied on the hyper-surveillance of historically marginalised and often isolated border communities, ${ }^{20}$ coincidentally situated in privileged locations for contraband activities - a common if highly criminalised form of informal labour on the borderlands. ${ }^{21}$

17 R Dorantes, 'Homeland Secretary Nielsen said border is becoming more dangerous', KSWT 13, 18 April 2018, retrieved 8 September 2018, https://www.kyma.com/ news/homeland-secretary-nielsen-said-border-is-becoming-more-dangerous / 731515619; J A DelReal, 'Donald Trump announces presidential bid', Washington Post, 16 June 2015, https://www.washingtonpost.com/news/post-politics/wp/ 2015/06/16/donald-trump-to-announce-his-presidential-plans-today/ ?utm_term $=.54 \mathrm{a} 6527737 \mathrm{ea}$.

18 See, for example: US Department of Homeland Security (US DHS), 'We Must Secure the Border and Build the Wall to Make America Safe Again', Press release, 15 February 2018, https://www.dhs.gov/news/2018/02/15/we-must-secure-borderand-build-wall-make-america-safe-again.

19 P Andreas, Border Games: Policing the US-Mexico divide, Cornell University Press, New York, 2009; J Nevins, Operation Gatekeeper and Beyond: The war on "illegals" and the remaking of the US-Mexico Boundary, Routledge, New York, 2010.

20 G Núñez and J Heyman, 'Entrapment Processes and Immigrant Communities in a Time of Heightened Border Vigilance', Human Organization, vol. 66, no. 4, 2007, pp. 354-365.

21 S Guerra, 'La Chota y los Mafiosos: Mexican American casualties of the border drug war', Latino Studies, vol. 13, issue 2, 2015, pp. 227-244; Sanchez, 2016. 
Ciudad Juárez, located on the Mexican side of the border, is one of these communities. It has been repeatedly labelled as 'the most violent city in the world', partly due to drug-related crime and the state's responses thereto, and patterns of gender-based violence that have led to high rates of femicide, among other crimes. ${ }^{22}$ None of these problems, however, have emerged in a vacuum. Following US Prohibition, and as a result of its immediate proximity to the US, Juárez became a destination for Americans traveling to Mexico to obtain illicit substances whose consumption had been banned in the US. ${ }^{23}$ The city's dependency on the US' consumption of goods and services translated into an economy of limited employment and educational opportunities for its own residents. While the arrival of manufacturing plants or maquiladoras in the 1970s brought thousands of jobs into the city, urbanisation levels remained low. ${ }^{24}$ Incoming residents, including large numbers of women attracted by better paying employment opportunities in the maquila, often settled in remote areas of the city, where access to basic services, including water, sewage, public transportation, emergency care or law enforcement was scant. ${ }^{25}$ Such residential conditions have largely remained unchanged, with most factory employees still living in the periphery of the city, often under precarious circumstances. Sidelined by the urban economy, the residents of Ju rez's periphery often rely on informal labour as a strategy to supplement limited earnings. ${ }^{26}$ Further, the proximity to the border has led many to become involved in illicit and/or

22 See, for example: S Quinones, 'Once the world's most dangerous city, Juarez returns to life', National Geographic Magazine, June 2016; K Romero, 'The dangerous ghost town even POLICE don't dare to enter: Welcome to Mexico's murder valley', The Express, 1 January 2016, retrieved 14 September 2018, https://www.express.co.uk/ travel/articles/630733/the-dangerous-ghost-town-mexico-death-valley-juarezpictures; M von Rohr, 'The most violent city on earth: Ciudad Juarez takes on the drug cartels, Spiegel Online, 23 September 2009, http:/ /www.spiegel.de/international/ world/the-most-violent-city-on-earth-ciudad-juarez-takes-on-the-drug-cartels-a650553.html.

23 Many historians claim the current landscape of drug trafficking in Mexico, and of Juárez in particular can be traced to the US Prohibition, when the city emerged as the main supplier of alcohol for US consumption. The mechanisms to supply and smuggle alcohol were eventually adapted to other illicit drugs. See: H Campbell, Drug War Zone: Frontline dispatches from the street of El Paso and Juarez, University of Texas Press, Austin, 2009.

24 GC Valdez-Gardea, 'Current Trends in Mexican Migration', Journal of the Southwest, vol. 51, no. 4, 2009, pp. 563-583.

25 Núñez and Heyman.

26 Guerra. 
criminalised activities for income generating purposes, ${ }^{27}$ including migrant smuggling.

\section{Methods}

This paper documents the experiences of children from the periphery of Ciudad Juárez who were identified by Mexican authorities as circuit children as a result of their involvement in the smuggling of migrants into the US city of El Paso, Texas. It is based on data collected between 2015 and 2018, and involves 18 interviews with children aged 14 to 17 as well as ethnographic observations carried out through personal interactions with the children, their friends, family members and a team of social workers who assisted them in Ciudad Juárez. These interactions involved attending parties, community gatherings, visits to museums and parks, focus groups and debriefing exercises intended for the children to reflect on their border crossing experiences. Sixteen of the respondents were boys; two were girls. Sixteen interviews took place in person, and two over the phone. All interactions took place in Spanish.

The children were recruited for interviewing following their referral to a local non-profit organisation, which administered a state-funded programme based in Ciudad Juárez targeting circuit children. The programme aimed to reduce the likelihood of children to engage in risk-prone behaviour-including migrant smuggling - through the provision of educational, employment, recreational and therapeutic services. The 18 children were selected upon recommendations from the social workers who worked with them, based on their level of participation in the programme. Parental and/or guardian consent was obtained prior to any research-focused interactions with the children, who also provided their own consent. No deception was used.

The children were informed that their responses would be used to better understand the lives of young people like themselves living on the border, and to devise potential ways to improve their quality of life. In line with the research strategies used by Zhang, Sanchez and Achilli ${ }^{28}$ in their work with adults involved in migrant smuggling, the children were not asked about

27 Campbell; Sanchez.

28 Sanchez and Zhang. See also: L Achilli, 'The Good Smuggler: The ethics and morals of human smuggling among Syrians', The Annals of the American Academy of Political and Social Science, vol. 676, issue 1, 2018, pp. 77-96. 
smuggling in and of itself. Instead, the questions focused on their social lives as border residents, and on the implications that their experiences crossing the border had had on themselves and their families. The children were not asked questions that would incriminate or connect them to specific people or practices. Any data that could trace statements to specific children, their families or their places of residence has been removed to further preserve the respondents' anonymity.

\section{Smuggling as an Economic Activity}

The children perceived the facilitation of border crossings as a viable and legitimate occupational activity. Helping migrants enter the US allowed the children to profit from their privileged knowledge of local conditions. A 15year-old described how he used his knowledge of a hill close to his home to attempt reaching El Paso:

'Well, of course I know the hill, we played there! I live like three blocks away from it. I knew where the good hiding places were. I just had to do what I always did. Go up the hill, hide, as us kids do! The bad thing was that the day my friends and I tried to cross it was really hot. I didn't think about that. And after two hours of walking I was like no way, I can't do this. And we just sat by a little shrine and waited. Immigration came by really soon. Another time a lady came by, I was by the dam gates. She asked me if I knew how to get across and I said yes, that I could guide her, but la migra ${ }^{29}$ caught us before we were able to cross.'

While media often describe children engaged in smuggling as passive or manipulated subjects at the mercy of criminal groups, the boys and girls in this study conceptualised their involvement in criminalised activities as the result of conscious and personal attempts to reduce the financial and emotional precarity faced by themselves and their families. A 14-year-old narrated how he took the job of a lookout after he dropped out of school at age 11:

'I had stopped going to school, I used to get bored there. And so my friend invited me to be a lookout for the times when the older guys crossed people. I had nothing else to do, and my friend and I would

29 US immigration agents. 
just go, sit by the place where we usually played and help out. I thought, at least doing this I am making some money, right? So I stayed and worked with them for a while.'

These perceptions were at times shared by the children's relatives, who may also benefit from the earnings. The older sister of a teenage boy who worked as a smuggling guide described her brother's rationale to join the market:

'My parents died and I was already married so I brought my little brother and sister to live with us. But my brother realised pretty quickly that we were struggling [financially]; he was not dumb. My husband did not earn much and I could not go get a job because there was nobody who could help me watch my children. One day my brother came home and gave me money and said, "here, so that you can buy us food." I got scared because he was only 13 and I wondered, where [did he get] all this money from? And so I asked him, and he wouldn't tell me. "What do you care", he said, "I am just tired of seeing how much you guys struggle. Just take it." I didn't like [that he was involved in smuggling], but I was like, what else is there for him to do? [My husband and I] would sit down with him, tell him we wanted him to go back to school. But he also knew we couldn't afford that, and so he would just go work with this other boy his age.'

None of the children described their entrance into smuggling as the result of pressure, coercion, or recruitment from organised crime, as press and official reports often claim. Instead, most were invited to join a job (un jale) by trusted people like friends or family members, or by older peers who were already participating in the activities. A teenage boy who worked as a guide explained:

'I was with two of my friends, just there doing nothing, and this guy we know came by and said he was looking for three people to cross people and we said, sure why not? He asked us to come by later on and we did and that was how we got into it.'

The children benefitted financially from their activities, although their compensation varied greatly and assignments were infrequent. ${ }^{30}$ Moreover,

30 Compensation promises or estimates are not a reliable indicator of smuggling earnings. While on occasion, successful outcomes following an act of smuggling may generate several hundred dollars for a child, income is never guaranteed, constant nor fixed, and many times promises of payment go unfulfilled. 
income generation was only one of several aspects that they considered important or relevant to their experience. For example, working was also seen as a path towards social recognition and acceptance. On occasion, their earnings allowed them to assume roles otherwise restricted to adults — and in particular, to men. This is of special relevance since most children involved in the market are boys, and many come from single-parent households. A teenage boy who worked as a guide explained how, by the age of 12 , his involvement in smuggling had made him his family's main provider-a role he had understood as traditionally reserved to adult men. Working allowed him to fulfil 'gendered social hierarchies and expectations, but also [to] reproduce and reinforce them': ${ }^{31}$

'We were able to buy pizza for everyone. You know, the one with ham and pineapple-that was my favourite. I was only 12 but I knew [then] what it meant to be able to buy that by myself, for my little siblings. Se siente bonito [it feels nice] to be able to buy shoes and clothes for everyone, to tell my mom not to worry, that I can take care of things. I also realised that my little siblings looked up to me as a father; they would call me papá. And my boss liked me because I was a good worker. That also made me feel good, that I could be of service, that what I did meant something.'

During interviews, several children noted that they spent their earnings on new clothes, cell phones and eating out. Many others proudly spoke about how they envisioned their employment as a way to move out of poverty. Some said that they shared their earnings with their mothers, or bought presents for their younger siblings. In sum, all children indicated that the economic activities allowed them to pursue personal, social and economic projects that symbolically raised their status.

\section{Smuggling as Emotional Labour}

While depicted in the media as inherently criminal and violent communities, the interviewed children described their working-class neighbourhoods in the periphery of Ciudad Juárez as the places where

31 J Miller and K Carbone-Lopez, 'Beyond "Doing Gender": Incorporating race, class, place and life transitions into feminist drug research', Substance Use and Misuse, vol. 50, no. 6, 2015, pp. 693-707. 
they felt welcome and safe. Many preferred to stay in their communities rather than going into other parts of the city. In fact, several reported that they knew few other places in Juárez. Some described how at times, when going to different neighbourhoods, or public spaces like malls and markets, they would be followed by security guards, or even be asked to leave by staff or other adults.

The children enjoyed describing the ways in which they spent afternoons together among friends, visiting relatives or meeting people. The neighbourhood was an important place for recreation and community building, and most importantly a safe space. A 17 -year-old girl who had worked as a lookout noted when shown pictures of her neighbourhood:

'When I see pictures of my colonia [neighbourhood] it feels nice. I think, see? 'That's where I'm from. [Pointing at the picture] There is my aunt's house, my mom's house, the street where I play with my friends. There are poor people, and yes, there are also bad people. But it is my neighbourhood, you see. We get together, party together, go to school together. I like my neighbourhood and I miss it when I'm gone. I really do.'

This attachment to their own families and community also led children to empathise with the migrants whose journeys they facilitated. A female teenager who had worked as a decoy explained:

'It is very sad that you can't be with your family because of what happens at the border. I always felt bad about the people we crossed. Why? Because we are poor but we have always been together. If it is not my mom, the one who is caring for my boy and my little siblings (...) is me, so I understand that it is only natural that people want to be with their families. I believe there is nothing wrong with [migrants] wanting that too, and if we can help them, even better. It felt good dropping people off and watching them reunite with their families; that always made me cry. But I was also worried of what could happen to my family if I got caught, and so I stopped [working as a decoy]; I didn't want to be separated from them.'

Further, empathy with migrants, underpinned by family values and traditional role expectations, led one boy to express a preference for transporting female migrants, whom he perceived as facing specific, gendered vulnerabilities. Having worked as a driver from the age of 12 , he explained: 
'I always looked for the women at the safe houses. Don't ask me why, I just did. I guess they reminded me of my mom and my sisters. I would walk in, find them, wake them up if they were asleep and tell them, "wake up, I am here to drive you, let's go, you don't have to stay here." I had heard really bad stories of what happens to women when they cross and I didn't want anything to happen to them. And then we would drive and they would be all quiet but I will then try to put them at ease by telling jokes and they would ask me how old I was and when I told them they would laugh [because I was so young] and that would kind of break the ice. I wanted them to feel good, that they could trust me. Sometimes we would exchange numbers and they would text me when they arrived at their destination. It felt nice to be part of what they went through, that I could help.'

Similar to the girl who worked as a decoy, this teenager's testimony stands as an example of the emotional support the circuit children provided through humour, casual conversations, and attempts to generate a sense of normalcy for the migrants whom they transported.

\section{Risks and Challenges Faced by Children Engaged in Smuggling}

The children's testimonies were also packed with reminders that their participation in smuggling was far from safe. There are serious physical risks associated with an activity often performed in inaccessible and rugged corridors. It was common for the children to report injuries involving the handling of tools or equipment, or experiences of bone dislocations, fractures or bites from local fauna. A 16-year-old boy described how he had almost drowned while crossing a canal:

'One night we were working, we were not expecting it but the dam's gate was open and the current dragged me. I could not feel the bottom of the canal. The good thing is that we were working [in pairs], because my partner grabbed the collar of my shirt and pulled me out. If it hadn't been for him I think I would have died.' 
Moreover, and contrary to reports from the media and state officials, the children's testimonies indicated that the acts of violence they endured were not only related to organised crime groups. ${ }^{32}$ Instead, they often reported experiencing emotional or physical abuse at the hands of peers or family members whom they worked with. One child explained how, after indicating that he no longer wanted to engage in smuggling, he was tied and blindfolded by an older boy who then also unleashed a fighting dog on him. A few children felt pressured to remain in smuggling due to their families' financial expectations and legitimate needs. One boy opted to apply for asylum in the US after his father refused to allow him to quit his job as a guide. Some children also entered into conflict with other groups or criminal actors through their work, such as by using an off-limits route designated for drug trafficking. This, at times, exposed them to threats or intimidation. One child reported having to move temporarily to another state for this reason, for example.

While violence from friends, family members or criminal actors posed serious risks, interactions with law enforcement officers-especially those ascribed to the US Border Patrol-were consistently described as the most feared and dangerous. The children reported having endured verbal abuse, assault and beatings by law enforcement, and highlighted at least two cases where children like themselves were killed by Border Patrol agents. ${ }^{33}$ One of the respondents

32 This does not intend to suggest that violence at the hands of criminal groups is minimal or inexistent. Children reported having witnessed or heard of instances in which other circuit children (often migrant children travelling unaccompanied or from cities other than Juárez) had been severely beaten, shot or even killed for not following instructions from the adults who employed them. In this sample, threats of violence, or apprehension experiences proved enough of a deterrent to keep most children from re-attempting a border crossing.

33 The deaths of Sergio Hernandez Guereca and Jose Antonio Elena Rodriguez have generated condemnation over the US Border Patrol treatment of and interactions with young people and children of the US Mexico Border. See: J Burnett and M Kennedy, 'Supreme Court Sends Cross-Border shooting case back to lower court', NPR News, 26 June 2017, retrieved 12 August 2018, https:/ /www.npr.org/sections/ thetwo-way/2017/06/26/533968647/supreme-court-sends-cross-border-shootingcase-back-to-lower-court?t $=1536241861264$. At least six children have been reportedly murdered by Border Patrol agents on duty. See: S Macaraeg, 'Fatal Encounters: 97 deaths point to pattern of border agent violence across America', The Guardian, 2 May 2018, https://www.theguardian.com/us-news/2018/may/ 02/ fatal-encounters-97-deaths-point-to-pattern-of-border-agent-violence-acrossamerica. 
described how, following his apprehension, a male agent had attempted to pull by force an earring he was wearing: 'I got mad, and I told him, just pull it, whore, and I will sue you. He left me alone after that.'

By law, children found to be involved in smuggling activities do not face criminal charges due to their age. Yet, they are invariably subjected to questioning by US authorities, with child advocates having repeatedly expressed concerns over the ways US Border Patrol agents carry out interrogations in public, in a language other than the child's, and without the presence of legal counsel or parental notification. ${ }^{34}$ Further, the tense interactions between teenagers and immigration agents sometimes lead to self-incriminatory statements, as this 17-year-old demonstrated:

'[The Immigration agent] asked me how many times I had [crossed migrants], and I said, what do you care, idiot. Twenty, thirty, forty, I don't know. And the agent wrote it down as if that was true. I was mad, I was angry. I had gotten caught. He wrote it all down and then they let me go. And then when [immigration] caught me again and sent me to court [the attorney for the state] said I had [admitted to the crime] to [USBP agents]. [Laughs]. Damn it. What was I supposed to say? I didn't know.'

\section{Analysis and Conclusion}

This paper expresses concerns about the state-centric narratives often applied in discourses on children's engagement in smuggling along the US-Mexico border, including its increasing designation as a form of human trafficking or as under the monopoly of criminal syndicates. Monolithically depicting smuggling as controlled by organised crime-and children as forcefully participating in such activities as victims of trafficking-is incomplete at best.

These perspectives are not only indicative of a lack of knowledge of smuggling dynamics; most troublingly, they fail to incorporate the children's views of their personal life projects within the structural limitations they face. In other words, such simplistic narratives exclude their voices from discussions of the conditions that lead to their marginalisation as working class youth on the US-Mexico border.

34 See: G Sanchez, B Navarrete, F Loera and C Zavala; and B Cavendish and M Cortazar, Children at the Border: The screening, protection and repatriation of unaccompanied Mexican minors, Appleseed Foundation, Washington DC, 2011. 
Research on smuggling is scant, and studies documenting the experiences of children in this context are even less common. In fact, most engagements with children's smuggling activities have been journalistic in nature, and have often referred to them as coyotitos or polleritos-diminutives of derogatory terms used colloquially in reference to adult migrant smugglers. Such coverage regularly replicates and reinforces the above state-centric narrative describing the children as desperate, submissive drug addicts, forcibly recruited by organised criminals into what is labelled as a lucrative migrant smuggling trade. ${ }^{35}$ Many law enforcement agencies, politicians and scholars on the border have relied on these increasingly common media reports and language to claim that the circuit children phenomenon has grown, and that this growth is largely due to a lack of punitive laws. ${ }^{36}$

The data presented here shows that the children perceive their engagement in smuggling as a legitimate strategy to overcome the economic, socio-political and migratory barriers faced by themselves and their communities. Furthermore, their experiences point, as Vogt argues, to 'the ways in which smuggling becomes a point of closeness and intimate exchange ${ }^{37}$ among children, the people they work with, the migrants they transport or guide, and the authorities who apprehend them.

To bring these perspectives into the discussion does not imply minimising the risks children face, including dangerous work conditions, violent interactions with peers and family members, or intimidation, criminalisation and even death at the hands of law enforcement agents. Instead, it helps to juxtapose the ways children see their experiences with the narratives ascribed to them, and in so doing allows gaining new insights into young people's lives.

35 L Melesio and J Holman; H Martinez-Prado.

36 O Hernandez-Hernandez, 'Menores de Circuito en Tamaulipas', Crónica, 17 February 2018, retrieved 14 August 2018, http://www.cronica.com.mx/notas/2018/ 1065596.html; A Guerrero, 'Informe alerta del aumento de polleritos, niños que usa el crimen para traficar migrantes', Sin Embargo, 28 April 2017, http:// www.sinembargo.mx/28-04-2017/3203832.

37 Vogt. 
The children's testimonies suggested that some risks to their lives and wellbeing were the result of external, top-down, state-centric approaches to border control. Intimidation on the part of US Border Patrol, through its reliance on aggressive questioning tactics, led frustrated and scared young people into providing self-incriminatory statements that were later used against them in courts. Fear of being caught and arrested increased the propensity to engage in risky physical activities that could lead to serious injuries. The lack of mechanisms allowing children to migrate safely and with dignity contributed to them devising their own mobility strategies.

It is pivotal to remember the hypervisibility of the US-Mexico border in migration and security discourses, and how these have translated into real, specific manifestations of securitisation, marginalisation and stigmatisation impacting its communities. Alongside simplistic explanations of complex social practices like smuggling, the unrestricted, uncritical use of terms in policy, but also in academic discourses that belittle border crossing practices and their actors through terms like wetback, coyotito or pollerito also constitutes a form of violence. These word choices reveal deeply seated ageist, classist and racist tendencies, and inscribe criminal behaviours as inherent to people. The discourse of mobility on the border has become weaponised. Let us not allow it to continue being yet another form of violence against the people of the US-Mexico border — and in particular, against its children.

Gabriella Sanchez is research fellow at the Migration Policy Centre in the European University Institute and leads the Migrant Smuggling Observatory. Her ethnographic work has primarily explored the social organisation of migrant smuggling through participatory research conducted alongside and by smuggling facilitators themselves across the Americas, the Middle East, North Africa, Australia and Europe.Email: gabriella.sanchez@eui.eu. 
Debate: 'It is important and necessary to make clear distinctions between (irregular) migrants, refugees and trafficked persons' 


\title{
Migrants, Irregular Migrants, or (Irregular) Migrants?
}

\author{
Katharine T. Weatherhead
}

\section{Response to the ATR Debate Proposition: 'It is important and necessary to make clear distinctions between (irregular) migrants, refugees and trafficked persons.' ${ }^{1}$}

Please cite this article as: K T Weatherhead, 'Migrants, Irregular Migrants, or (Irregular) Migrants?', Anti-Trafficking Review, issue 11, 2018, pp. 121-124, www.antitraffickingreview.org

Upon first reading this issue's debate proposition, I was struck by its structure rather than its content. Its content is subject to lively discussions among scholars, practitioners, and policy-makers, as attested to by other contributions in this issue of the journal. Its curious structure, though, raises issues that merit articulation. In what follows, I briefly problematise the bracketing of the word 'irregular' in the debate proposition. What the brackets do is prompt an additional question: migrants, irregular migrants, or (irregular) migrants?

To consider the significance of bracketed text, it is helpful to draw upon the work of Annelise Riles, in which she examines the negotiation of documents at United Nations conferences. ${ }^{2}$ In Riles' analysis, the document under negotiation is not yet an object but is instead a gathering of intentions awaiting consolidation, a focus of thought. ${ }^{3}$ She writes:

"Consensus" among states was manifest in a specific form-that is, in the form of the "clean" and "tight" text, the text without brackets, the text that had not been watered down but rather made strong,

\footnotetext{
1 I am grateful to the journal editors for their helpful comments and suggestions.

2 A Riles, 'Infinity within the Brackets', American Ethnologist, vol. 25, no. 3, 1998, pp. 378-398.

3 Ibid., p. 389.
}

This is an open-access article distributed under the terms of the Creative Commons Attribution License (CC-BY). Under the CC-BY license, the public is free to share, adapt, and make commercial use of the work. Users must always give proper attribution to the authors and the Anti-Trafficking Review. 
precise statements. If the parties reached consensus, the brackets were removed, to the satisfaction and pleasure of all. If any one state refused to agree, however, the brackets remained and people said that the text was "unreadable."

The bracketed text, therefore, is not a 'clean' text. It contains an element of fragility and imprecision.

From this perspective, what was once inconspicuous punctuation in the debate proposition becomes noteworthy. Far from separating the term 'irregular' from its seemingly more crucial context, the brackets draw attention to, invite deliberation on, and compel resolution of the status of irregular as a label.

The category of migrant can be variously defined even within one country, ${ }^{5}$ but in an international context, it broadly applies to people who have moved from one state to another state. It is often qualified to indicate several subcategories of migrant. Irregular migrant is one such sub-category which usually refers to people who have travelled across state borders without authorisation and/or who, even after travelling with authorisation, have stayed in a state against the terms of that authorisation. ${ }^{6}$ Writing '(irregular) migrant', with the brackets, adds ambiguity to the distinction between category and subcategory.

I limit myself to two interpretations of the brackets which respond to this ambiguity. One interpretation emphasises openness. In this interpretation, writing '(irregular) migrant' indicates an awareness of two groups- the broad category of migrant and the sub-category of irregular migrant-which are closely connected but nonetheless different. There is accordingly a freedom to acknowledge their entanglement or to treat them as particular.

4 Ibid.

5 On the United Kingdom, see: B Anderson and S Blinder, 'Who Counts as a Migrant? Definitions and their consequences', Migration Observatory Briefing, University of Oxford, 2017, $5^{\text {th }}$ revision, retrieved 13 December 2017, http:// www.migrationobservatory.ox.ac.uk/wp-content/uploads/2016/04/BriefingWho_Counts_Migrant.pdf.

6 See, for example, the definition of migrant workers in an irregular situation in UN General Assembly, International Convention on the Protection of the Rights of All Migrant Workers and Members of Their Families, 18 December 1990, Article 5. 
Debate drawing upon this first interpretation might exhibit fluidity in how the two categories are used. On the one hand, discussants could acknowledge their entangled nature and thereby disrupt narratives which represent categorisations as self-evident. On the other hand, they might treat them as particular and thereby reinforce the very possibility of categorisation. Either approach is permitted under an open interpretation of the brackets. A consequence is that the fragility and imprecision of the bracketed text continues. The debate proposition is 'unreadable', the parameters are not set, and the ensuing dialogue may be at cross-purposes.

A contrasting, 'cleaner' interpretation emphasises closure. In this interpretation, the brackets dictate a specific reading of the term migrant, which is other than its basic meaning. They instruct 'migrant' to be read as 'irregular migrant', hinting at the equivalence of the terms in this context. A closed interpretation of the brackets narrows the discussion to whether it is important and necessary to make clear distinctions between irregular migrants, refugees, and trafficked persons.

Debate that draws upon this second interpretation counteracts the unreadability of the bracketed text by removing the brackets. The discussion parameters are set. However, equating migrant with irregular migrant risks perpetuating negative connotations of the former term in public discourse. In addition, this approach of a 'tight' text exacerbates the tendency for shorthand to obscure the untidy reality of interactions between people and processes producing a migration status - a status which is not always clear-cut itself. The reductive label of irregular migrant may contribute to the stigmatisation of persons without regular migration status, because it conceals the complexities of each individual's lived experiences.

My point is that there are debates to be had within debates; that the migration field is replete with conceptual wrangling and requires careful navigation. ${ }^{7}$ Concepts direct thought in different ways and have consequences for understanding the varied forms of migration. ${ }^{8}$ It is important and necessary

For an examination of international law to carefully define the term 'mixed migration', see: M Sharpe, 'Mixed Up: International law and the meaning(s) of “mixed migration”, Refugee Survey Quarterly, vol. 37, issue 1, 2018, pp. 116-138.

8 D Turton, 'Conceptualising Forced Migration', Refugee Studies Centre Working Paper No. 12, University of Oxford, 2003, pp. 2-7, retrieved 13 December 2017, https://www.rsc.ox.ac.uk/files/files-1/wp12-conceptualising-forcedmigration-2003.pdf. 
to be attentive to what is bracketed in order to develop a critical awareness of the contestability of categories, the unboundedness of the bounded.

Katharine T. Weatherhead is a $\mathrm{PhD}$ candidate based in the School of Law at Queen Mary University of London. In 2014, she was awarded an MA (Hons) in International Relations and Law from the University of Edinburgh. In 2016, she received an MSc in Refugee and Forced Migration Studies from the University of Oxford. Drawing from the disciplines of both International Relations and Law, Katharine's doctoral research examines the creation of legal knowledge among migrants in the European Union. Email: k.t.weatherhead@qmul.ac.uk. 


\title{
The Antics of Semantics in International Law
}

\author{
Marika McAdam
}

\section{Response to the ATR Debate Proposition: 'It is important and necessary to make clear distinctions between (irregular) migrants, refugees and trafficked persons.'}

Please cite this article as: M McAdam, 'The Antics of Semantics in International Law', Anti-Trafficking Review, issue 11, 2018, pp. 125-128, www.antitraffickingreview.org

Whether a person is given a loaded label like 'irregular' migrant, refugee or trafficked person, can make the difference between arrest and protection, or between deportation and asylum, or between return to an uncertain fate and assistance for a decent life. In short, the distinctions we make in the language of international law may mean the difference between life and death.

But the categories we use are not mutually exclusive. Take for instance, a migrant who pays to be smuggled and is tortured to extort money from his parents before being delivered to his destination. He is not necessarily a victim of trafficking, but is a migrant who has experienced an aggravated form of smuggling and may have significant protection and assistance needs as a result. ${ }^{1}$ In contrast, at the point that a victim of trafficking is identified, he may not have suffered as much at the hands of his traffickers. The labels 'trafficked' or 'smuggled' then, may not speak to the specific plight or needs of the individuals they attach to. Similarly, the fact that a refugee falls victim to traffickers does not mean that she does not also have a well-founded fear of persecution, and the fact that a person pays to be smuggled does not mean that he is not a victim of trafficking or in search of asylum. Indeed, one situation may be a cause or result of another.

1 See article 6(3) of UN General Assembly, Protocol against the Smuggling of Migrants by Land, Sea and Air, Supplementing the United Nations Convention against Transnational Organized Crime, 15 November 2000.

This is an open-access article distributed under the terms of the Creative Commons Attribution License (CC-BY). Under the CC-BY license, the public is free to share, adapt, and make commercial use of the work. Users must always give proper attribution to the authors and the Anti-Trafficking Review. 
The value of these labels to those who ascribe them and those they are ascribed to comes from what is done with them. As it is, a smuggled migrant may be criminalised for that fact, contrary to international law, and be deported notwithstanding a valid claim not to be. A victim of trafficking may gain more from being considered an exploited migrant labourer, who can seek a civil remedy and receive the wages owed to her, than from being recognised as a victim and made to wait for months in a trafficking shelter for a criminal process which possibly does not result in any compensation. ${ }^{2}$ It might not matter to a refugee that she is not recognised as such under the 1951 Refugees Convention if she is spared from refoulement as a victim of trafficking or a survivor of torture.

Effort needs to be invested then not in forcing distinctions between terms, but in responsibly applying them so that people who fall-or rather, are placed-into these categories do not miss out on entitlements because of or despite the labels applied to them. Success in this endeavour does not lie in the extent to which tidy distinctions are cleaved between concepts, but in the extent to which the full raft of international treaties is leveraged for the benefit of those in need of assistance and protection.

Doing otherwise suggests that there may be disingenuous approaches taken to what should be good faith interpretations of international law. ${ }^{3}$ Those who would rather approach victims of trafficking as smuggled migrants may be seeking to take advantage of a lax understanding and application of the framework protecting smuggled migrants. And those who fixate, for instance, on disassociating 'refugees' from what it is to be a 'migrant' overlook the chaotic circumstances of individuals and the common shifts in factors driving human mobility. ${ }^{4}$ This 'one or the other' agenda fuels a destructive turf war over topic-territory that ultimately may come at the cost of meaningful

2 Based on the author's own consultations with practitioners. See also: A Testa and E Taylor-Nicholson, Enabling Access to Justice: A CSO perspective on the challenges of realising the rights of South Asian migrants in the Middle East, Global Alliance Against Traffic in Women, Bangkok, 2017, p. 25, retrieved 4 June 2018, http:/ /www.gaatw.org/resources/publications/919-enabling-access-to-justice-a-csoperspective-on-the-challenges-of-realising-the-rights-of-south-asian-migrants-inthe-middle-east.

3 Vienna Convention of the Law of Treaties 1969, Article 31.

4 See for instance: J Carling, 'Refugee Advocacy and the Meaning of "Migrants", PRIO Policy Brief 2, PRIO, Oslo, 2017. 
protection of the people caught in its crossfire. It also signals to those who work at the frontline and along the fault lines to respond to urgent human needs and who do not have the time, capacity or incentive to scrutinise and unravel the interconnected threads of international law, that 'migrant' is a label not worth having. To play tug-of-war over classifications is to treat as simple what is unquestionably complicated, and to surrender to political spin that would have us believe that 'irregular' migrants cannot also be victims of trafficking or that they have lesser rights to seek asylum than others.

When all is said and done though, there is one label that must be applied even when all others are tussled over, intellectualised, hierarchised and brutalised. Whether a refugee, trafficked person, smuggled migrant, 'irregular' migrant or formerly known as 'illegal' migrant, stateless, female, male, transgender, intersex, gay, straight or still experimenting and undecided-the category to which every person belongs, is this: human.

Human rights attach to us on the basis of our inherent dignity as human beings. These rights are not diminished when another label is ascribed to the human at issue, or by the circumstance she has placed herself in or has been placed in by others. Sometimes, in some contexts, clear distinctions can be made between migrants, refugees and trafficked persons. But when distinctions cannot be made on the basis of facts at hand, they should not be forced on the basis of the agendas at issue. In the current geopolitical climate, the architecture of international law is at risk of crumbling under the weight of disrespect and indifference, resulting in international organisations wielding semantics as a weapon in the fight for dwindling funds. The framework of human rights law is a casualty we cannot afford. Whatever labels may be ascribed to us, when it comes to human rights, it is important and necessary that we remain indistinguishable. ${ }^{5}$

5 Some of the ideas expressed in this article are more fully explored in: M McAdam, 'What's in a Name? Victim naming and blaming in rights-based distinctions between human trafficking and migrant smuggling', International Human Rights Law Review, vol. 4, issue 1, 2015, pp. 1-32. 
Marika McAdam is an independent legal consultant, scholar and adviser who has worked with UNODC, IOM, OHCHR, Chatham House, and the Nexus Institute, among others. She has delivered training to law enforcers and prosecutors; advised barristers, senators and legislators; and researched the challenges of implementing international law in national practice in Africa, Europe, Latin America, the Middle East and the South Caucasus. Marika has written book chapters and journal articles about migrant smuggling, human trafficking, migration and human rights, and their intersections, and has recently published a book titled Freedom from Religion and Human Rights Law (Routledge, 2017).Email: marika_mcadam@yahoo.com.au. 


\title{
Words Matter. But Rights Matter More
}

\author{
Pia Oberoi
}

\section{Response to the ATR Debate Proposition: 'It is important and necessary to make clear distinctions between (irregular) migrants, refugees and trafficked persons.'}

Please cite this article as: P Oberoi, 'Words Matter. But Rights Matter More', Anti-Trafficking Review, issue 11, 2018, pp. 129-132, www.antitraffickingreview .org

The international community has recently taken steps to agree two intergovernmental compacts, which together are intended to revitalise the global governance of migration and asylum. ${ }^{1}$ The Global Compact on Refugees seeks to strengthen international cooperation on the refugee regime, while the Global Compact for Safe, Regular and Orderly Migration aims to establish principles, commitments and understandings among Member States regarding international migration in all its dimensions. The compacts have been brought into existence against a backdrop of widespread and increasingly systematic human rights violations committed against migrants by state officials, traffickers and other criminals, and leading to what has been called 'one of the greatest human tragedies of our time'. ${ }^{2}$ At the same time, the very bifurcation of the compacts into two 'separate, distinct and independent' 3 agreements rests on a set of assumptions that could distort rather than illuminate the complex issue of contemporary human mobility.

1 See: UN General Assembly, New York Declaration for Refugees and Migrants, 19 September 2016.

2 Report of the Special Rapporteur on torture and other cruel, inhuman degrading treatment or punishment, A/HRC/37/50, para. 64(a).

3 Modalities for the intergovernmental negotiations of the global compact for safe, regular and orderly migration, A/RES/71/280.

This is an open-access article distributed under the terms of the Creative Commons Attribution License (CC-BY). Under the CC-BY license, the public is free to share, adapt, and make commercial use of the work. Users must always give proper attribution to the authors and the Anti-Trafficking Review. 
One such underlying premise is that refugees are not migrants. While it is easy to agree with the proposition that refugees are refugees, i.e. people who have left their homes for fear of conflict or persecution, it is less straightforward to say that they are 'not migrants' for the simple reason that there is no universal legal understanding of the scope and content of the term 'migrant'. ${ }^{4}$ Further, the issues of identification, referrals and assistance of trafficked persons appear in both compacts, leading to additional confusion about whether trafficked persons are also considered refugees and/or 'migrants', and how the distinction being made between the two latter categories affects the protection space in the context of trafficking. And while the focus of the two compacts is specifically on cross-border movements, it is important to recall that trafficked persons often do not cross international borders. ${ }^{5}$

The bifurcation into oppositional categories of 'refugees' versus 'migrants' is further complicated by the complex human rights protection needs evident today. The United Nations Secretary-General has highlighted the plight of 'migrants in desperate situations, who are ineligible for refugee protection, yet who are particularly at risk.' A recent UN inter-agency initiative spearheaded by OHCHR notes that, 'where migrants fall outside the specific legal category

4 In the absence of a specific legal definition, the Office of the High Commissioner for Human Rights (OHCHR) simply understands an international migrant as 'any person who is outside a State of which they are a citizen or national, or, in the case of a stateless person, their State of birth or habitual residence'. This usage is without prejudice to the protection regimes that exist under international law for specific legal categories of non-nationals, including refugees, stateless persons, trafficked persons and migrant workers. See for example, Office of the High Commissioner for Human Rights and Global Migration Group, Principles and Guidelines, Supported by Practical Guidance, on the Human Rights Protection of Migrants in Vulnerable Situations, OHCHR/GMG, Geneva, 2018, retrieved 15 August 2018, https://www.ohchr.org/Documents/Issues/Migration/ PrinciplesAndGuidelines.pdf.

5 United Nations Office on Drugs and Crime, Global Report on Trafficking in Persons 2016, United Nations, Vienna, 2016, p. 9.

6 See para 47 of the Secretary-General's report Making Migration Work for All (A/ 72/643) available at https://refugeesmigrants.un.org/sites/default/files/ sg_report_en.pdf. In an earlier report, the Secretary-General also pointed out that 'notwithstanding the gradual expansion of refugee protection, many people are compelled to leave their homes for reasons that do not fall into the refugee definition' (A/70/59, para. 18). 
of "refugee", it may be especially important to ensure that their human rights are respected, protected and fulfilled. Some migrants will need specific protection because of the situations they left behind, the circumstances in which they travel or the conditions they face on arrival, or because of personal characteristics such as their age, gender identity, disability or health status. ${ }^{7}$ The emerging concept of 'migrants in vulnerable situations' makes clear that this vulnerability is not the result of a personal deficiency on the part of the migrant, and that being 'vulnerable' does not divest a person of agency or even resilience. 'Migrants in vulnerable situations' are people on the move in specific circumstances who are unable to effectively enjoy their human rights due to situations that are often-or usually_imposed on them by means of law, policy and practice. While these situations will not entitle them to refugee status, such migrants are at increased risk of human rights violations and abuse, and, consequently, are entitled to call on a duty bearer's heightened duty of care. ${ }^{8}$

Accordingly, my contention in response to the proposition of this debate, is that it is important and necessary to ensure that, regardless of categorisations, every person on the move is afforded the protection to which they are entitled under international law by virtue of their unique and individual circumstances. Such protection can be found in international refugee or human rights law, or in related standards including international labour or criminal law. The complex motivations for movement and the fluid, dangerous, long and multidirectional journeys taken by people on the move today require nuanced, contextualised and protection-sensitive responses. However, the necessity and suitability of defining this protection in antagonistic or oppositional terms is less clear and has even proven harmful; human rights protection is not a zero sum game. As the Global Compacts come into operation, it is important to challenge the assumption that there exists a finite amount of protection available only to those considered 'most deserving'.

International law clearly defines a refugee and is similarly specific in the definition of a trafficked person. The Global Compacts must build on these legally established and binding frameworks to ensure that the protection of the rights of refugees and the rights of trafficked persons are improved, not diminished. In addition, we can do better for migrants than defining them only as 'not refugees' or 'not victims of trafficking', especially when their need for human rights protection is often no less acute.

OHCHR and Global Migration Group, p. 1.

8 See resolution A/HRC/RES/35/17 of the Human Rights Council (June 2017). 
Migrants can be highly vulnerable to the most severe human rights violations, including arbitrary detention, collective expulsions, torture, family separation, denial of access to critical healthcare, and xenophobic violence, particularly when they are in irregular situations. This vulnerability is largely the result of specific migration governance paradigms, such as criminalisation of migration and mandatory or indefinite detention regimes, externalisation and securitisation of borders, a lack of safe and regular pathways, and entrenched precarity in labour migration. ' These responses to migration often make refugees and trafficked persons vulnerable to harm as well. States and other actors must reconsider a single-minded focus on distinctions, particularly where this may result in restricting the rights of those considered 'less deserving'. Instead, migration governance must prioritise and guarantee the universal protection of human rights law for all people on the move.

Pia Oberoi is Advisor on Migration and Human Rights at the Office of the United Nations High Commissioner for Human Rights where she heads the OHCHR Migration Team and leads OHCHR's global programme of work on policy and legal issues related to the intersections between migration and human rights. Prior to this, Pia led the migrant rights work of Amnesty International's International Secretariat. She holds a DPhil in International Relations from St Antony's College, Oxford University. This article is written in her personal capacity and the views expressed herein do not necessarily represent the views of the United Nations. Email: POberoi@ohchr.org.

9 See, in addition, the findings of the UN Special Rapporteur on Torture that 'The primary cause for the massive abuse suffered by migrants in all regions of the world ... is neither migration itself, nor organized crime, or the corruption of individual officials, but the growing tendency of States to base their official migration policies and practices on deterrence, criminalization and discrimination, rather than protection, human rights and non-discrimination.' (A/HRC/37/50, para. 64(d).) 


\title{
Call Me by My Name
}

\author{
Sarah Elliott
}

\section{Response to the ATR Debate Proposition: 'It is important and necessary to make clear distinctions between (irregular) migrants, refugees and trafficked persons.'}

Please cite this article as: S Elliott, 'Call Me by My Name', Anti-Trafficking Review, issue 11, 2018, pp. 133-136, www.antitraffickingreview.org

The image of rubber dinghies densely packed with people floating precariously in the Mediterranean Sea has become a symbol of our times. Among those in peril are persons who may have fled conflict, others who have left poverty and many who have suffered exploitation en route. Upon arrival, states are obliged to meet their immediate needs and to determine for what reasons they came, thereby identifying their rights under international and domestic law.

It has been argued that categorical distinctions between these persons can lead to a 'hierarchy' of assistance excluding those who do not fit 'neatly' into the definitions of refugee or trafficked person, but who still need help. In response, some prefer to use the term 'migrant' as a catch-all phrase for all persons who have crossed an international border. They argue that this usage not only better reflects the complex and interlinked drivers, root causes and experiences of human mobility and displacement today, but also avoids pitting refugees, migrants or trafficked persons against one another. ${ }^{1}$

Whilst accepting that assistance gaps for (irregular) migrants do exist, I contend that summarily referring to refugees or trafficked persons as 'migrants' is not the best solution. In making the argument for maintaining distinct legal categories, it

1 See, for example, J Carling, 'Refugee Advocacy and the Meaning of "Migrants", PRIO Policy Brief 2, Oslo, 2017, retrieved 2 January 2018, https://www.prio.org/ Publications $/$ Publication $/ \mathrm{P}_{\mathrm{x}}=10471$.

This is an open-access article distributed under the terms of the Creative Commons Attribution License (CC-BY). Under the CC-BY license, the public is free to share, adapt, and make commercial use of the work. Users must always give proper attribution to the authors and the Anti-Trafficking Review. 
is useful to begin by reflecting upon the reasons for such distinctions and upon the policies and practices that have evolved in response to, and in support of, their usage.

Nomenclature helps us sort through everyday language and ensures that, in some cases, legal consequences attach to words. At various points in history, a critical mass of states decided that the experience of particular individuals required an international response, distinguished them by a specific terminology and defined a detailed set of rules for their help and protection. The term 'refugee' exists because the international community recognised that some persons should not be returned to a place where their life or freedom is threatened. Unable to return home, refugees were granted a bundle of progressively accrued rights to enable them to rebuild their lives where they fled.

In law, a person is a refugee as soon as the elements in Article 1(a) of the 1951 Convention Relating to the Status of Refugees, interpreted alongside the 1967 Protocol Relating to the Status of Refugees, or the definitions found in regional refugee instruments, are met. Not identifying refugees as stipulated by these conventions, risks depriving them of the protections and freedoms that the international community decided to grant them. This is why, for over sixty years, the United Nations High Commissioner for Refugees has supported states to understand who refugees are, develop fair and efficient refugee status determination procedures, and adapt refugee protection tools to different contexts.

Developing an international definition of 'trafficking in persons' responded to another compelling global need. States sought to more effectively counter the burgeoning exploitation of people through deception or coercion, and to identify and support those affected. ${ }^{2}$ Since 2000, 173 states $^{3}$ have ratified or acceded to the Protocol to Prevent, Suppress and Punish Trafficking in Persons, Especially Women and Children ${ }^{4}$ and a majority have adopted anti-trafficking laws that generally reflect the internationally agreed definition. ${ }^{5}$ This definition, albeit imperfect, has also led

2 A Gallagher, The International Law of Human Trafficking, Cambridge University Press, Cambridge, 2010, p. 16.

3 UN Treaty Collection, retrieved 10 June 2018, https://treaties.un.org/Pages/ ViewDetails.aspx?src=IND\&mtdsg_no=XVIII-12-a\&chapter=18\&lang=en.

4 UN General Assembly, Protocol to Prevent, Suppress and Punish Trafficking in Persons, Especially Women and Children, Supplementing the United Nations Convention against Transnational Organized Crime, 15 November 2000.

5 Gallagher, p. 42. 
to the development of hundreds of international, regional and national protection mechanisms for trafficked persons.

These are clear reasons why legal categories should be maintained, and the distinctions between them respected.

While the term (irregular) migrant remains undefined in international law, migrants are people and, as such, do benefit from international human rights law regardless of their migration status. In cases where migrants are also workers, children, stateless persons, victims of torture or persons with disabilities, most states are obliged to provide additional support in accordance with specific international human rights instruments related to these categories. ${ }^{6}$ Unlike in the case of refugees, however, states are seldom required to allow (irregular) migrants to stay on their territories beyond the time required for the determination of their legal status. Moreover, no specific and internationally recognised community of practice exists to identify and provide assistance to (irregular) migrants in need of help, in contrast with the support networks available to both refugees and trafficked persons.

The real question, then, is how can clear and necessary distinctions between categories of people on the move be maintained, without a trade-off of rights to the disadvantage of (irregular) migrants? Currently, (irregular) migrants are too often deported to their home countries without sufficient consideration for other options that may be available to them; these deportations frequently involve the use of force or other violations of human rights. It is imperative, therefore, that the international community devise safe, fair and comprehensive systems for determining and implementing the proper treatment of irregular migrants, as a complement to, rather than in competition with, refugee status determination systems.

6 See, for example, the 1954 Convention Relating to the Status of Stateless Persons, the 1984 Convention Against Torture and other Cruel, Inbuman or Degrading Treatment or Punishment, the 1989 Convention on the Rights of the Child and the 1990 International Convention on the Protection of the Rights of All Migrant Workers and Members of Their Families. 
In addition to the forthcoming Global Compact for Refugees, and the Global Compact for Safe, Orderly and Regular Migration, international and regional entities have been working on new, globally applicable tools to guide states in how best to respond to the challenges of human cross-border mobility and displacement, in the spirit of international responsibility and cooperation. For example, the Office of the High Commissioner for Human Rights and the Global Migration Group recently published Principles and Guidelines on the Human Rights of Migrants in Vulnerable Situations, ${ }^{7}$ and the International Organization for Migration is developing a handbook that will support stakeholders in how to identify and assist vulnerable migrants in practice. Further, the Organization for Security and Cooperation in Europe is in the process of updating its seminal Handbook on National Referral Mechanisms (for victims of human trafficking), ${ }^{8}$ including a new chapter on immigration and asylum considerations.

However, only by ensuring that these initiatives provide more rather than less precision, and continue to respect existing legal categories designed to effectively meet the real needs of people on the move, can we forge ahead into a new paradigm of international agreement about how states should manage their borders, and respond to the needs of those crossing them.

Sarah Elliott is a legal officer at the UNHCR. She specialises in the fields of refugee law, migration studies and international criminal law, and the application of these frameworks to human trafficking and migrant smuggling. Her previous work at the UNHCR included implementing counter-trafficking programmes in partnership with the UNODC, UNICEF, UNFPA and IOM in Sudan. She was also instrumental in developing institutional policy guidance on counter-trafficking prevention and response initiatives within UNHCR's Asylum and Migration Unit, Division of International Protection. The views expressed here are the author's and do not represent the position of the UNHCR. Email: elliotts@unhcr.org.

7 Office of the High Commissioner for Human Rights and Global Migration Group, Principles and Guidelines, Supported by Practical Guidance, on the Human Rights Protection of Migrants in Vulnerable Situations, OHCHR/GMG, Geneva, 2018, retrieved 15 August 2018, https://www.ohchr.org/Documents/Issues/Migration/ PrinciplesAndGuidelines.pdf.

8 Organization for Security and Cooperation in Europe, National Referral MechanismsJoining Efforts to Protect the Rights of Trafficking Persons: A practical handbook, OSCE, Warsaw, 2004. 


\section{ANTI-TRAFFICKING REVIEW}

\section{Guidelines for Contributors}

We welcome submissions from a diverse range of actors, including academics, practitioners, trafficked persons and advocates. The Anti-Trafficking Review particularly welcomes contributions from those with direct experiences and insights to share.

The Anti-Trafficking Review is aimed at a wide readership. It therefore encourages submissions that are in clear, jargon-free English with appropriate but not excessive citation.

Articles should be previously unpublished and should not be under consideration for publication elsewhere. All articles go through a rigorous double-blind peer review process.

Please refer to the journal's website (www.antitraffickingreview.org) for the journal's full style guide and guidelines for contributors.



GLOBAL ALLIANCE AGAINST TRAFFIC IN WOMEN

P.O. Box 36, Bangkok Noi Post Office 10700 Bangkok, Thailand

Website: www.antitraffickingreview.org 


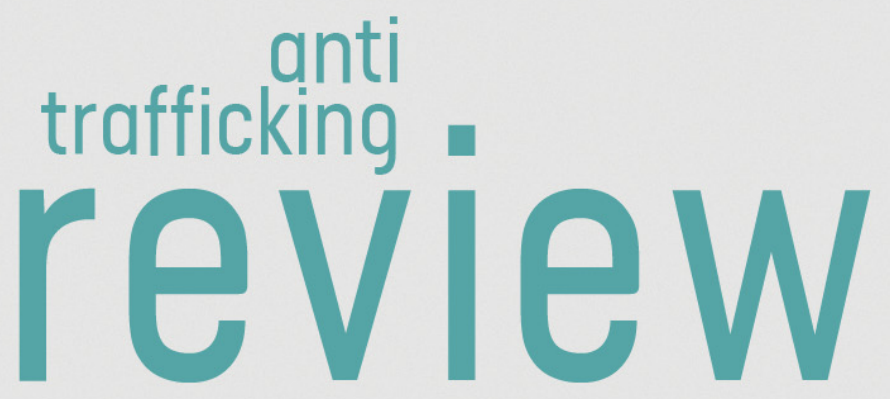

The Anti-Trafficking Review promotes a human rights-based approach to anti-trafficking. It explores trafficking in its broader context including gender analyses and intersections with labour and migrant rights. It offers an outlet and space for dialogue between academics, practitioners, trafficked persons and advocates seeking to communicate new ideas and findings to those working for and with trafficked persons.

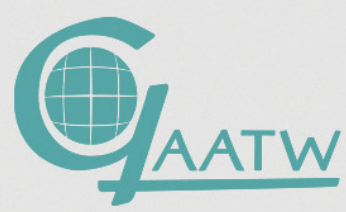

Global Alliance Against Traffic in Women www.antitraffickingreview.org 